\title{
弁ばね用高強度 $\mathrm{Si}-\mathrm{Cr}$ 鋼オイルテンパー線の研究*
}

\author{
高強度線の耐久性に関する調査研究委員会 \\ 弁ばね用ワーキンググループ

\section{Studies on High-Strength Oil-Tempered Chromium-Silicon Alloy Steel Wire for Valve Springs}

\author{
Valve Spring Working Group \\ Research Comittee on Durability of High-Strength Steel Wire
}

\begin{abstract}
It is afraid that increasing the strength of oil-tempered steel wire for valve springs might result in a loss of workability, fatigue strength and creep resisitance. The committee, therefore, investigated the effects of the chemical composition, wire strength, annealing condition, residual stress induced by shot peening, etc., on the mechanical properties of wires and valve springs.

The material used for this study was made of the conventional oil-tempered high tension steel wire (JIS $\mathrm{G}$ 3566) by increasing its carbon level to the JIS-prescribed upper limit and adding some vanadium. It was then made into two specimens by tempering to tensile strength levels of 2,000 and 2,100MPa, respectively. For the purpose of comparison, two other specimens were made of conventional oil-tempered wire(JIS G 3566 ) by tempering to strength levels of 1,900 and $2,000 \mathrm{MPa}$, respectively.

In conclusion, high-tension steel wire of this study has been found to possess equal workability with improved fatigue strength, and better creep resistance, when compared with the standard steel wire(JIS G 3566), thus demonstrating the superiority of high-tension steel wire for valve springs. To further improve fatigue strength and creep resistance, it has been found more important to make changes in chemical compositions, and to make further improvements in shot peening process and in other surface-treating technologies, rather than only increasing the tensile strength of the wire.
\end{abstract}

Key Words : Oil-tempered wire, Valve spring, Fatigue strength, Creep resistance, Workability, Annealing, Shot peening

\section{1.はじめに}

\section{1 高強度線の耐久性に関する調査研究事業の背景 と目的}

ばねの軽量化, 小型化, 高性能化を図るためには, 用い る材料の高強度化注) が必要であるが，最近，ますますその 要請が強まっている。1) 例えば, ばね技術研究会で行われた オイルテンパー線についての広範囲なアンケート調査の結 果でも,

（1）リテーナスプリング用など細径で弁ばね級の品質保 証を要するシリコンクロム鋼オイルテンパー線，（2）懸架 ばね用シリコンクロム鋼オイルテンパー線, 及び (3) 弁ば ね用シリコンクロム鋼オイルテンパー線の高強度化が強く 求められていることが確かめられた。 意に線の引張強さを高くすると, 以下に示すような幾つか の問題が生じて，おのずから高強度化に限界を生じる。す なわち，(1）加工性の低下。コイリング中の線に割れや折 損が生じやすくなり，また，ばねの形状，寸法のばらつき が増加する。

原稿受付 1994 年10月 6 日

*ばね技術研究会1994年度春季講演会にて発表
(2) じん性の低下。

（3）耐久性向上の頭打ち。とくにばねの疲労強度が線の 硬さや引張強さの上昇とともに高くなる，あるいは寿命が 伸びる，という傾向が小さくなる。

（4）対環境感受性の増加。水素脆性，応力腐食割れ，局 部腐食, 腐食疲労などに対する感受性が強まる。

加工性のうち変形能, または加工限界については, 従来, さほど大きな問題ではなかったが，強度の水準が限界まで 高まると，次第に重大な問題となることが予想される。し かも現在，適切な評価試験法は確立していない。

じん性や疲労特性に対して，鋼中の非金属介在物が著し い影響を及ぼすことは, よく知られて抢り, 介在物の低減 や形態制御による無害化が多大な努力により進んで来た。 また，表面性状の改善も注意梁く行なわれている。これら のことが高強度化を達成する要因であろう。ただし，成形 後のコイルばね素線に残存する大きな引張応力の緩和, 硬 さの上昇，より一層の表面平滑度向上などのために，表面 への圧縮残留応力付与法の十分な検討が必要と考えられる。

脚注）強度という表現は静的，動的の両方の意味が含まれるが，以下，本報告 では静的な意味で引張強さを高めたものに“高強度”という表現を用いる。 
このような背景から，平成 2 年 9 月に発足した高強度線 の耐久性に関する調査研究委員会は, 平成 3 年度から 3 年 間の予定で日本小型自動車振興会から機械工業振興資金の 補助を受けて, 細物用, 懸架用, 弁ばね用の各シリコンク ロム鋼系高強度オイルテンパー線についてそれぞれのワー キンググループを設け, 高強度線の実用化に際しての問題 点の抽出と JIS 規格の改正に反映させることを目的に共同 研究を行った。すなわち, 必要に応じて疲労特性, 切久き 感受性, 残留応力などの評価法, 測定法の標準化を図りな がら，高強度線及びばねの耐久性を中心とした諸特性を明 らかにするとともに, 高強度化に際しての問題点の把握と 対策の指針を求めた。

本報ではこの中で，弁ばね用ワーキンググループの共同 研究結果について報告する。

\section{2 弁ばね用高強度 $\mathrm{Si}-\mathrm{Cr}$ 鋼オイルテンパー線に関 する研究の概要 ${ }^{3}$}

内燃機関の弁ばねまたはこれに準じる冷間成形コイルば ねには，おもに，JIS G 3566 の弁ばね用シリコンクロム鋼オ イルテンパー線が用いられている。この規格に㧍ける引張 強さの規定は, 線径 $4 \mathrm{~mm}$ の場合, $1810 \mathrm{MPa} \sim 1960 \mathrm{MPa}$ で ある。しかし, 弁ばねの軽量化をめざして, 現在, 成分の 若干の変更あるいは特殊元素の添加を行って, 1 ランク強 度を高めた線の実用化が始まっているとともに，さらに， 線の高強度化が要望されている。

ところが，不用意に引張強さを高めた線を用いると，加 工性，じん性，耐久性などの低下，環境脆化感受性の増大 など，いくつかの問題が生じかねない。さらに，ばねの性 能は使用する線の特性によってのみ決まるものではなく, ばねの製造工程によっても大きく左右される。すでに，ば ねの高強度化は線の高強度に頼るのみでは達成できない強 度水準に達しており，ショットピーニングを含む全工程の 助けを必要とする。

このような背景を踏まえて，今回の弁ばね用ワーキング グループの共同研究においては，供試材として JIS G 3566 の SWOSC-V で成分の変更 (炭素量を規格の上限值とし, V を添加した。）を行い, 引張強さ $2100 \mathrm{MPa}$ と $2000 \mathrm{MPa}$ に才 イルテンパー処理した高強度鋼線, 及び, 引張強さ $2000 \mathrm{MPa}$ ，1900MPa にオイルテンパー処理したSWOSC-V の比較鋼の線を準備した。

なお，この高強度鋼線は現在実用化されている数種の材 料の中から入手しやすい材料を選定したものであり，特定 鋼種を将来の規格化の対象に推奨するものではない。

ここで，線の状態の試料については，引張り，ねじり, 硬さの各試験のほか, 脱炭層深さ, 旧オーステナイト結晶
粒度，非金属介在物，表面粗さ等の測定や表面きず観察を 行った。また，加工性試験としてノッチ曲げ試験，コイリ ング試験を, さらに, 疲労試験として中村式回転曲げ試験 を行った。コイルばねの状態では供試ばねの表層部特性 (残留応力分布, 硬さ分布, 表面粗さ) 測定, 加工ひずみ除 去試験，疲労試験，及び，締付け試験を行った。そして， これらの試験結果に及ぼす線の強度や低温焼なまし温度の 依存性, ショットピーニングの効果などを, 破面観察及び 残留応力の解析を行いながら，検討した。

なお，当ワーキンググループのメンバーは以下の通りで ある。

委員長

副委員長

金尾正雄

明治大学

委員 (リ-ダ-)

井上和政

委員 (サブリ-ダ-) 小泉義明

委員（サブリダー）川口康信

委員

○河合立芳

委員

海老原達郎

中里福和

玉井 豊

委員

委員

委員

初岡延泰

福岡 亮

児玉 勝

委員

委員

○高椋晴三 中田 秀

委員

委員

委員

委員

委員

委員

委員

委員

委員

○林 慶次

高橋憲一

○篠原竜二 小熊 仁

○江光一

土方直樹

伊沢佳伸

鈴木金属工業(侏)

日本発条(株)

鈴木金属工業(株)

(株)神戸製鋼所

新日本製鉄(株)

新日本製鉄(株)

住友金属工業(株)

トーアスチール(株)

サンコール(株)

サンコール(株)

神鋼鋼線工業(株)

住友電気工業(株)

住友電気工業(侏)

南海泉州製線鋼索(秼)

南海泉州製線鋼索(秼

加藤発条(侏)

加藤発条(株)

中央発條(株)

中央発條(侏)

中嶋和夫

(株)東郷製作所

村田発條(侏)

○は途中で交替した後の委員を示す。

\section{2. 供試材及び供試コイルばね}

\section{1 供試材}

今回の共同試験では JIS G 3566 の SWOSC-V 相当材に炭 素量を増加しバナジウムを添加した高強度鋼，及び比較鋼 として JIS G 3566 の SWOSC-V 相当材の 2 鋼種を用いた。 供試材の化学成分を 表 1 に示す。供試材の線径は $4 \mathrm{~mm}$ と し, 表 2 に示すように目標引張強さは高強度鋼は $2100 \mathrm{MPa}$, $2000 \mathrm{MPa}$ ，比較鋼は $2000 \mathrm{MPa} ， 1900 \mathrm{MPa}$ の各 2 水準，計 4 種類とした。以下，各々を $\mathrm{H} 21, \mathrm{H} 20, \mathrm{~S} 20, \mathrm{~S} 19$ 材と呼ぶ。

表 1 供試材の化学成分 (mass\%)

\begin{tabular}{c|c|c|c|c|c|c|c|c|c}
\hline 供試材 & $\mathrm{C}$ & $\mathrm{Si}$ & $\mathrm{Yn}$ & $\mathrm{P}$ & $\mathrm{S}$ & $\mathrm{Cu}$ & $\mathrm{Ni}$ & $\mathrm{Cr}$ & $\mathrm{V}$ \\
\hline 高強度龬 & 0.60 & 1.46 & 0.68 & 0.011 & 0.005 & 0.01 & 0.02 & 0.67 & 0.220 \\
\hline 比较 & 0.56 & 1.46 & 0.76 & 0.015 & 0.007 & 0.01 & 0.02 & 0.75 & 0.005 \\
\hline
\end{tabular}


表 2 供試材の引張強さ

\begin{tabular}{c|c|c|c}
\hline 供試材 & 呼称 & $\begin{array}{c}\text { 目標引張強さ } \\
(\mathbf{P a})\end{array}$ & $\begin{array}{c}\text { 引張強さ実湘值 } \\
(\mathbf{P a})\end{array}$ \\
\hline \multirow{2}{*}{ 高強度鎡 } & $\mathrm{H} 21$ & 2100 & 2060 \\
\cline { 2 - 4 } & $\mathrm{H} 20$ & 2000 & 2015 \\
\hline \multirow{2}{*}{ 比較 } & $\mathrm{S} 20$ & 2000 & 1972 \\
\cline { 2 - 4 } & $\mathrm{S} 19$ & 1900 & 1907 \\
\hline
\end{tabular}

表 3 供試ばね諸元

\begin{tabular}{l|l}
\hline 線 径 & $4.0 \mathrm{~mm}$ \\
\hline コイル平均径 & $22.8 \mathrm{~mm}$ \\
\hline 総巻き数 & 6.5 \\
\hline 有効巻き数 & 3.5 \\
\hline 自由高さ & $46 \mathrm{~mm}$ \\
\hline 密着高さ & $26 \mathrm{~mm}$ \\
\hline 密着応力 & $1393 \mathrm{MPa}$ \\
\hline ばね定数 & $60.5 \mathrm{~N} / \mathrm{mm}$ \\
\hline ピッチ角 & $8.2^{\circ}$ \\
\hline 巻き方向 & 右 \\
\hline
\end{tabular}

表 4 試験項目と分担

\begin{tabular}{l|l}
\hline \multicolumn{1}{c|}{ 項 } & \multicolumn{1}{|c}{ 会 } \\
\hline 供試 材 & $\mathrm{A} 、 \mathrm{D}$ 社 \\
\hline 材料試験 & $\mathrm{C} 、 \mathrm{D} 、 \mathrm{E} 、 \mathrm{~F}$ 社 \\
\hline ノッチ曲げ試験 & $\mathrm{D}$ 社 \\
\hline 回転曲げ㾉労試験 & $\mathrm{A} 、 \mathrm{C} 、 \mathrm{H} 、 \mathrm{I}$ 社 \\
\hline ばね成形 & $\mathrm{B}$ 社 \\
\hline 加工ひずみ除去試験 & $\mathrm{B}$ 社 \\
\hline ばねの疲労試験 & $\mathrm{G} 、 \mathrm{~K} 、 \mathrm{~L} 、 \mathrm{M} 、 \mathrm{~N}$ 社 \\
\hline ばねの締付け試験 & $\mathrm{B}$ 社 \\
\hline 破面解析 & $\mathrm{C} 、 \mathrm{D} 、 \mathrm{E} 、 \mathrm{~F}$ 社 \\
\hline
\end{tabular}

\section{2 供試コイルばね}

供試コイルばねの諸元を表 3 に，また，試験の主な担当 会社を表 4 に示す。さらに，ばねの主な製造工程を図 1 に示す。今回の共同研究ではコイリング後の低温焼なまし 条件, ショットピーニング条件によって 3 種類, 条件の違 うものを評価した。以下, それらを 1 次材, 2 次材, 3 次材 と呼ぶ。表 5 にこれらの低温焼なまし条件, ショットピー ニング条件及びアークハイト值を示す。ショットピーニン グ後の低温焼なまし ( 2 次) は $498 \mathrm{~K} \times 20 \mathrm{~min}$ 一定, また, セ ッチングは応力修正係数を含んで $1300 \mathrm{MPa}$ 一定とした。セ ッチング後の低温焼なましは行っていない。

なお，線はばねと同じ熱処理，ショットピーニング条件 とした。ただし，いずれの条件においてもアークハイト值 は線の方が大きくなっている。
[工程]<smiles>[Si]=C1C=CC=C1</smiles>

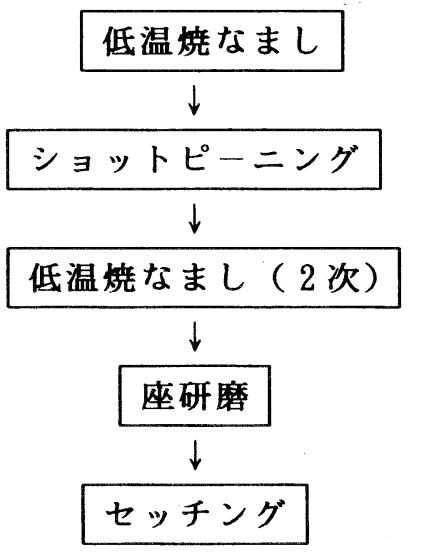

[条件]

2 本ピンコイリング $598 \mathrm{~K}, 698 \mathrm{~K} \times 25 \mathrm{~m}$ in シングル＆ダブル ショットピーニング $498 \mathrm{~K} \times 20 \mathrm{~min}$

1300YPa、1回

表 5 供試材の低温焼なまし，ショットピーニング条件

\begin{tabular}{|c|c|c|c|}
\hline 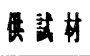 & 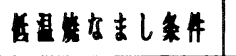 & ショタトピーニンク条代 & アークハイト筧 \\
\hline $12 甘$ & $698 \mathrm{~K} \times 25 \mathrm{~min}$ & $\begin{array}{l}\text { シンタル, 10.6カタトワイヤ } \\
47 \mathrm{~m} / \mathrm{s} \times 20 \mathrm{~min}\end{array}$ & $\begin{array}{l}: 0.35 \sim 0.36 \mathrm{mmA} \\
H a: 0.28 \sim 0.30 \mathrm{mmA}\end{array}$ \\
\hline 2 次 & $598 \mathrm{~K} \times 25 \mathrm{~m}$ in & $\begin{array}{l}\text { シンク, 10.6カ,トワイヤ- } \\
47 \mathrm{~m} / \mathrm{s} \times 20 \mathrm{~min}\end{array}$ & $\begin{array}{l}: 0.35 \sim 0.38 \mathrm{mmA} \\
\forall n: 0.28 \sim 0.29 \mathrm{mmA}\end{array}$ \\
\hline 3 次 & $598 \mathrm{~K} \times 25 \mathrm{~min}$ & $\begin{array}{l}\text { タフル } 0.8+60.4 \text { カトワイー } \\
0.8: 65 \mathrm{~m} / \mathrm{s} \times 20 \mathrm{~min} \\
0.4: 47 \mathrm{~m} / \mathrm{s} \times 20 \mathrm{~min}\end{array}$ & 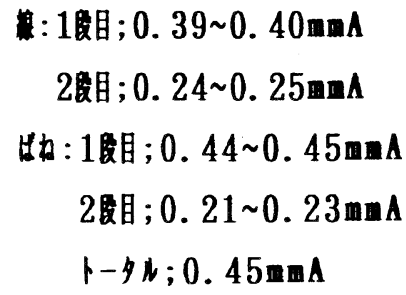 \\
\hline
\end{tabular}




\section{3. 試験方法}

\section{1 材料の基本的な試験項目と方法}

各供試材について，機械的性質とその低温焼なましによ る変化を調査した。

以下に各試験項目とその方法について述べる。

\subsection{1 引張試験法}

引張試験機を用いて荷重一伸び曲線を求めた後, 引張強 さ $\sigma_{B}, 0.2 \%$ 耐力 $\sigma_{0.2}, 0.05 \%$ 耐力 $\sigma_{0.05}$ 及び縦弾性係数 $E$ を 算出した。また, 破断後の試験片について伸び $\delta$, 絞り $\phi$ を 測定した。表 6 にその試験条件を示す。

\subsection{2 ねじり試験法}

ねじり試験機を用いてトルクー回転角曲線を求め, ねじ り強さ $\tau_{B}, 0.3 \%$ 耐力 $\tau_{0.3}, 0.03 \%$ 耐力 $\tau_{0.03}$ 及び横弾性係数 $G$ を算出した。また，ねじり回数の試験は，一定にねじり， 破断するまでのねじり回数 $T n$ を測定した。表 7 にその試 験条件を示す。

\subsection{3 硬さ試験法}

As OT (オイルテンパーのまま) 及び低温焼なまし後の線 表 6 引張試験法及び条件

\begin{tabular}{l|l}
\hline 試験機 & 島津製 $490 \mathrm{kN}$ インストロン型 \\
\hline 引張速度 & 降伏点まで $29 \mathrm{~N} / \mathrm{mm}^{2} / \mathrm{s}(8 \mathrm{~mm} / \mathrm{min})$ \\
& 降伏点以降 $25 \% / \mathrm{min}(67.5 \mathrm{~mm} / \mathrm{min})$ \\
\hline チャック間距離 & 約 $270 \mathrm{~mm}$ \\
\hline 標点距離 & $200 \mathrm{~mm}$ \\
\hline
\end{tabular}

表 7 ねじり試験法及び条件

\begin{tabular}{l|l}
\hline ねじり試験機 & 島津製 REP-50型 \\
\hline ねじり速度 & $1 \mathrm{rpm}(6.28 \mathrm{rad} / \mathrm{min})$ \\
\hline チャック間距離 & $400 \mathrm{~mm}(100 \mathrm{~d})$ \\
\hline 記録方法 & トルーねじり角自動記録 \\
\hline トルクレンジ & $49 \mathrm{~N} \cdot \mathrm{m}$ \\
\hline
\end{tabular}

表 8 硬さ試験法及び条件

\begin{tabular}{l|l}
\hline 試験機 & ビッカース硬さ試験機 \\
\hline 荷重 & $98 \mathrm{~N}$ \\
\hline 測定箇所 & 横断面 \\
\hline 測定点 & 9 点 (表層から深さ $0.3 \mathrm{~mm}$ 位置 4 点, \\
& 中間 $\mathrm{d} / 4$ 部 4 点, 中心 $\mathrm{d} / 2$ 部 1 点 $)$ \\
& (ただし, 結果は平均值で表示) \\
\hline
\end{tabular}

\begin{tabular}{|c|c|c|c|}
\hline 装置 & 理学電機零 & \multicolumn{2}{|c|}{ R A D - II A } \\
\hline $\mathrm{X}$ 線管球 & \multicolumn{3}{|c|}{ Yo（桛トフォーカス） } \\
\hline フィルター & \multicolumn{3}{|l|}{$\mathrm{Zr}$} \\
\hline 管電压 & $40 \mathrm{kV}$ & 管電流 & $25 \mathrm{~mA}$ \\
\hline スキャンスピード & $1^{\circ} / \min$ & チャートスピート & $10 \mathrm{~mm} / \mathrm{m}$ in \\
\hline フルスケーN & $8000 \mathrm{C} / \mathrm{s}$ & 時定数 & $1 \mathrm{~s}$ \\
\hline
\end{tabular}

について横断面のビッカース硬さ $H V$ を測定した。試験方 法を表 8 に示す。

\subsection{4 顕微鏡組織の観察}

As OT及び $648 \mathrm{~K} ， 673 \mathrm{~K} ， 698 \mathrm{~K}$ 低温焼なまし材について 横断面の中間部 (d/4部) の組織観察を実施した。観察は3\% 硝酸アルコール腐食後, 光学顕微鏡にて観察した。

\subsection{5 脱炭層深さの測定}

As OT について，JSMA No.10により測定した。

\subsection{6 旧オーステナイト結晶粒度の測定}

As OT 材を $823 \mathrm{~K} \times 10 \mathrm{~h}$ 焼なまし後，JIS G 0551 Gh によ り測定した。

\subsection{7 残留オーステナイトの測定}

As OT 及び $598 \mathrm{~K} ， 698 \mathrm{~K}$ 低温焼なまし材について X 線回 折法により残留オーステナイト量を測定した。線の表面側 から測定を行い, 測定位置は表面から深さ $200 \mu \mathrm{m}$ まで化学 的に溶去しながら $50 \mu \mathrm{m}$ 深さ毎に測定した。なお As OT 材 については表面から深さ $400 \mu \mathrm{m}$ まで及び縦断面中心の測定 も行った。

表 9 に測定条件を示す。

\subsection{8 非金属介在物の測定}

As OTについて，JSMA No.13により測定，介在物評点を 求めた。

\subsection{9 表面粗さの測定}

As OTについて酸洗脱スケール後, 円周方向 8 か所の表 面粗さを測定した。測定には小坂研究所製表面粗さ測定器 (SE-4A)を用いた。

\subsubsection{0 表面きずの観察}

As OTについて，酸洗後目視及び光学顕微鏡にて観察した。

\section{2 加工性試験法}

加工性の評価のためノッチ曲げ試験による切欠き感受性 の比較と実物弁ばねコイリングでの割れ，折損の有無の確 認を行った。また，コイリング精度の比較のため自由長と コイル外径のばらつきを測定した。

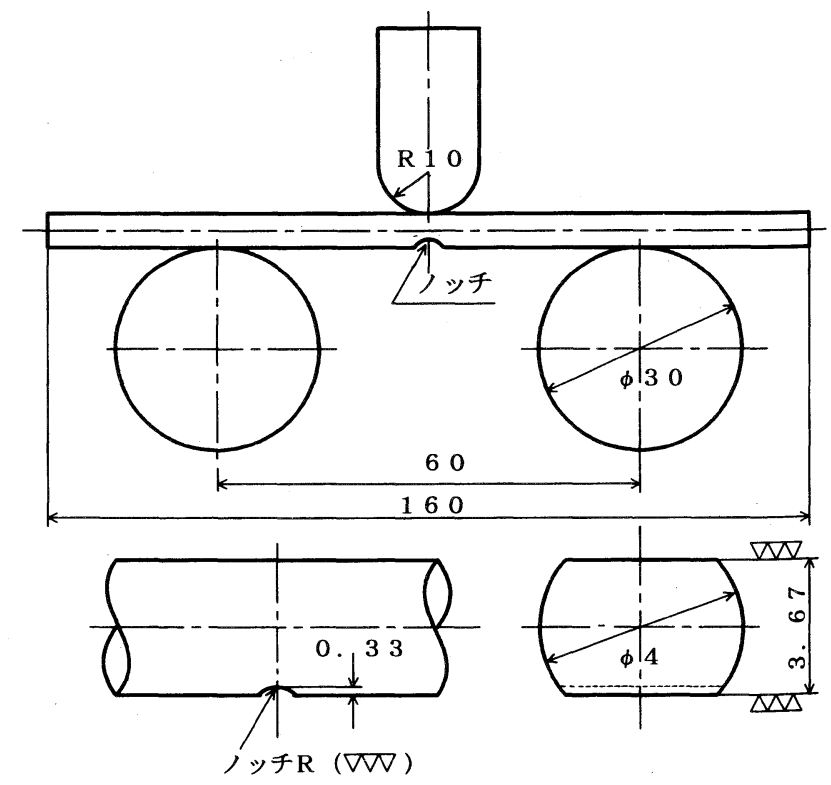

図 2 ノッチ曲げ試験片及び方法 


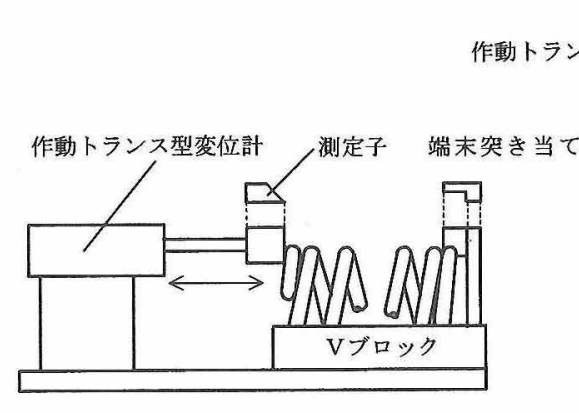

自由長测定

図 3 自由長と外径の測定方法

表 10 残留応力測定条件

\begin{tabular}{l|l}
\hline $\mathrm{X}$ 線管球 & $\mathrm{Cr}$ \\
\hline 管電流 & $40 \mathrm{kv}$ \\
\hline 管電压 & $30 \mathrm{~mA}$ \\
\hline 照射時間 & $300 \mathrm{~s}$ \\
\hline 応力定数 & $-317.9 \mathrm{MPa}$ \\
\hline 応力計算法 & $\sin ^{2} \phi$ 法 \\
\hline
\end{tabular}

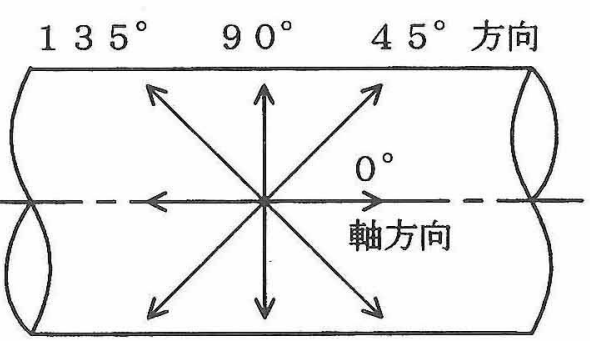

図 4 残留応力測定方向

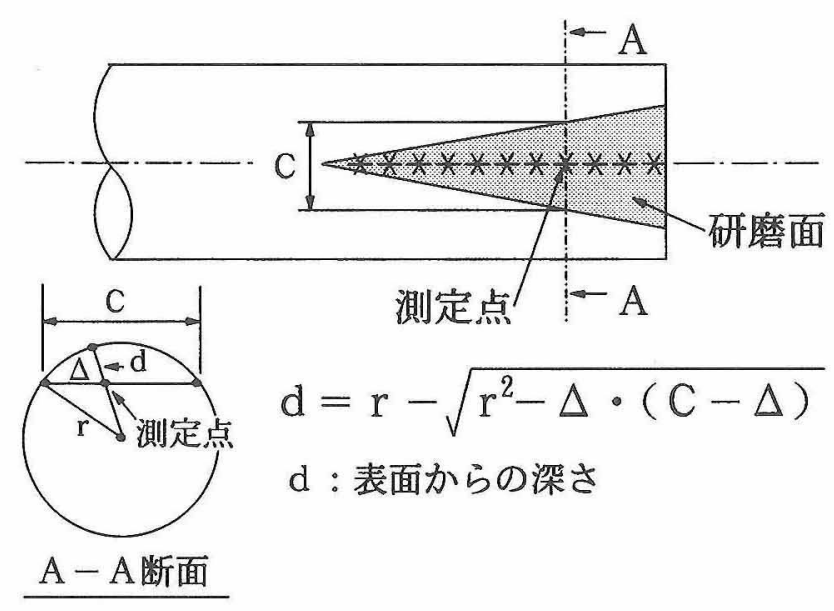

図 5 表層部硬さ分布測定方法 (コード法, 線の場合 $)^{5)}$

\subsection{1 ノッチ曲(゙試験法 ${ }^{4)}$}

実物コイリングで割れ限界を求める試験を行うとコイリ ングッールをきず付ける恐れがあり，それに代わる簡便法 としてノッチ曲げ試験を取り上げた。試験片はAs OT材を 用い,ノッチ半径は $2 \sim 14 \mathrm{~mm}$ の範囲を $2 \mathrm{~mm}$ ピッチで変 化させた。ノッチ加工方法はまず上下面を軸線に平行な方 向の研削 $(\nabla \nabla \nabla$ 仕上げ)により成形し，次いで軸線に直角
方向の研削 ( $\nabla \nabla \nabla$ 相当仕上げ)によりノッチ加工を行った。 ノッチ曲げ試験は 図 2 に示す 3 点曲げにより，ポンチを押 込んでいった場合の試験片の折損, 未折損の確認を行い, 最 大荷重及び折損材については折損までの押込从量を測定した。

なお，図 2 に示寸試験片形状は過去の懸架ばねワーキン ググループでの実績)に基づいてほぼ相対的な寸法とした もので, 曲げ試験時の試験片の安定性と適度に折損するノ ッチ深さを経験的に選定したものであるが, 理論的根拠に 基づいたものではない。また，ポンチ R10 は弁ばね加工に 近い曲げを与える条件として設定したもので, 支点間の距 離はほほJISの 3 点曲げ試験方法に準拠したものである。

\subsection{2 コイリング (加工) 性試験法}

コイリング (加工) 性試験は 2 本ピンコイリングにより, 割れ，きずなどの有無の確認を行い，また，形状の精度を 確認するために，コイリング直後の切断コイル(低温焼なま し及び座研磨をしていないもの)を各鋼種每に100本づつ抽 出し, 自由長とコイル外径を測定して平均值と標準偏差を 求めた。その測定方法を図 3 に示すが,ここでいう自由長 とはコイル端面を測定治具に突当て, 同一の巻数の位置で のばね高さを測定したものであり，いわゆる端面研削した ばねの自由高さとは異なる。

\section{3 加工ひずみ除去試験法}

加工ひずみ除去試験では，ばね内側のコイリングで生じる 引張残留応力に注目し，低温焼なまし条件の影響を調べた。 低温焼なまし温度は $573 \mathrm{~K} ７ 23 \mathrm{~K}$ の間で $100 \mathrm{~K}$ 扔きにとり， 時間は $25 \mathrm{~min}$ 一定とした。残留応力測定は理学電機製 PSPC 微小部X線応力測定装置を用いて, 表 10 に示す測定 条件によりばね内径側の表面について 図 4 に示す線軸に 対して半時計回りに $0^{\circ}$ 方向, $45^{\circ}$ 方向, $90^{\circ}$ 方向, $135^{\circ}$ 方向 で測定した。

\section{4. 疲労試験用試料の表層部物性測定法}

前出の) 図 1 の製造工程（低温焼なまし，ショットピーニ ングなど）を経た，疲労試験及びばねの場合はさらにへた り試験に用いた $1 \sim 3$ 次材の試料（線及びばね）の表層部の 硬さ，残留応力，表面粗さを測定した。

\subsection{1 硬さ分布測定法}

表層部を斜めに拡大するコード法卓を用いて, 試料の表 層部硬さ分布を測定した。ばねの場合はコイル内側の素線 表層部を測定した。参考のため，線の場合について測定方 法を図 5 に示す。

\subsection{2 残留応力分布測定法}

$\mathrm{X}$ 線応力測定装置を用いて試料の表層部残留応力を測定 した。表面から深さ方向への測定は, 温硝酸を用い化学的 に除去しながらその都度測定を行った。測定方向は, 線の 場合は線軸方向に，ばねの場合はばね内側を線軸に対し反 時計回りに $45^{\circ}$ 方向で測定した。測定条件は前出の 表 10 と 同じである。

\subsection{3 表面粗さ測定法}

試料の表面粗さは小坂研究所製表面粗さ測定機 (SE-4A) を用いて線軸方向に測定した。円周方向は曲面のため, 測 


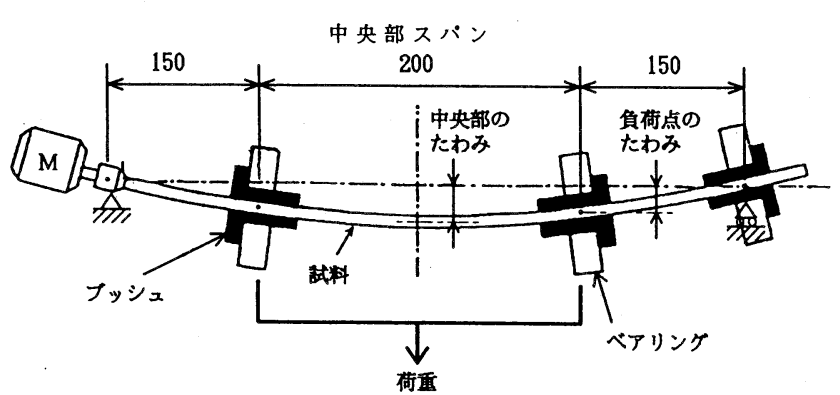

図 6 中村式回転曲げ疲労試験機の概略図

表 11 線の疲労試験及びSEM観察の分担

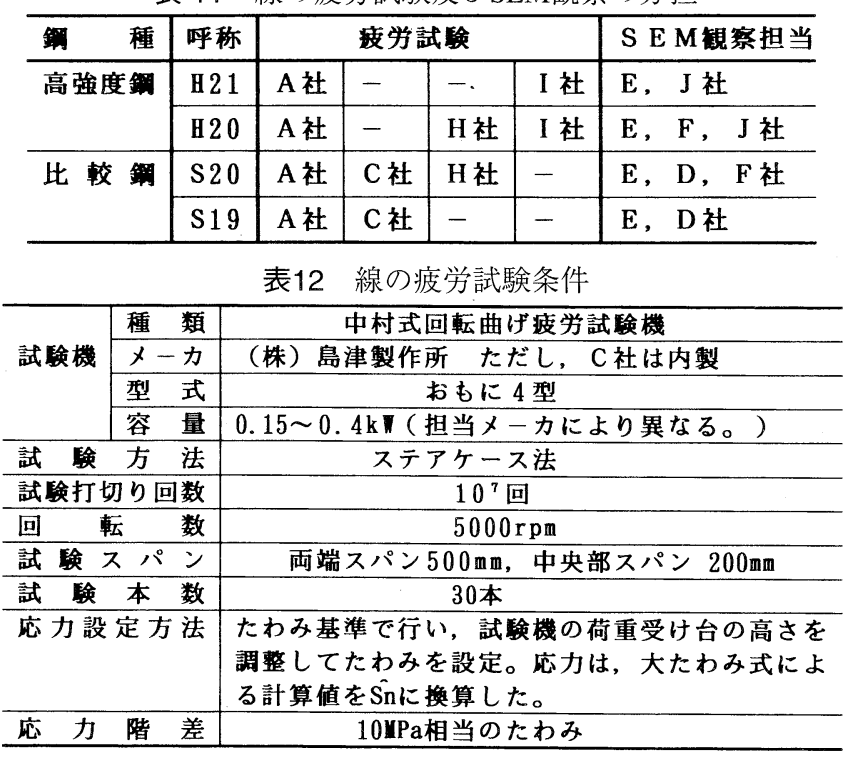

表 13 ばねの疲労試験及びSEM観察の分担 $\left(\tau_{m}=600 \mathrm{MPa}\right)$

\begin{tabular}{|c|c|c|c|c|}
\hline 笙種 & 強度レベル & 処 理 & 披労試匰担当 & S E M 観察担当 \\
\hline \multirow{6}{*}{ 高強度䑳 } & \multirow{3}{*}{$2100 \mathbf{P a}$} & 1 次材 & \multirow{3}{*}{$G, M, N$ 社 } & \multirow{3}{*}{$C, F$ 社 } \\
\hline & & 2 次材 & & \\
\hline & & 3 次材 & & \\
\hline & \multirow{3}{*}{$2000 \mathrm{~Pa}$} & 1 次材 & \multirow{3}{*}{$G, K, M, N$ 社 } & \multirow{3}{*}{$C, E, F$ 社 } \\
\hline & & 2 次材 & & \\
\hline & & 3 次材 & & \\
\hline \multirow{6}{*}{ 比较鎆 } & \multirow{3}{*}{$2000 \mathrm{~Pa}$} & 1 次材 & \multirow{3}{*}{$G, K, L, M$ 社 } & \multirow{3}{*}{$D, E, F$ 社 } \\
\hline & & 2 次材 & & \\
\hline & & 3 次材 & & \\
\hline & \multirow{3}{*}{$1900 \mathrm{MPa}$} & 1 次材 & \multirow{3}{*}{$G, L, M$ 社 } & \multirow{3}{*}{$D, F$ 社 } \\
\hline & & 2 次材 & & \\
\hline & & 3 次材 & & \\
\hline
\end{tabular}

注）K，L，M，N社は星型疲労試験機で，G社は油圧サーボ型疲学試験機で試験した。 表 14 ばねの疲労試験条件

\begin{tabular}{|c|c|c|}
\hline \multirow{4}{*}{ 試䣯機 } & 星型技労試験機 & 油压サーボ型技労試験機 \\
\hline & （株）東海試験機製作所 & カヤバ工業（株） \\
\hline & TSC-16B又は $32 \mathrm{~B}$ & Mode 16102, Type 821 \\
\hline & 5.5 (16連式 ) 11 k"（32連式 ) & 荷重 $4.9 \mathrm{kN}$ (油圧塬 $15 \mathrm{kw}$ ) \\
\hline セッチンク & 常温 $\times \tau=130$ & $\mathbf{M P a} \times 1$ 回 \\
\hline 均 応 & $\tau \mathrm{m}=550,60$ & $.700 \mathrm{YPa}$ \\
\hline 力 振 輻 & 各処理とも $\tau a= \pm 550,500$ & 450YPa前後の 3 水準 \\
\hline 武 険 本 数 & $K, L, M$ 社は各応力水準 $n=8$ & $\mathrm{G}, \mathrm{M}$ 社は各応力水準 $\mathrm{n}=4$ \\
\hline 試験打切り回数 & $5 \times 10^{7}$ & \\
\hline 試 酫 速 度 & $25 \mathrm{~Hz}$ & \\
\hline ばねの测定項目 & 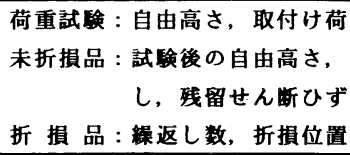 & 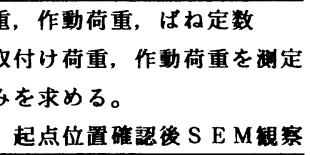 \\
\hline
\end{tabular}

定が極めて困難なために測定していない。ばねについては 最大応力が作用し疲労起点となることが予想される, ばね 内側を測定した。

\section{5 線の回転曲げ疲労試験}

線の回転曲げ疲労試験は, 中村式回転曲げ疲労試験機を 用いて行った。負荷機構の概略を図 6 に示す。たたし, 試 験に先立ち, その能力から見て数社で担当する必要がある こと, 大幅なばらつきが予想されることなどを配慮して, 参加各社の試験条件の違いを把握するため, 別の試験材を 準備して事前に比較試験を実施した。これらの結果 (図 37) や試験の負担などを考慮して, 試験は 表 11 に示すように 4 社で担当した。なお，ばらつきを考慮してブッシュは 1 社 のみで製作したものを使用し，機差の生ずることを配慮し て1社のみは全サンプルについて試験を行った。

試験条件は，表 12 に示すようにステアケース法 ${ }^{6)}$ で定 たわみ基準 ${ }^{7)}$ とした (その他の試験条件については 4.5.3 項 参照)。

\section{6 ばねの疲労試験法}

ばねの疲労試験は, 平均応力 $\tau_{m}=600 \mathrm{MPa}$ で星型疲労試 験機及び油圧サーボ型疲労試験機を用いて, 表 13 に示すよ うに 5 社で担当し, 表 14 に示す条件で $5 \times 10^{7}$ 回の試験を行 った。星型疲労試験機は一度に多数の試料の試験が行える 利点があるが，力ム駆動のためばねがへたりを生じた場合， 荷重低下を生じる欠点がある。油圧サーボ型疲労試験機で は試料数は限定されるが, へたりに応じた追尾が行われる ので平均荷重や荷重振幅に変化が生じない利点がある。今 回, 油圧サーボ型疲労試験機により本供試コイルばねの時 間強度のめどをつける目的で, 星型疲労試験機に先行して 振幅一定の試験を行った。星型疲労試験では各社保有のカ ムを用いたため, 振幅が限定される欠点があるが, 両試験 機とも入力は正弦波とし, 振幅一定で試験したため本質的 な差はない。また, 本供試コイルばねの 1 次固有振動数は $781 \mathrm{~Hz}$ であり, 両試験機ともに試験速度が $25 \mathrm{~Hz}$ と小さい ためサージングのおそれはなかった。なお, 疲労試験に先 立ち荷重試験を行い, 所定のばね高さ (取付け荷重, 作動荷 重に相当するばね高さ $41 \mathrm{~mm}, 31 \mathrm{~mm}$ ) での荷重を求め, 疲

表 15 ばねの追加疲労試験機の分担 $\left(\tau_{m}=550,700 \mathrm{MPa}\right)$

\begin{tabular}{|c|c|c|c|c|}
\hline \multirow[t]{2}{*}{ 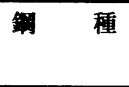 } & \multirow[t]{2}{*}{ 強度レベル } & \multirow[t]{2}{*}{ 処 理 } & \multicolumn{2}{|c|}{ 疲労試験担当及び S E M 铸察担当 } \\
\hline & & & $\tau=550 \mathrm{MPa}$ & $\tau \mathrm{m}=700 \mathrm{MPa}$ \\
\hline \multirow[t]{2}{*}{ 高強度釗 } & $2100 \mathrm{PPa}$ & 1 次材 & L 社 & N社 \\
\hline & $2000 \mathrm{YPa}$ & 1 次材 & L 社 & $\mathrm{N}$ 社 \\
\hline \multirow[t]{2}{*}{ 比較鐡 } & $2000 \mathrm{YPa}$ & 1 次材 & $\mathrm{L}$ 社 & $\mathrm{N}$ 社 \\
\hline & $1900 \mathrm{YPa}$ & 1 次材 & $\mathrm{L}$ 社 & $\mathrm{N}$ 社 \\
\hline
\end{tabular}

注）追加試験は星型疲労試験機で行った。

表 16 締付け試験条件

\begin{tabular}{l|l}
\hline 締付け応力 & 設定目標で $500,700,800,900 \mathrm{MPa}$ の 4 水準 \\
\hline 締付け温度 & 常温 $(293 \mathrm{~K}), 373 \mathrm{~K}, 473 \mathrm{~K}$ の 3 水準 \\
\hline 締付け時間 & $3,10,30,100,300,1000 \mathrm{~h}$ の 6 水準 \\
\hline 試 臨 本 数 & 各 2 個 \\
\hline
\end{tabular}


労試験後, 未折損品については再度荷重試験を行い, 試験 前後の荷重の変化量より残留せん断ひずみを求めた。折損 品については折損までの繰返し数, 折損位置, 起点位置な どを確認のうえ, 走査電子顕微鏡 $(\mathrm{SEM})$ 観察を表 13 に示 す 4 社で行った。また, 同様にして平均応力 $\tau_{m}=550$, $700 \mathrm{MPa}$ の疲労試験を追加した。担当は, 表 15 に示すが, 試験は星型疲労試験機を用いた。

\section{7 ばねの締付け試験法}

耐へたり性を評価するために，表 16 に示す条件でばねの 締付け試験を行った。試験には図 7 に示すようにステンレ ス製の治具を用いた。試験方法は耐熱ばね材料委員会の共 同研究報告 ${ }^{8)}$ を参考に間欠法を採用した。すなわち，コイ ルばねを試験治具に取付け, 所定のばね高さまで締付けた 状態で, 所定の試験温度, 時間に保持し, その後室温まで 冷却してばねの締付けを解除した。この時, 弾性余効によ る回復現象があり, 締付け解除直後の荷重測定は不可能な ため一昼夜放置後ばね試験機により所定の高さにおける荷 重を測定し，荷重損失を算出した。以下，再びこのばねを 試験治具にセットし, 所定の時間経過後に取出し, 前と同 様にして荷重損失を求めることを繰返した。へたりは，次 式に示す残留せん断ひずみによって評価した。したがって, 締付け応力は応力修正係数を含んでいない。
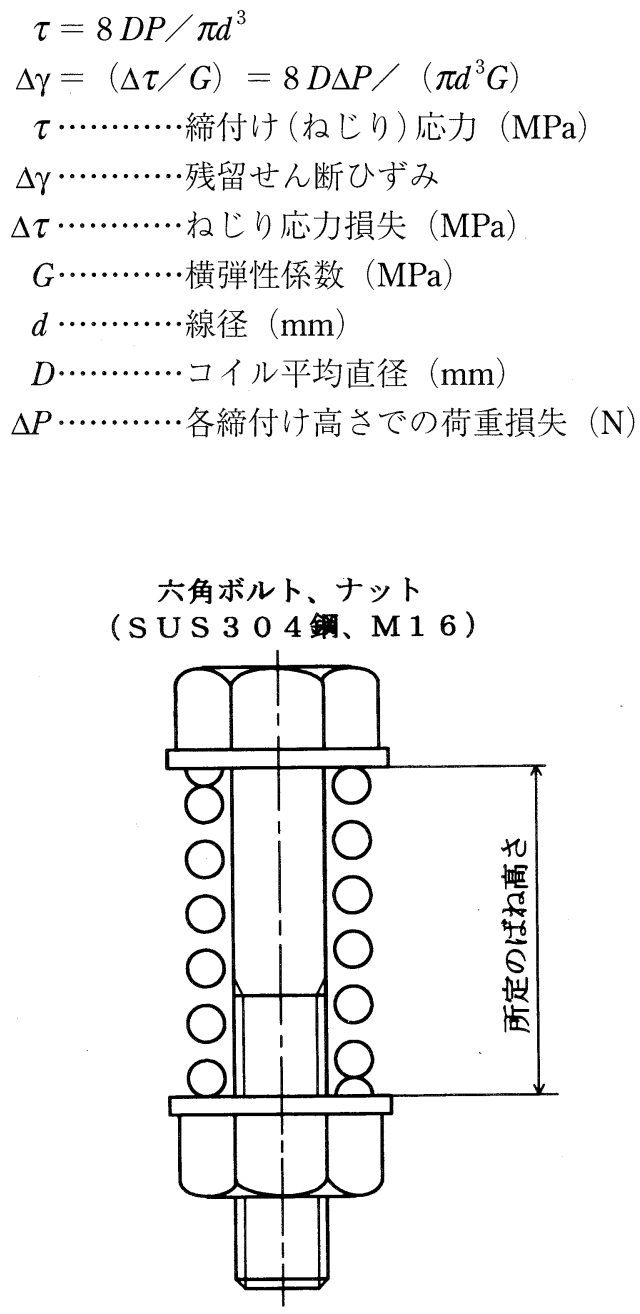

図 7 締付け試験治具

\section{1 材料試験結果}

\section{4. 試験結果及び考察}

\subsection{1 引張試験結果}

引張特性の低温焼なましによる変化を 図 8 に示す。引張 り強さ $\sigma_{B}$ は，いずれの供試材 (H21, H20, S20 及び S19) も 673K までは概ねそれぞれの As OTとほぼ同等か若干高 めの数值で安定しているが，それをこえると $\sigma_{B}$ が低下した。 低下の度合いは，それぞれ同一鋼種の中でもオイテンパー 処理時の焼もどし温度の低い H21, S20 の方が若干大きい 傾向が見られた。

耐力は $\sigma_{0.2}, \sigma_{0.05}$ ともに $\sigma_{B}$ とほぼ同様の傾向が見られる が，それらの值がAs OTより低下する低温焼なまし温度は $698 \mathrm{~K}$ と少し高温側になっている。応力比 $\sigma_{0.02} / \sigma_{B}$ の值は, 低温焼なましにより As OTよりやや高くなる傾向にあった。 その值は高強度鋼 $(\mathrm{H} 21, \mathrm{H} 20)$ の方が比較鋼 $(\mathrm{S} 20, \mathrm{~S} 19)$ よ り若干高い傾向にある。これは後述のようにV 添加の高強 度鋼の方が旧オーステナイト結晶粒度が細かかったことに 起因すると考えられる。縦弾性係数 $E$ は低温焼なまし材で 190GPa 程度で，通常言われている205.8GPaより低い值で あった。伸び $\delta$ は $\sigma_{0.2} / \sigma_{B}$ の高い高強度鋼の方が若干低い傾 向が見られ，また，低温焼なましによりAs OTより低下す るが， $\sigma_{B}$ の低下に伴い回復する傾向にある。絞り $\phi$ は供試 材間においても，また低温焼なましによっても大きな差や 変化は認められなかった。

\subsection{2 ねじり試験結果}

ねじり特性の低温焼なましによる変化を図 9 に示す。ね じり特性の低温焼なましによる変化は，概ね引張特性と同 様であった。

応力比 $\tau_{0.3} / \tau_{B}$ は, 引張特性と同様高強度鋼の方が高かっ た。横弾性係数 $G$ は若干のばらつきはあるが， $72.5 \mathrm{GPa}$ $77.5 \mathrm{GPa}$ の範囲であった。破断ねじり回数 $T n$ は S19 が比 較的高かったが，他はほぼ同等であった。

$T n$ は低温焼なましにより As OTより低下するが， $\tau_{B}$ の 低下に伴い回復する傾向にある。

応力比 $\tau_{B} / \sigma_{B}$ は若干ばらつきはあるが，概ね 0.57 程度で あった。

\subsection{3 硬さ試験結果}

硬さ特性の低温焼なましによる変化を図 10 に示す。ビ ッカース硬さ $H V$ は引張試験, ねじり試験における $\sigma_{B}, \tau_{B}$ と大略同様の挙動を示している。若干のばらつきはあるが, $\sigma_{B} / H V=3.2 \sim 3.3 ， \tau_{B} / H V=1.8 \sim 1.9$ 程度であった。

\subsection{4 組織}

光学顕微鏡組織写真を図 11, 12 に示す。いずれの供試 材ともに微細な焼もどしマルテンサイトであった。また， 図 11，12 を比較すると旧オーステナイト結晶粒度の細かい 高強度鋼の方が組織がより微細であった。

\subsection{5 脱炭層深さ}

いずれの供試材も表面の脱炭組織は観察されなかった。

\subsection{6 旧オーステナイト結晶粒度}

光学顕微鏡による旧オーステナイト結晶粒写真を図 13 


\begin{tabular}{|c|c|c|c|}
\hline 鋼種 & $\begin{array}{c}\text { 強度 } V \text { (ベN } \\
(\mathrm{MPa})\end{array}$ & 呼称 & 記号 \\
\hline 高強度鋼 & 2100 & $\mathrm{H} 21$ & $\cdots$ \\
\cline { 2 - 4 } & 2000 & $\mathrm{H} 20$ & $\cdots$ \\
\hline \multirow{2}{*}{ 比較鋼 } & 2000 & $\mathrm{~S} 20$ & $\cdots$ \\
\cline { 2 - 4 } & 1900 & $\mathrm{~S} 19$ & - \\
\hline
\end{tabular}

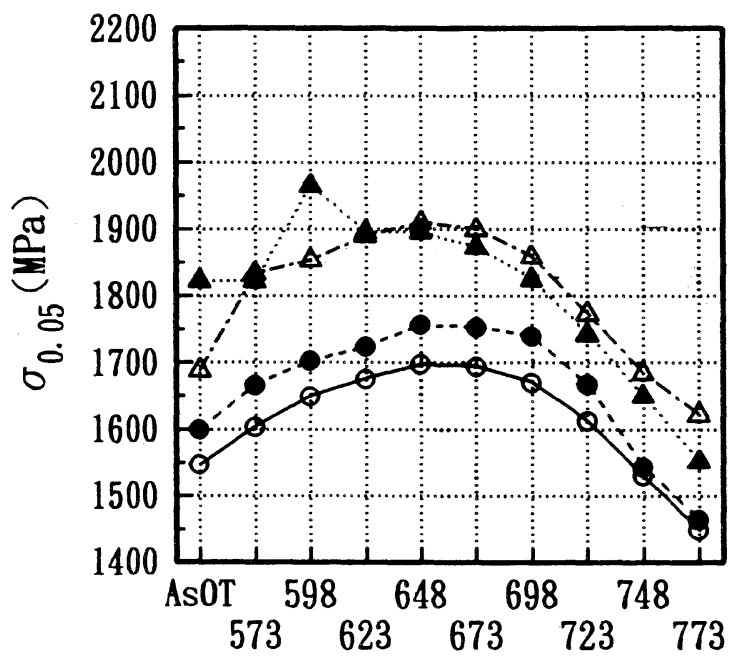

低温焼なまし温度 $(K \times 25 \mathrm{~min})$

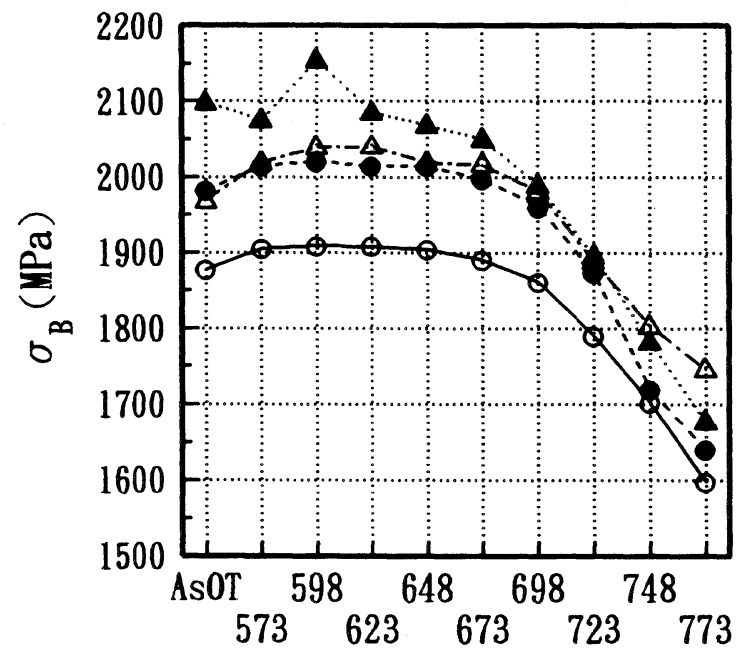

低温焼なまし温度 $(K \times 25 m$ in $)$

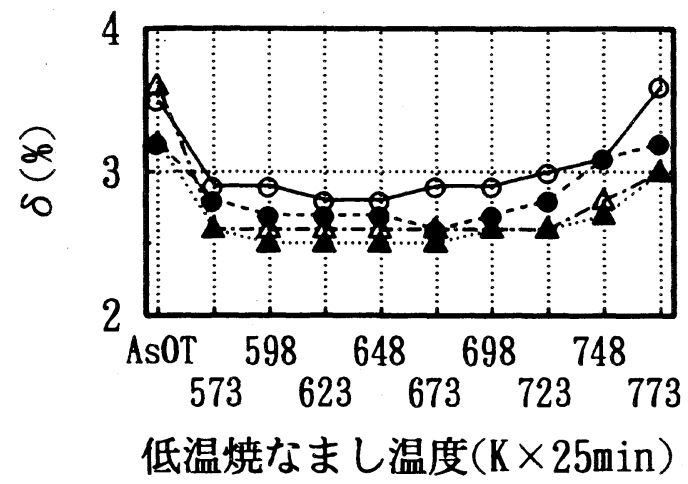

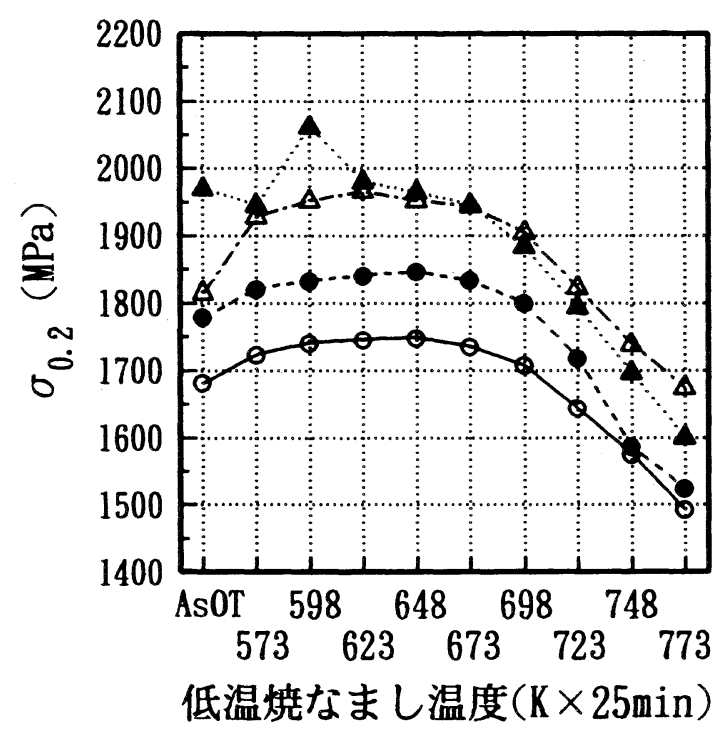
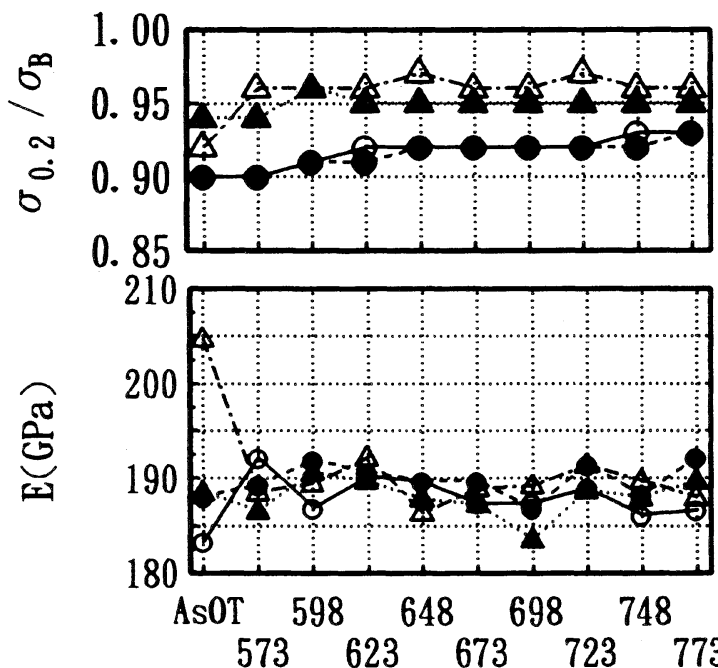

低温焼なまし温度 $(K \times 25 \mathrm{~min})$

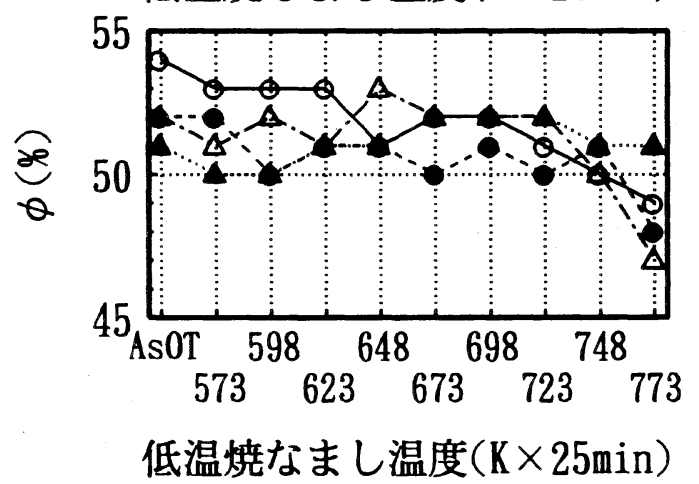

図 8 引張特性の低温焼なましによる変化 

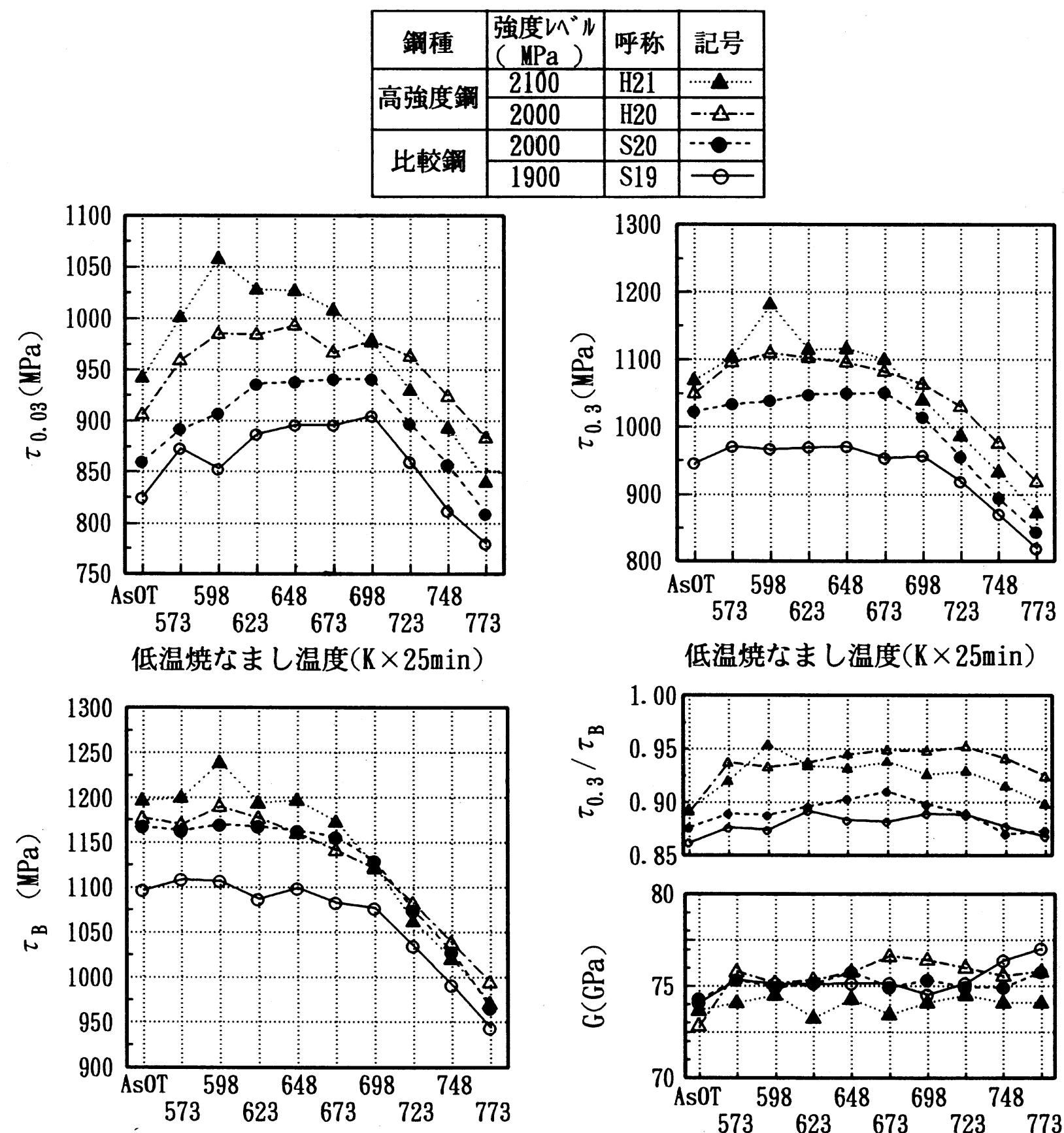

低温焼なまし温度 $(K \times 25 m i n)$
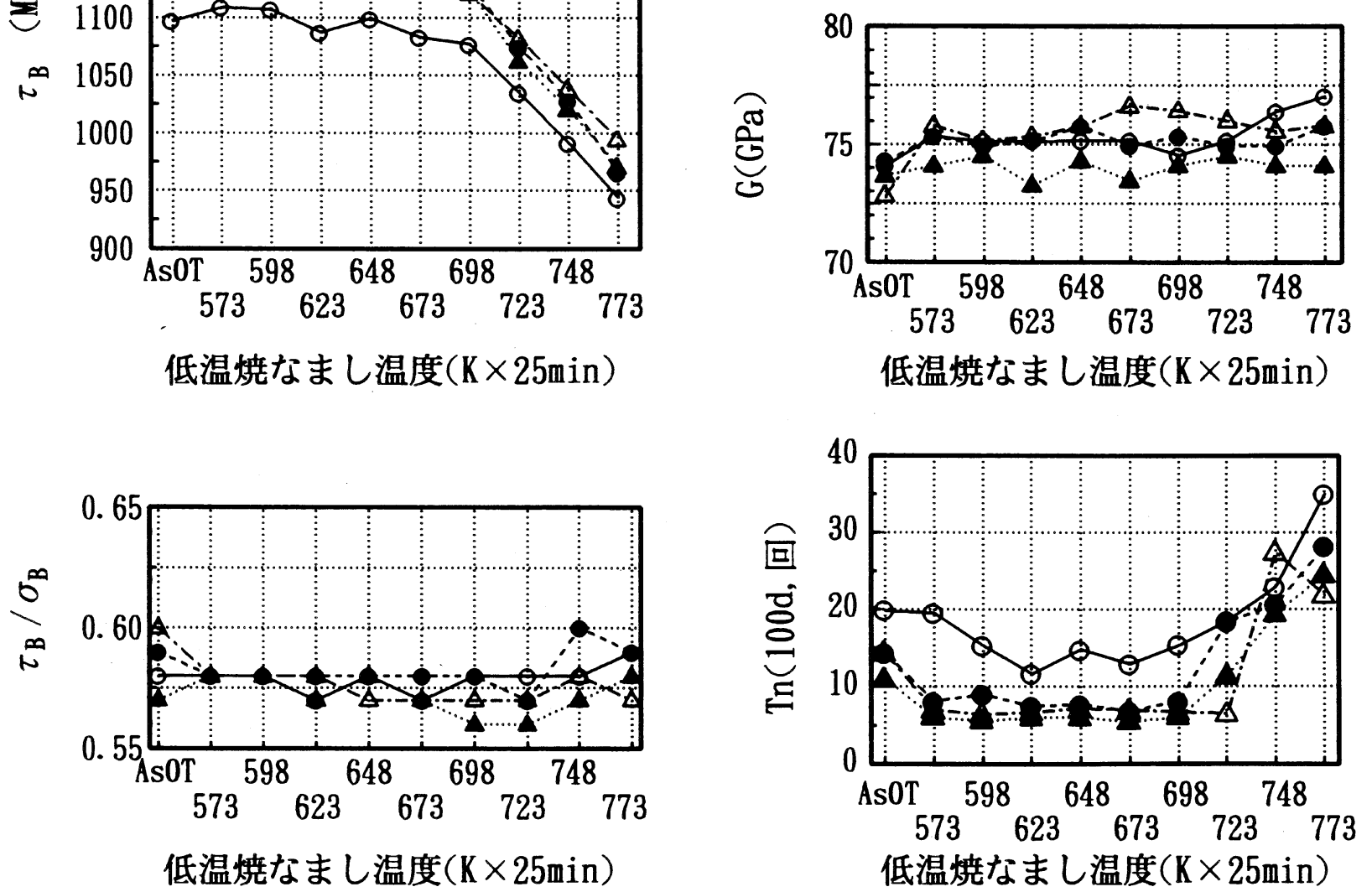

低温焼なまし温度 $(K \times 25 \mathrm{~min})$

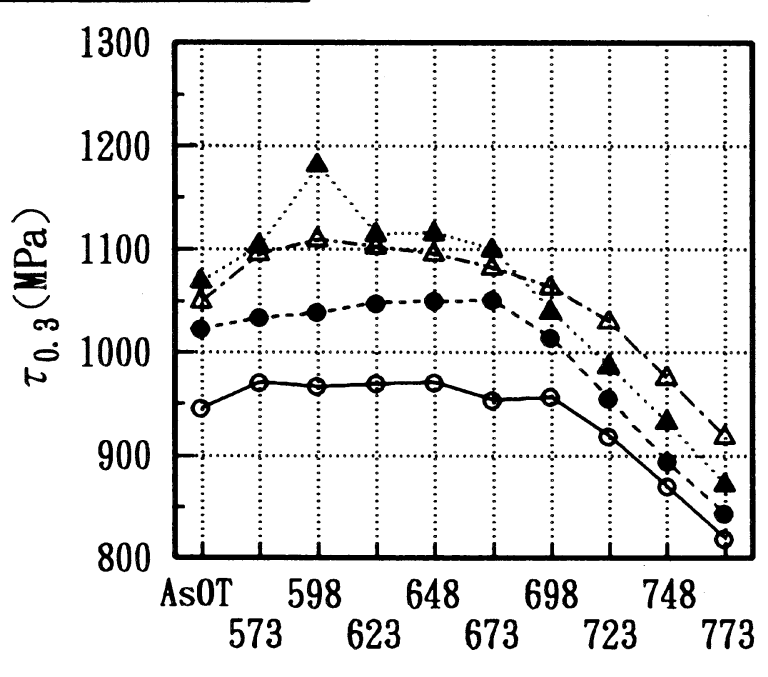

低温焼なまし温度 $(K \times 25 \mathrm{~min})$ 


\begin{tabular}{|c|c|c|c|}
\hline 鍮種 & $\begin{array}{l}\text { 強度 } V n^{\prime} N \\
(\mathrm{MPa})\end{array}$ & 呼称 & 記号 \\
\hline \multirow{2}{*}{ 高強度鋼 } & 2100 & H21 & $\mathbf{\Lambda}$ \\
\hline & 2000 & $\mathrm{H} 2 \mathrm{O}$ & $-\Delta$ \\
\hline \multirow{2}{*}{ 比較龬 } & 2000 & S20 & $\cdots$ \\
\hline & 1900 & S19 & $\sigma$ \\
\hline
\end{tabular}
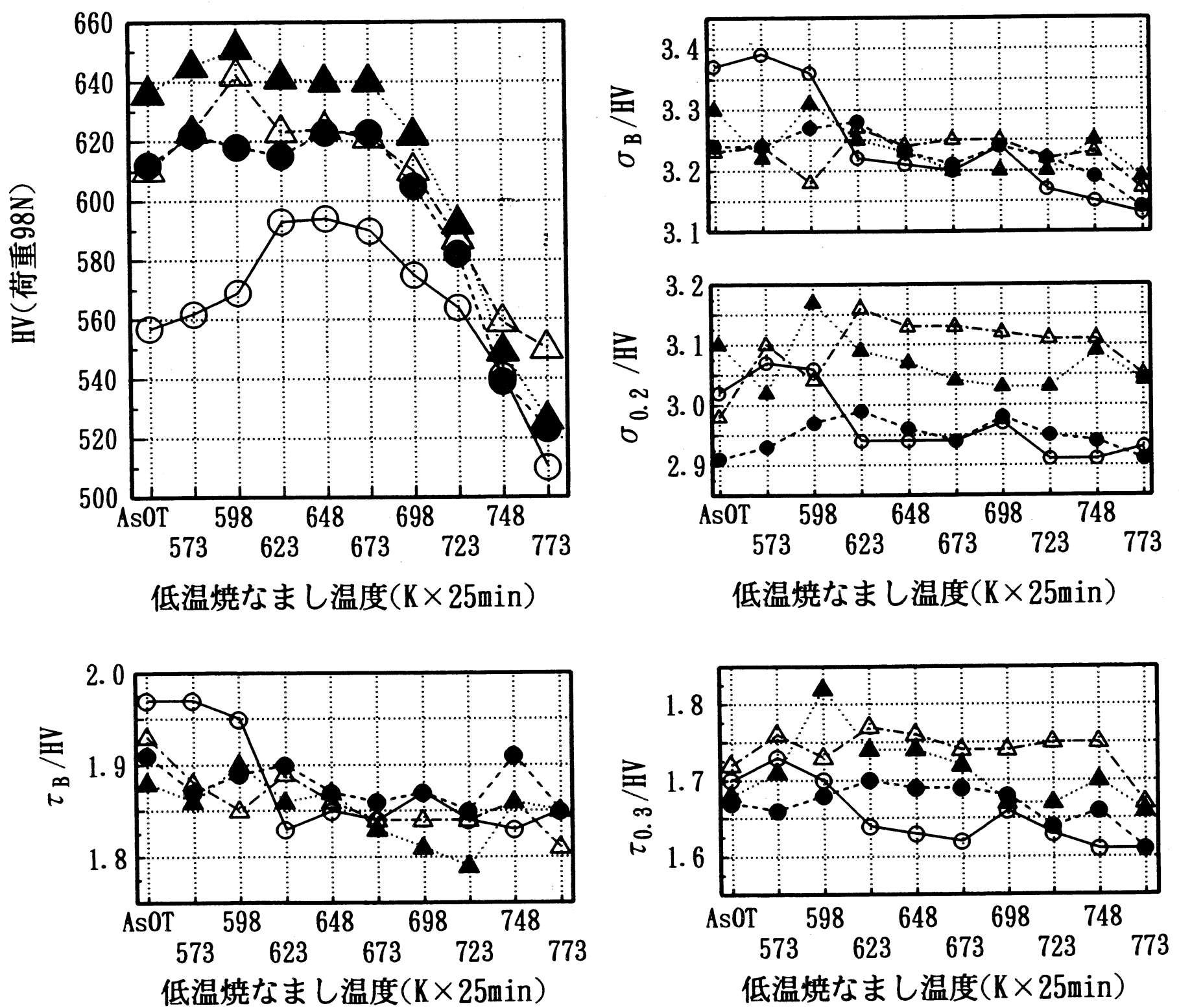

図 10 硬さ特性の低温焼なましによる変化 


\begin{tabular}{|c|c|c|}
\hline & H21（2100MPaレベル） & H20（2000MPaレベル） \\
\hline As OT & 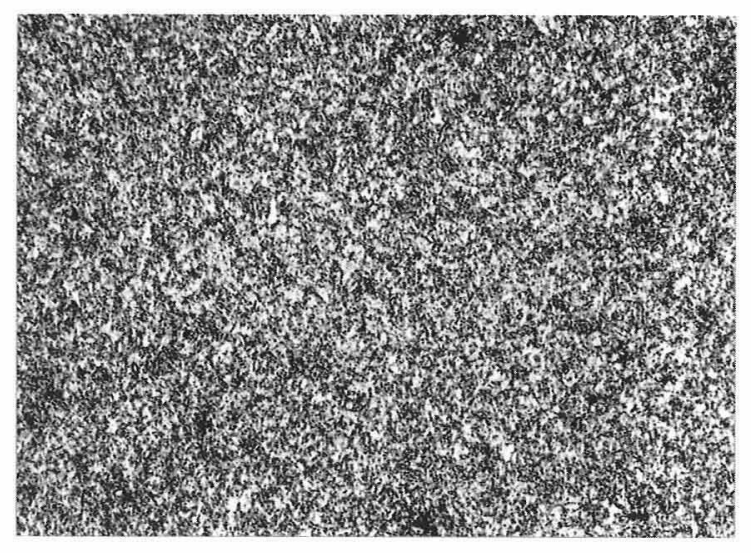 & (2) \\
\hline $648 \mathrm{~K}$ & 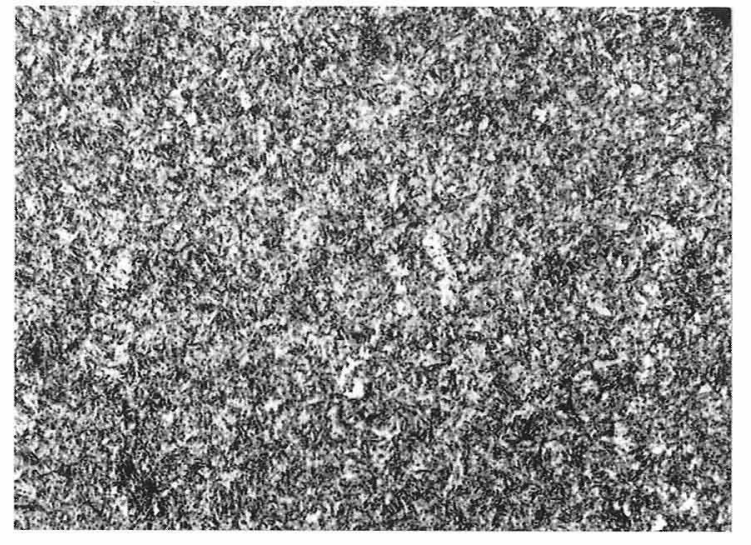 & (2) \\
\hline $673 \mathrm{~K}$ & 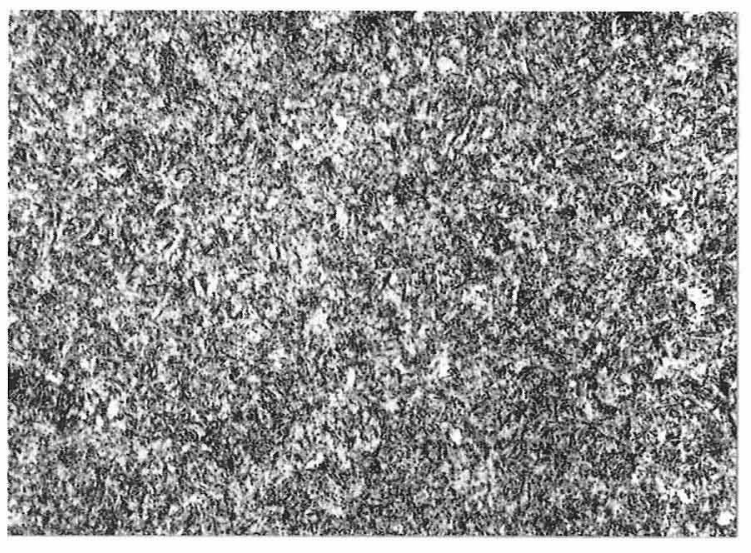 & 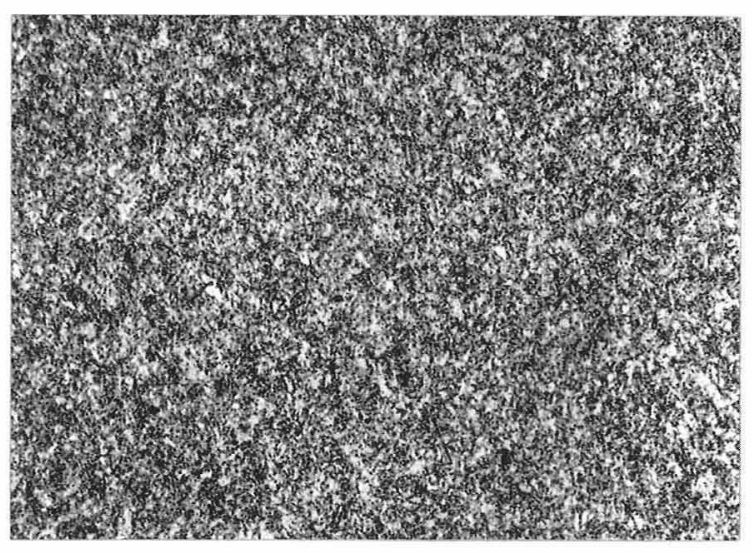 \\
\hline $673 \mathrm{~K}$ & 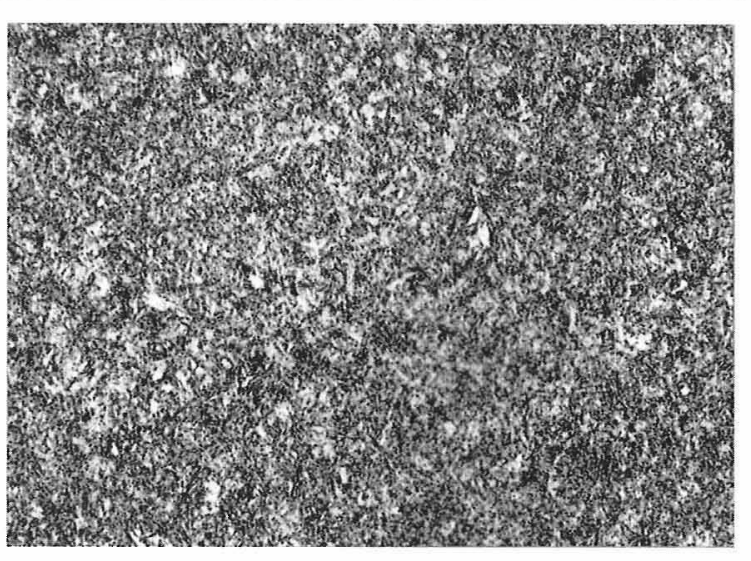 & 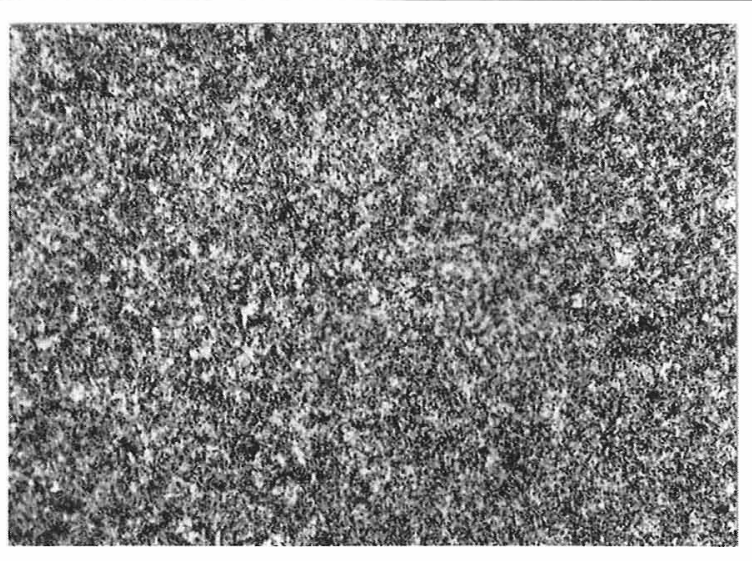 \\
\hline
\end{tabular}

図 11 高強度鋼の光学顕微鏡組織写真（横断面，中間部 $(\mathrm{d} / 4))$ $50 \mu \mathrm{m}$ 


\begin{tabular}{|c|c|c|}
\hline & S20（2000MPaレベル） & S19（1900MPaレベル） \\
\hline As OT & 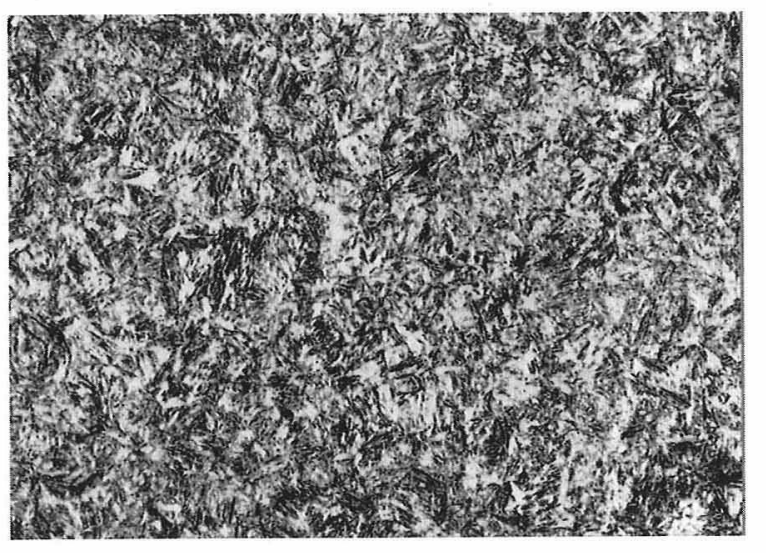 & 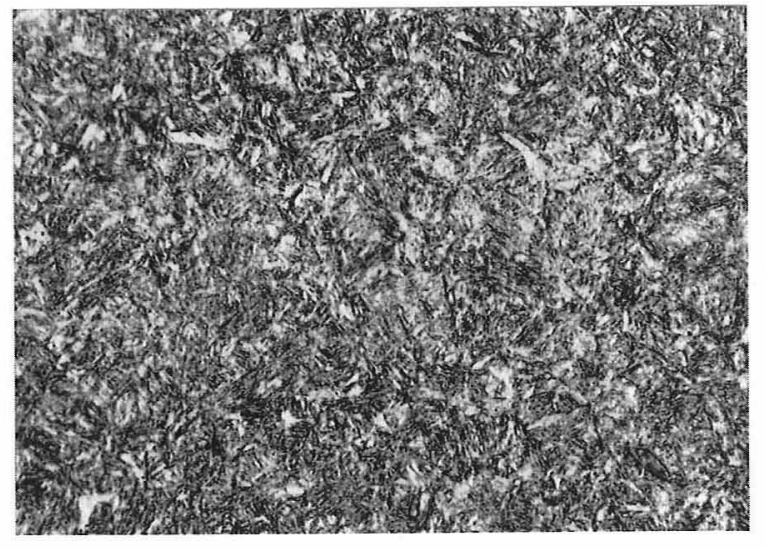 \\
\hline $648 \mathrm{~K}$ & 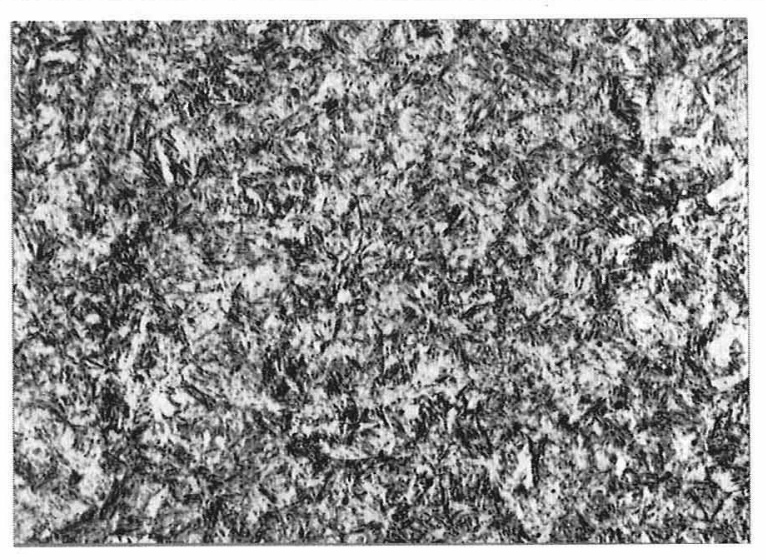 & (6) \\
\hline $673 \mathrm{~K}$ & 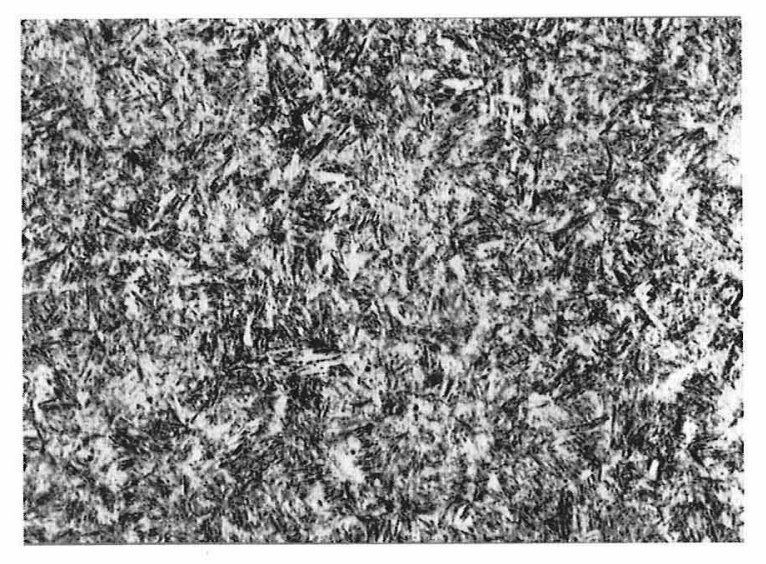 & (2) \\
\hline $673 \mathrm{~K}$ & 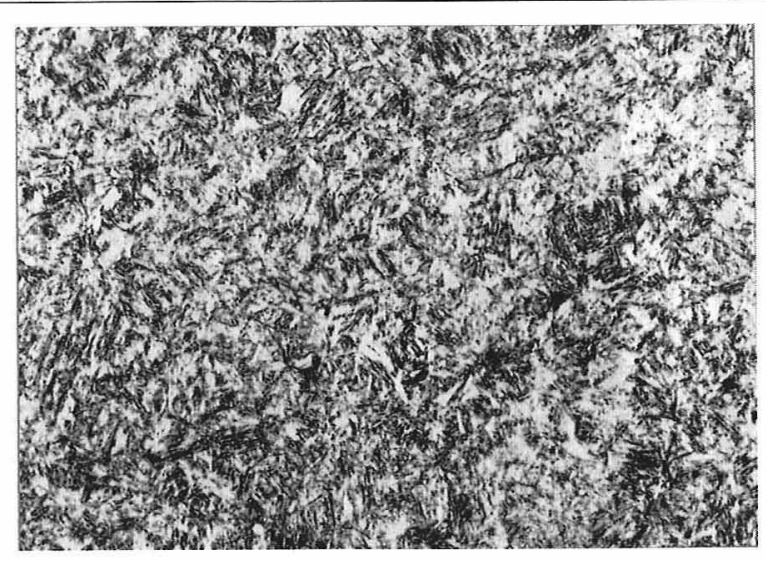 & 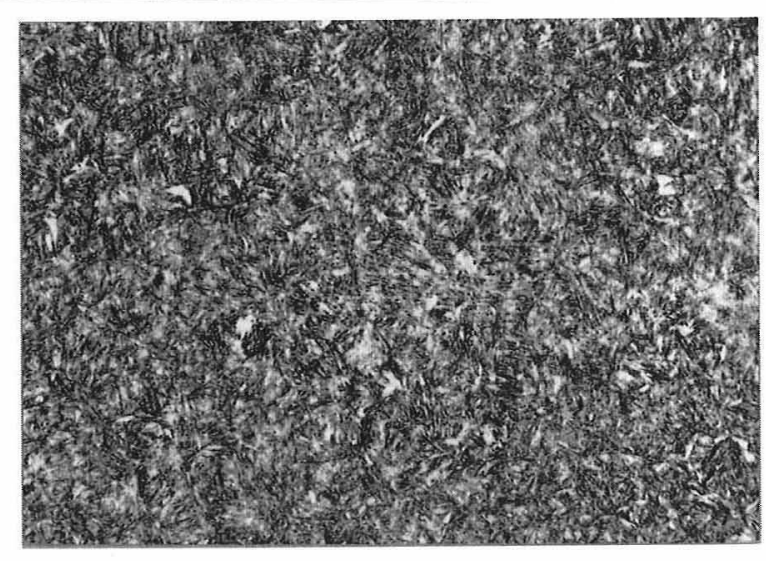 \\
\hline
\end{tabular}

図 12 比較鋼の光学題微鏡組織写真（横断面, 中間部 $(\mathrm{d} / 4)$ ) 


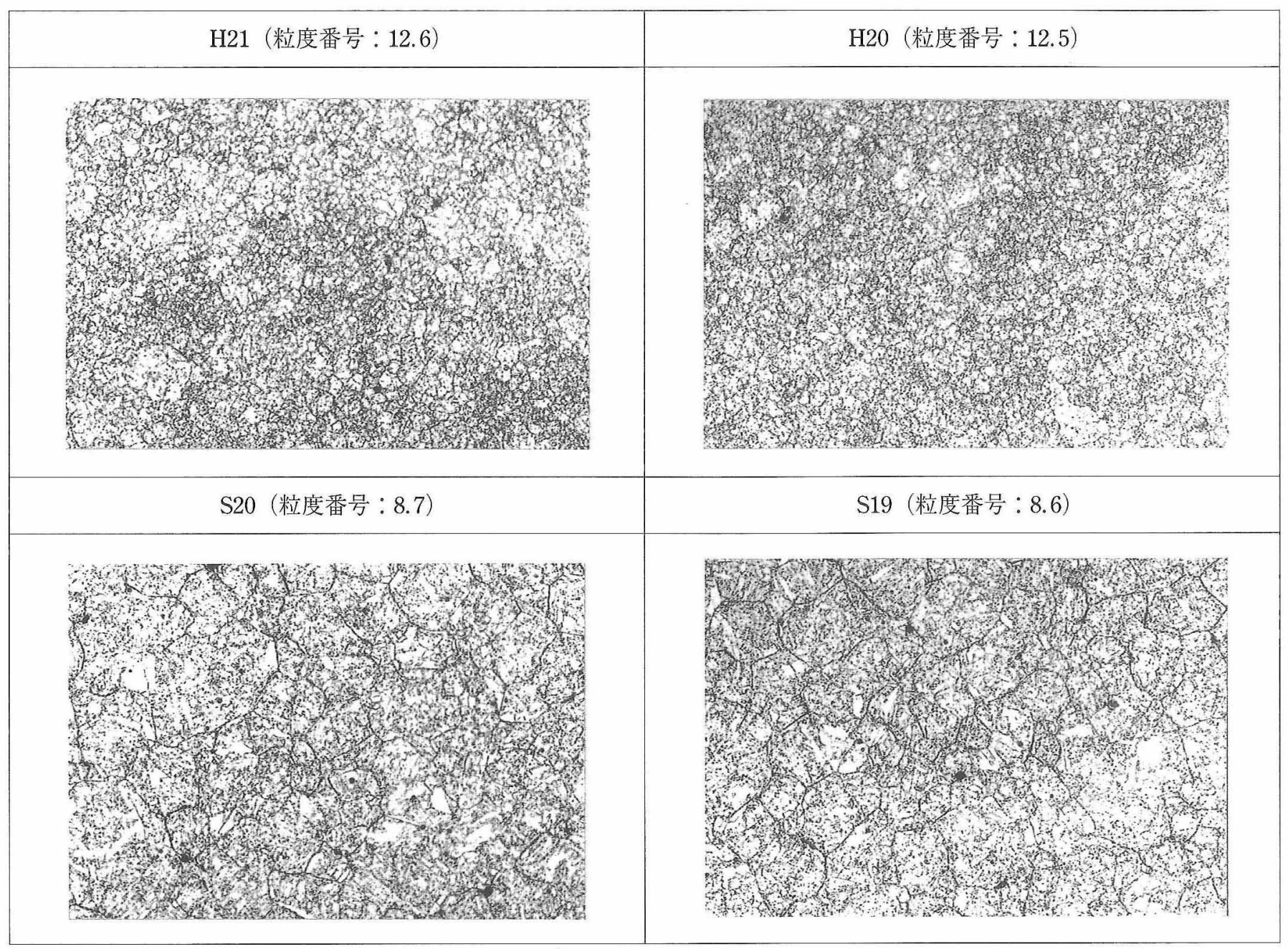

図 13 旧オーステナイト結晶粒度写真（横断面, 中間部 (d/4))

$40 \mu \mathrm{m}$

\begin{tabular}{|c|c|c|c|}
\hline 鋼種 & $\begin{array}{l}\text { 强度 } \mathrm{WA}^{\circ} \mathrm{N} \\
(\mathrm{MPa})\end{array}$ & 呼称 & 記号 \\
\hline \multirow{2}{*}{ 高強度銅 } & 2100 & 1121 & $\cdots \cdots$ \\
\hline & 2000 & $\mathrm{H} 20$ & $-\Delta .-$ \\
\hline \multirow{2}{*}{ 比較鎆 } & 2000 & $\$ 20$ & $\cdots$ \\
\hline & 1900 & $\$ 19$ & 0 \\
\hline
\end{tabular}
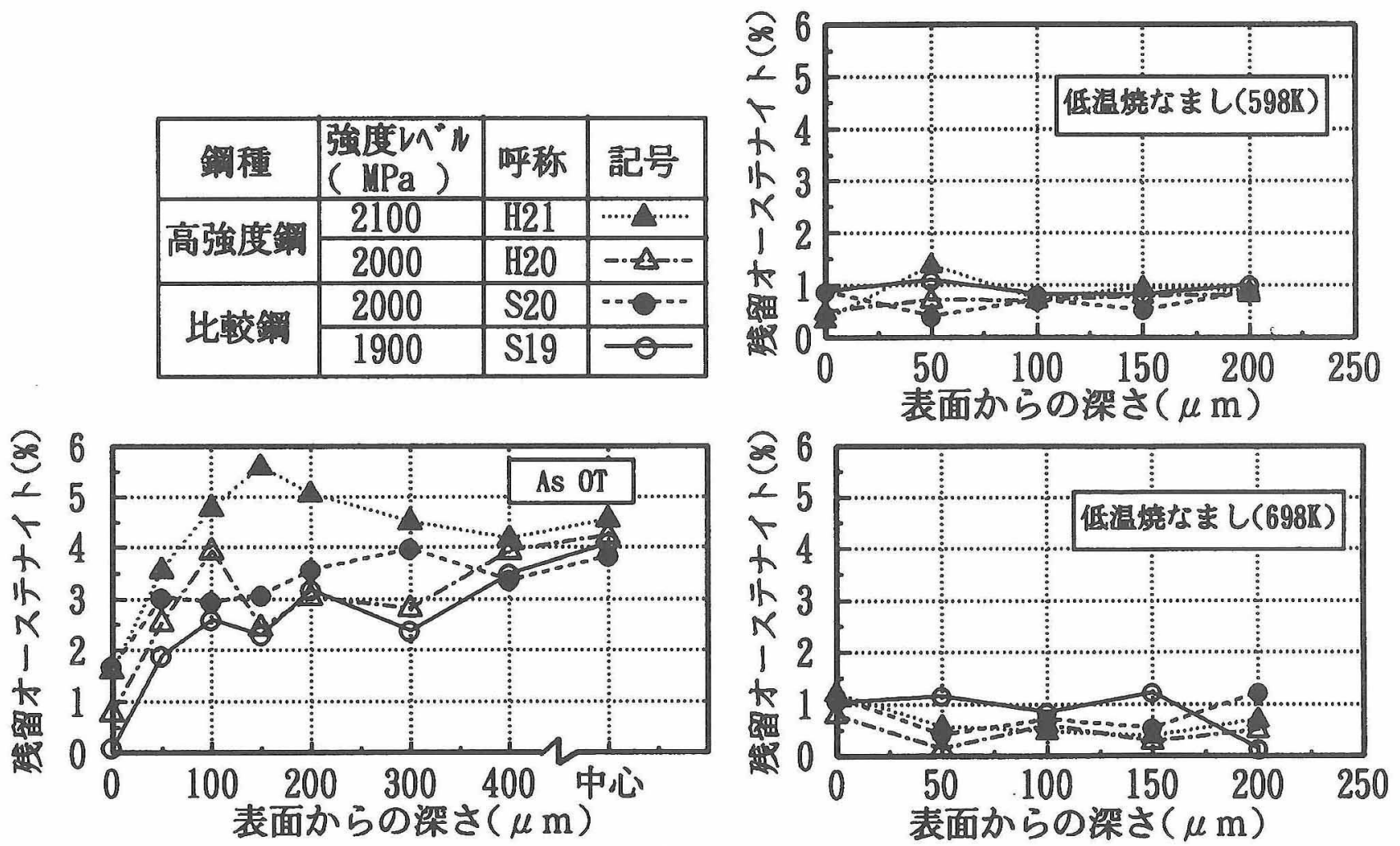

図 14 供試材の残留オーステナイト測定結果 
に示す。いずれの供試材ともに整細粒であった。JIS G 0551 Gh で12.6 (H21), 12.5 (H20), 8.7 (S20), 8.6 (S19) であり, $\mathrm{V}$ 添加の高強度鋼の方が粒度番号で 4 番程度細粒であった。

\subsection{7 残留オーステナイト}

残留オーステナイトの測定結果を図 14 に示す。As OT
材の残留オーステナイトについては，最表面部は少ないが, それより内部では 2 〜 \% 程度の残留オーステナイト量で あった。しかし，598Kあるいは 698K 低温焼なましにより 表層から $200 \mu \mathrm{m}$ 深さまでの残留オーステナイト量は全て $1 \%$ 以に減少していた。

表 17 非金属介在物（JSMA No.13）及び表面粗さ測定結果

\begin{tabular}{|c|c|c|c|c|c|c|c|c|}
\hline \multirow{2}{*}{ 種 } & \multirow{2}{*}{$\begin{array}{r}\text { 強度レペル } \\
(\mathbf{P a}) \\
\end{array}$} & \multirow[b]{2}{*}{ 呼称 } & \multirow{2}{*}{$\begin{array}{l}\text { 介在物 } \\
\text { 評点 }\end{array}$} & \multicolumn{2}{|c|}{ 介在物因数（固） } & \multicolumn{3}{|c|}{ 表面粗さ（ $\boldsymbol{\mu} \mathrm{m})$} \\
\hline & & & & $5 \sim 10 \mu \mathrm{m}$ & $10 \mu \mathrm{m}$ 超え & $\mathrm{R} \mathbf{a}$ & $R=a x$ & $\mathrm{Rz}$ \\
\hline \multirow[t]{2}{*}{ 高強度策 } & 2100 & H 21 & 1 & 1 & 0 & 0.6 & 5.3 & 3.6 \\
\hline & 2000 & H 20 & 0 & 0 & 0 & 0.9 & 6.3 & 4.6 \\
\hline \multirow[t]{2}{*}{ 比敦 } & 2000 & $\mathrm{~s} 20$ & 2 & 2 & 0 & 1.6 & 8.7 & 6.1 \\
\hline & 1900 & $\$ 19$ & 1 & 1 & 0 & 1.0 & 7.1 & 4.2 \\
\hline
\end{tabular}

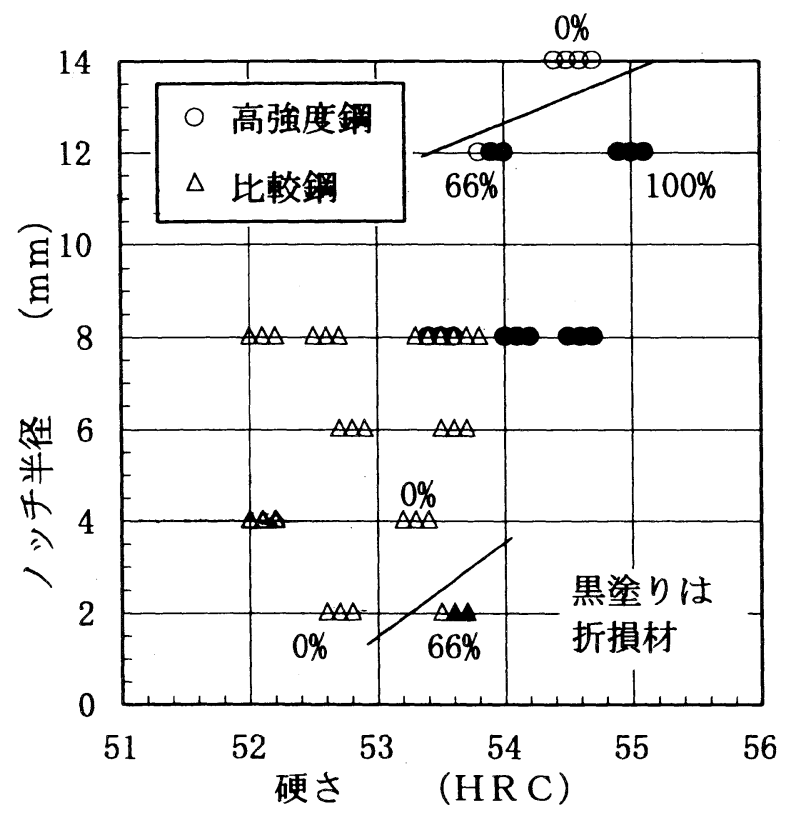

図 15 折損/未折損ノッチ半径と硬さの関係 (図中の線は折損率50\%ノッチ半径を示す。)

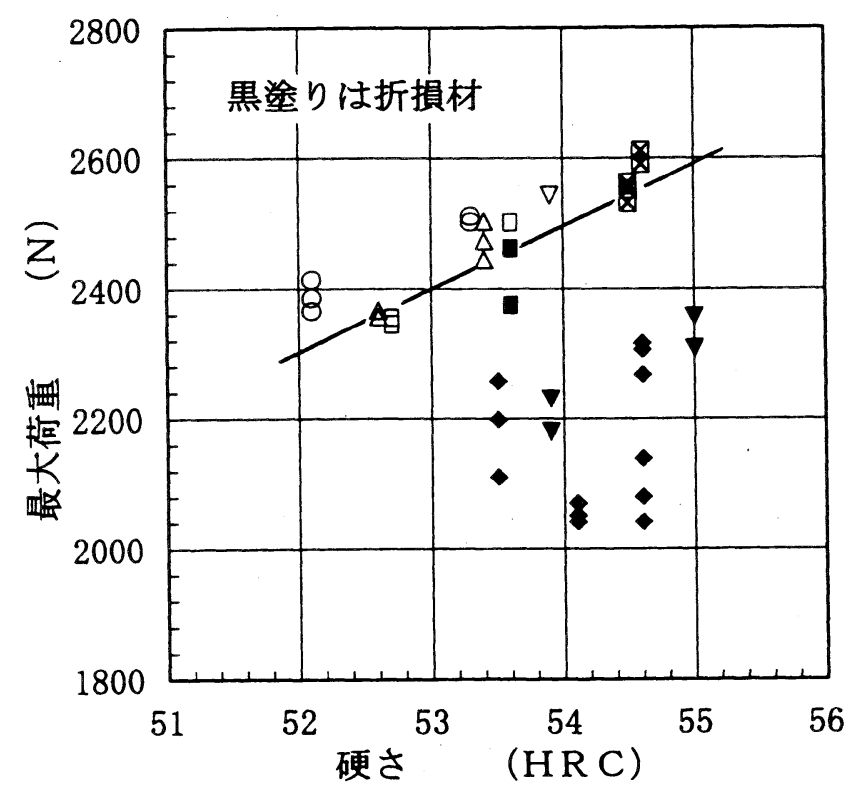

図 16 最大荷重と硬さの関係

\subsection{8 非金属介在物}

JSMA No.13 により測定した介在物評点を表 17 に示す。 いずれの供試材も $10 \mu \mathrm{m}$ を越える介在物は見られなかった。

\subsection{9 表面粗さ9}

表面粗さの測定結果を 表 17 に示す。やや比較鋼の方が 粗い傾向があるがその差は小さい。

\section{1 .10 表面きず}

一部の供試材に線状きずが見られたが，媣さ $10 \mu \mathrm{m} に も$ 満たない軽微なものであった。

注) 図16，17 亿用いた記号

\begin{tabular}{|c|c|}
\hline $\boldsymbol{\Delta}$ & 高強度鋼ノッチ半径 $14 \mathrm{~mm}$ \\
\hline$\nabla$ & 高強度鎆ノッチ半径 $12 \mathrm{~mm}$ \\
\hline$\diamond$ & 高強度銅ノッチ半径 $8 \mathrm{~mm}$ \\
\hline$\Delta$ & 比較鋼ノッチ半径 $8 \mathrm{~mm}$ \\
\hline O & 比較鎆ノッチ半径 $4 \mathrm{~mm}$ \\
\hline Q & 比較䤡ノソチ半径 $2 \mathrm{~mm}$ \\
\hline
\end{tabular}

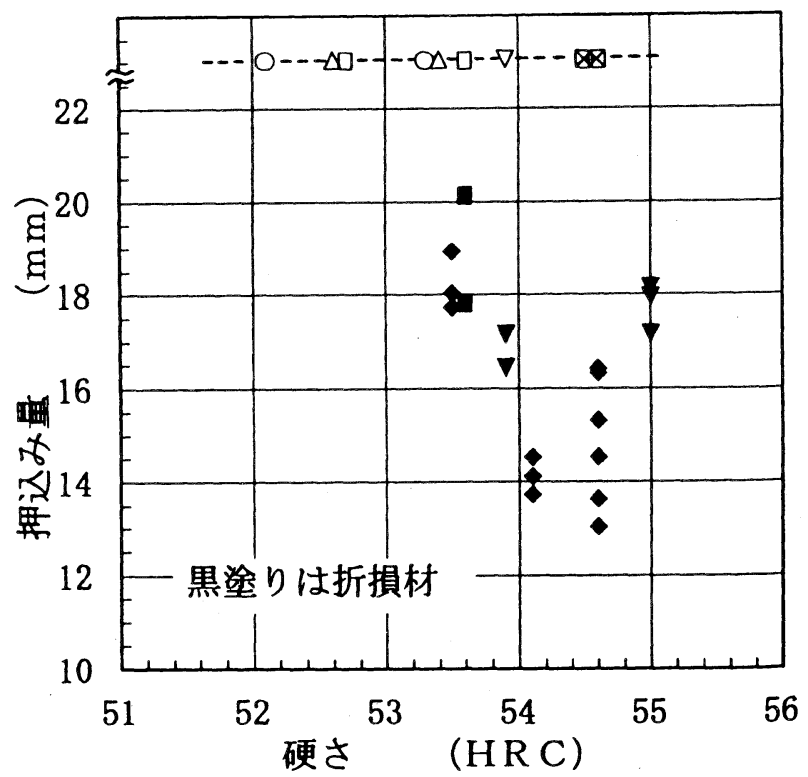

図 17 折損までの押込み量と硬さの関係 

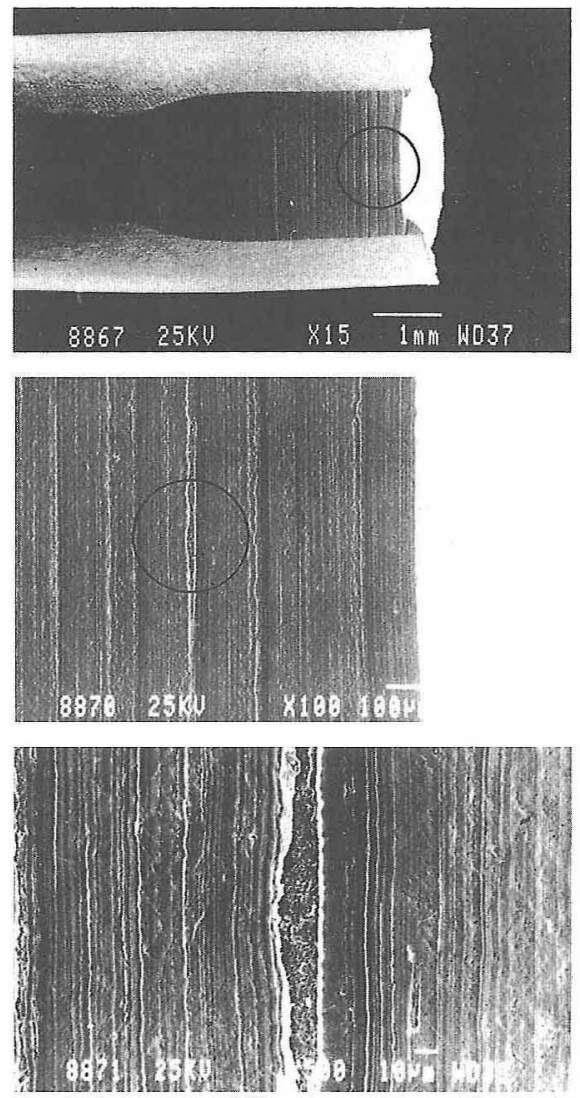

高強度鋼, ノッチ半径 $8 \mathrm{~mm}$

図 18 折損サンプルのノッチ部の走査型電子顕微鏡による観察例
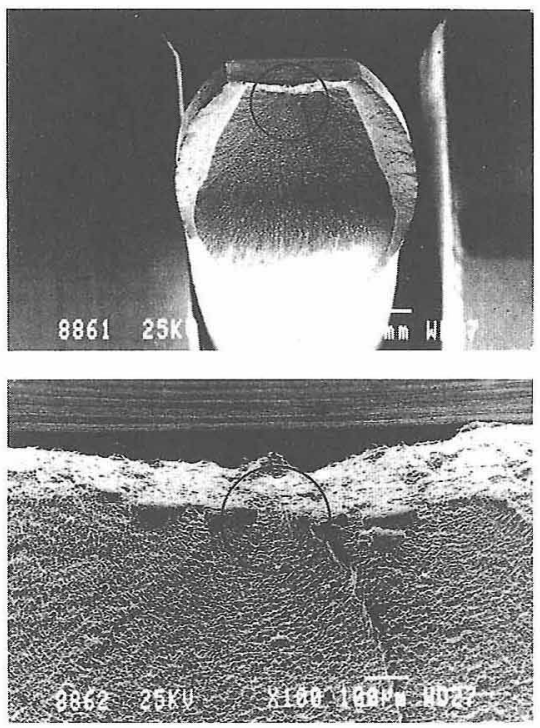

$\rightarrow+\infty 10+\infty$

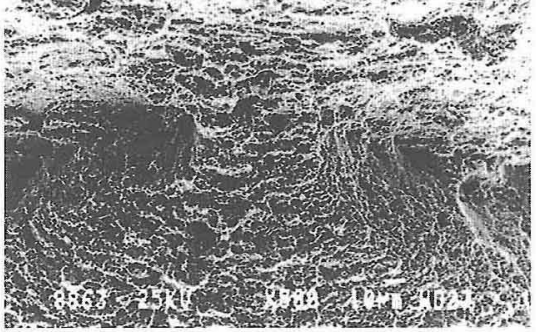

高強度鋼, ノッチ半径 $8 \mathrm{~mm}$
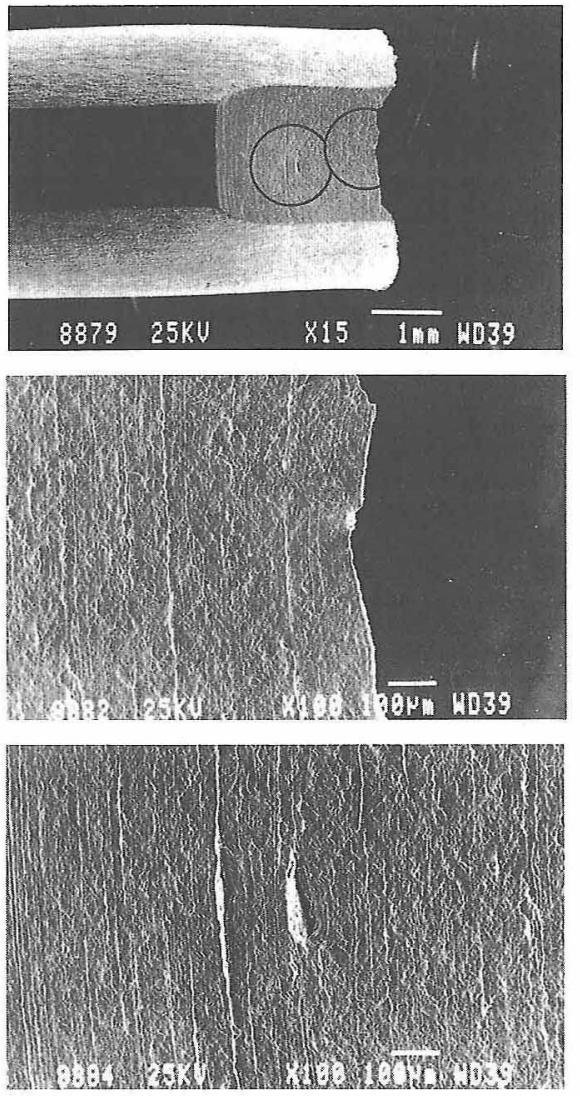

比較鋼，ノッチ半径 $2 \mathrm{~mm}$
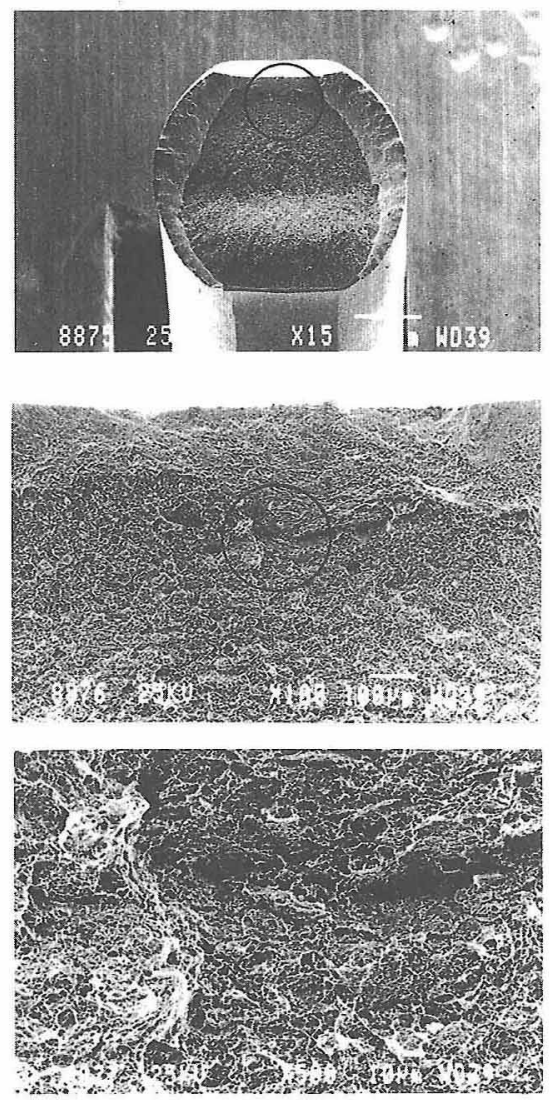

比較鋼，ノッチ半径 $2 \mathrm{~mm}$

図 19 折損サンプルの破面の走査型電子顕微鏡による観察例 


\section{2 加工性試験結果}

\subsection{1 ノッチ曲げ試験結果}

図 15 に，折損/未折損ノッチ半径と硬さの関係を示す。 図中の線は折損率 $50 \%$ ノッチ半径を示すが，これは各ポイン トでの折損率から推定したもので，有効範囲はほぼ図中に示 した領域である。強度が高くなると折損限界ノッチ半径が大 きくなる傾向にあるが，高強度鋼と比較鋼では折損限界に明 瞭な差が見られ，折損率 $50 \%$ ノッチ半径は高強度鋼の方が 大きい傾向，すなわち切欠き感受性が高いことが判った。

図 16 に最大荷重と硬さの関係を示す。未折損材では硬さ が高くなるに伴い最大荷重が高くなる傾向にある。折損材 ではノッチ半径が大きくなるほど最大荷重は大きくなる傾 向があり，硬さの高い高強度鋼の方が比較鋼に比べてノッ チ半径が大きいにもかかわらず小さな荷重で折損している。

表 18 自由長とコイル外径の平均值とばらつき（mm）

\begin{tabular}{c|c|c|c|c|c}
\hline 供試材 & \multirow{2}{*}{ 呼称 } & \multicolumn{2}{|c|}{ 自由長 } & \multicolumn{2}{c}{ コイル外径 } \\
\cline { 3 - 6 } & & $\overline{\mathrm{X}}$ & $\sigma_{\mathrm{n}-1}$ & $\overline{\mathrm{X}}$ & $\sigma_{\mathrm{n}-1}$ \\
\hline 高強度鋼 & $\mathrm{H} 21$ & 51.246 & 0.174 & 26.961 & 0.028 \\
\hline 高強度鋼 & $\mathrm{H} 20$ & 51.399 & 0.143 & 27.051 & 0.060 \\
\hline 比較 鋼 & $\mathrm{S} 20$ & 51.255 & 0.133 & 26.998 & 0.038 \\
\hline 比较 鋼 & $\mathrm{S} 19$ & 51.134 & 0.218 & 26.983 & 0.102 \\
\hline
\end{tabular}

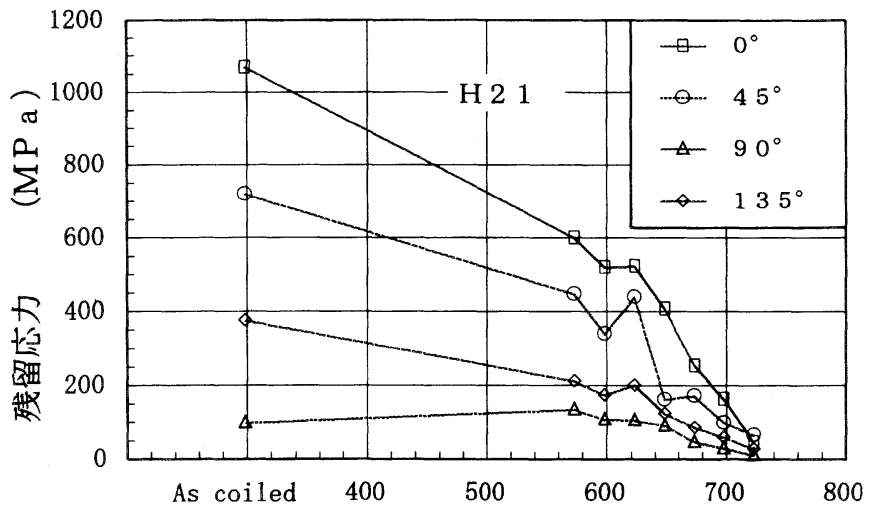

低温焼なまし温度

(K) $\times 25 \mathrm{~m} \mathrm{i} \mathrm{n}$

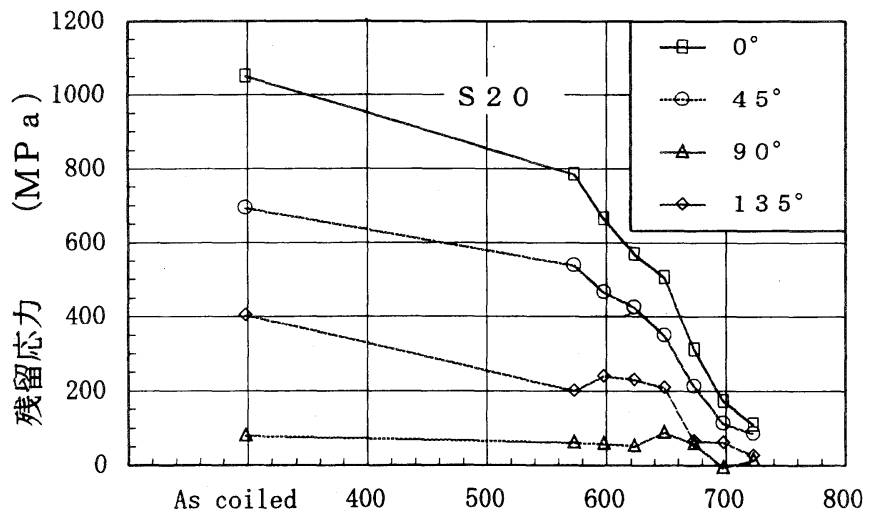

低温焼なまし温度
図 17 に折損に至るまでの押込み量と硬さの関係を示す。 最大荷重と同じく，高強度鋼の方が比較鋼に比べてノッチ半 径が大きいにもかかわらず小さな押込み量で折損している。

図 18 に折損サンプルのノッチ部，図 19 に破面の走査型 電子顕微鏡による観察例を示す。高強度鋼と比較鋼共に折 損サンプルはノッチ研削条痕を起点として折損しており， 折損部以外にも研削条痕に沿ったクラックが認められる。 また，高強度鋼，比較鋼ともに破面は延性破面である。

\subsection{2 コイリング性}

高強度鋼と比較鋼共に，コイリング時に割れ，きずなど の発生は認められずコイリング性は良好であった。また， 測定された自由長とコイル外径の平均值と標準偏差は 表 18 に示すとおりで鋼種及び強度による差は見られず，加工精 度の面でも問題はないことがわかる。

\section{3 加工ひずみ除去試験結果}

図20に高強度鋼と比較鋼の低温焼なまし温度とばね内 径側の残留応力との関係を示す。コイリング直後は $1000 \mathrm{MPa}$ 程度の大きな引張残留応力が作用しており，軸 線方向が最も大きな值を示している。なお，鋼種，強度に よる差はほとんどないようである。低温焼なまし温度の上 昇に伴って引張残留応力は急激に低下寸るが，軸線方向で みた場合，598Kの低温焼なまし後でも $600 \mathrm{MPa}$ 程度， $698 \mathrm{~K}$ の低温焼なまし後も $170 \mathrm{MPa}$ 程度の引張残留応力と なっている。

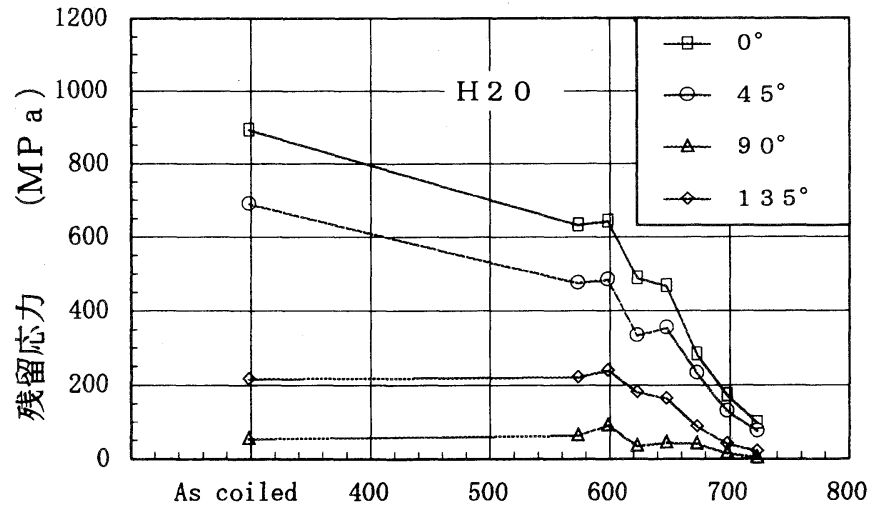

低温焼なまし温度 （K） $\times 25 \mathrm{~m} \mathrm{i} \mathrm{n}$

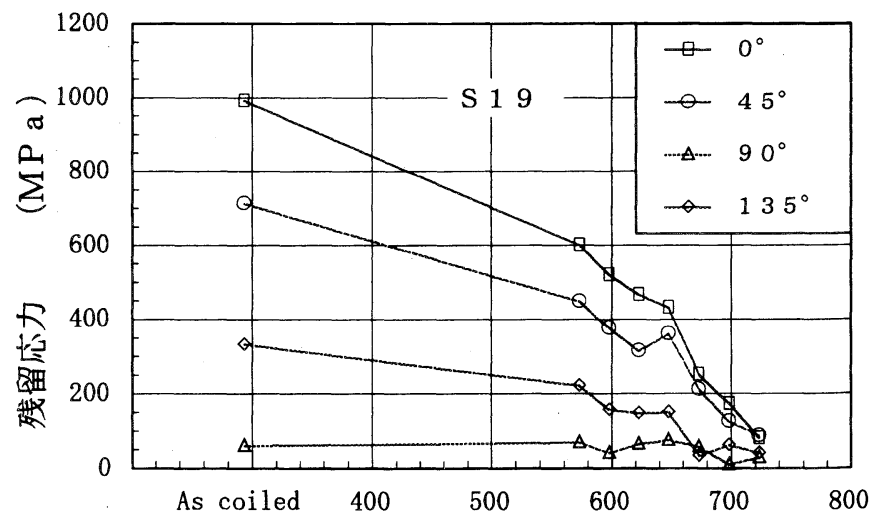

低温焼なまし温度 $\quad(\mathrm{K}) \times 25 \mathrm{~m}$ i n

図 20 ばね内径側の残留応力と低温焼なまし温度の関係 


\begin{tabular}{|l|c|c|c|}
\hline & 1次材 & 2次材 & 3次材 \\
\hline $\begin{array}{l}\text { 低温焼なまし } \\
\text { 温度(K) }\end{array}$ & 698 & \multicolumn{2}{|c|}{598} \\
\hline ショットピーシッグ & \multicolumn{2}{|c|}{ Single } & Double \\
\hline
\end{tabular}

\begin{tabular}{|c|c|c|c|}
\hline 鏩種 & $\begin{array}{l}\text { 強度レベル } \\
(\mathrm{MPa})\end{array}$ & 呼称 & 記号 \\
\hline \multirow{2}{*}{ 高強度鋼 } & 2100 & H21 & $\cdots$ \\
\hline & 2000 & $\mathrm{H} 20$ & $-\Delta$ \\
\hline \multirow{2}{*}{ 比較鎆 } & 2000 & $\mathrm{~S} 20$ & $\cdots \bullet$ \\
\hline & 1900 & S19 & 0 \\
\hline
\end{tabular}
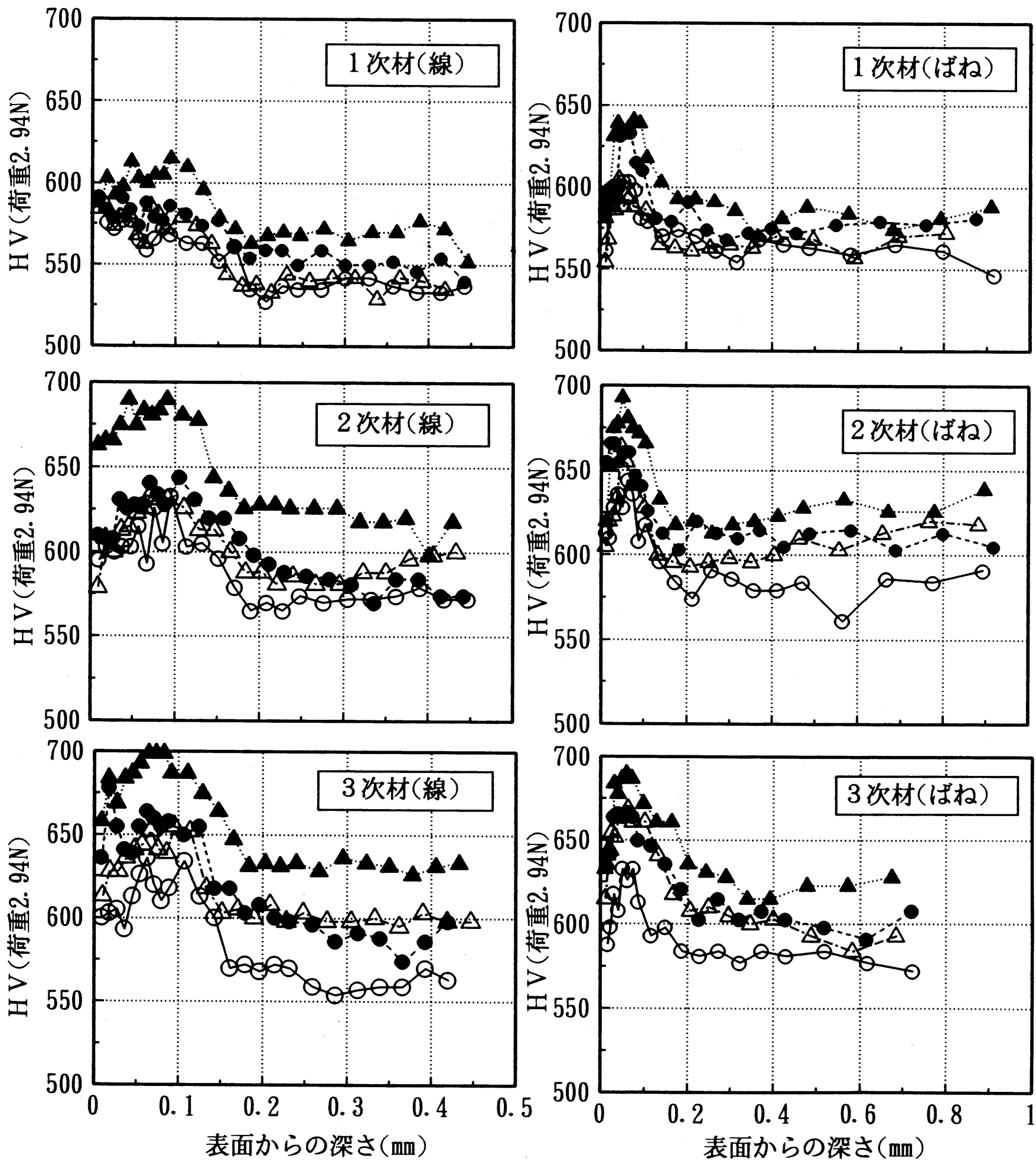

図 21 線表層部の硬さ分布 

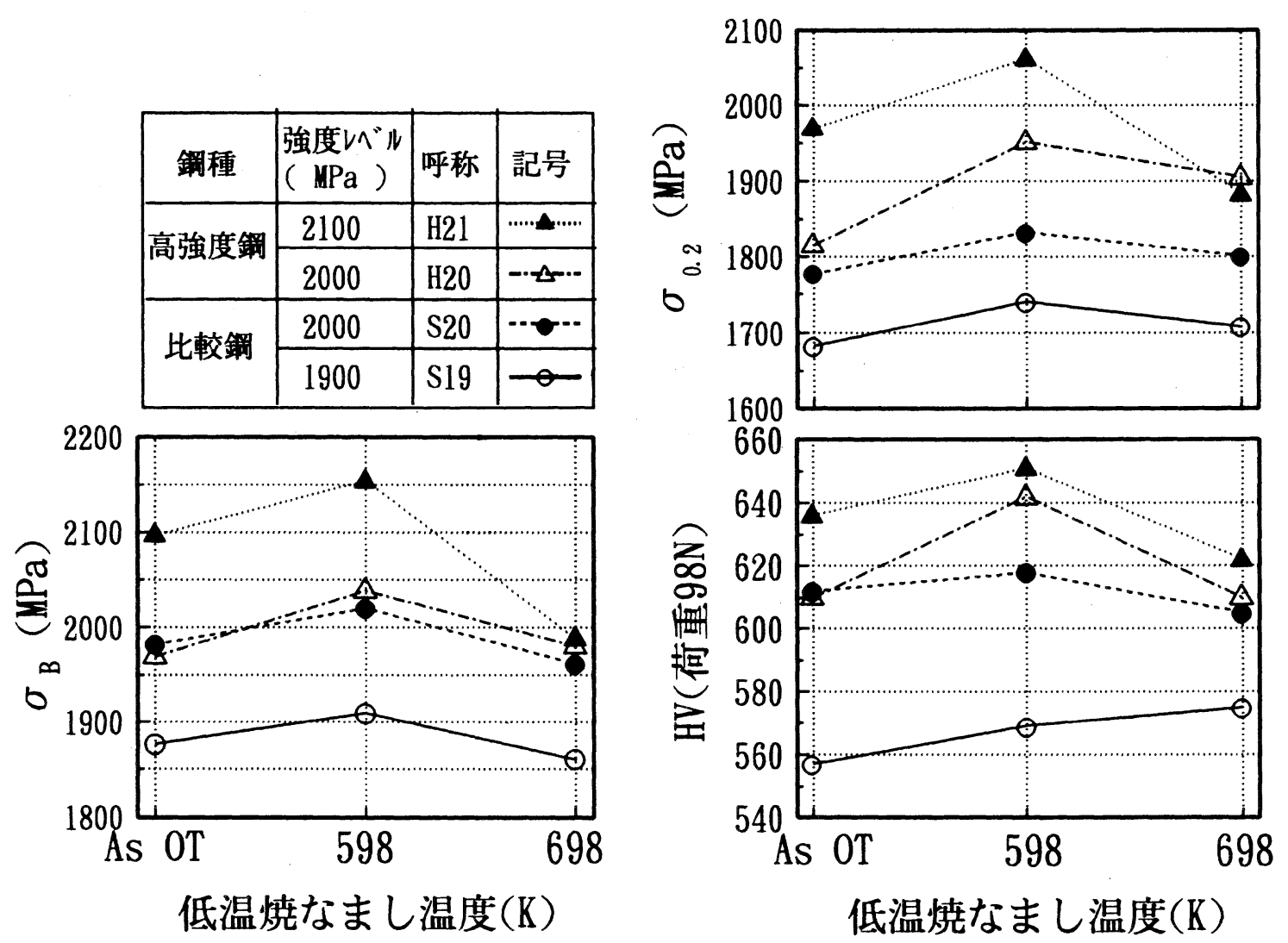

図 23 供試材の低温焼なまし特性（図 8 力ら抜粋）

\section{4 疲労試験用試料表層部の物性}

\subsection{1 硬さ分布}

低温焼なまし及びショットピーニングを施した線及びば ねの表層部の硬さ分布をそれぞれ 図21，図22 に示す。線 とばねで硬さの絶対值に若干差のあるデー夕も見られるが, 傾向的にはいずれの供試材も線とばねの硬さ分布によい対 応が認められた。ショットピーニングの影響により表面か ら $0.2 \mathrm{~mm}$ 深さの位置まで硬さの上昇があり， $0.1 \mathrm{~mm}$ 深さ の位置で硬さのピーク值が認められた。

低温焼なまし温度が高い (698K) 1 次材の場合, 供試材間 の硬さの差は余り大きくないが，低温焼なまし温度が $598 \mathrm{~K}$ の 2,3 次材の場合, 供試材間の硬さの差は大きく, H21> $\mathrm{H} 20=\mathrm{S} 20>\mathrm{S} 19$ の順になっていた。各供試材（線・ばね）の 表面から $0.2 \mathrm{~mm}$ 深さの位置より内部の硬さ值は, 図23で 示した供試 OT 線の各低温焼なまし温度の $H V$ あるいは $\sigma_{B}$ と対応している。

\subsection{2 残留応力分布}

線及びばねの表層部残留応力分布をそれぞれ 図 24, 図 25 に示す。残留応力の測定のばらつきを考慮すれば，線の 残留応力は，表面及び内部に扔いて各供試材間及び $1 \sim 3$ 次材間に大きな差はなく，鋼種，As OT 強度，低温焼なま し温度及びショットピーニングの差の影響は顕著には認め られなかった。

ばね内側の残留応力も，線の場合と同様に供試材間で余 り大きな差は認められなかった。ただし，2次材及び 3 次 材のばねの場合は残留応力值が圧縮から引張に変化するク
ロッシング・ポイント深さが素線硬さに反比例して若干浅 くなる傾向が認められた。

\subsection{3 表面粗さ}

線及びばねの表面粗さ測定結果をそれぞれ 図 26, 図 27 に示す。

線の場合は 1 ～次材では H 21 の粗さが若干小さいが, ダブル・ショットピーニングの 3 次材では供試材間に差が認 められなかった。ばねの場合は特に顕著な傾向は認められず, いずれのばねも $R_{\max }$ で $6 \sim 10 \mu \mathrm{m}, R_{z}$ で $5 \mu \mathrm{m}$ 前後であった。

\section{5 線の回転曲げ疲労試験結果}

ステアケース法による線の回転曲げ疲労試験結果を 付図 $1 \sim 6$ に，また介在物による折損率を 付表 1 に示す。これ らのデー夕を用いて，鋼種，引張強さ及び処理条件と疲労 寿命の関係，引張強さや処理条件と介在物折損の関係等に ついて比較検討した。

\subsection{1 鋼種, 引張強さ及び処理条件と疲労寿命の関係}

低温焼なまし後の引張強さと $10^{7}$ 回に打ける時間強度の平 均值 $S \hat{n}$ の関係を, 試験担当会社別に表 19 及び図 28 に示 した。これらから，各社間に差があり最も差の大きいもので は 1 次材で比較鋼 S20 の場合で $65 \mathrm{MPa}$ の差が生じていること がわかる。さらに，各社の傾向をみると，いずれも引張強 さに比例して $\hat{\text { n }}$ が高くなっているが， 3 次材の高強度鋼を 担当した 1 社であまり差のない結果となっている。また， 表 11 で示したように，同一供試材を 2 社あるいは 3 社で 担当しており，平均值でみるのは問題があるが，全体の傾 


\begin{tabular}{|c|c|c|c|}
\hline & 1次材 & 2次材 & 3次材 \\
\hline $\begin{array}{l}\text { 低温焼なまし } \\
\text { 昷度(K) }\end{array}$ & 698 & & 598 \\
\hline ショット゚ーニッが & \multicolumn{3}{|c|}{ Single } \\
\hline
\end{tabular}

\begin{tabular}{|c|c|c|c|}
\hline 鋼種 & $\begin{array}{l}\text { 強度 } レ ヘ ゙ ル \\
(\mathrm{MPa})\end{array}$ & 呼称 & 記号 \\
\hline \multirow{2}{*}{ 高強度釷 } & 2100 & $\mathrm{H} 21$ & 4 \\
\hline & 2000 & $\mathrm{H} 2 \mathrm{O}$ & $-\Delta$ \\
\hline \multirow{2}{*}{ 比較鎆 } & 2000 & S20 & $\cdots \cdots$ \\
\hline & 1900 & S19 & 0 \\
\hline
\end{tabular}
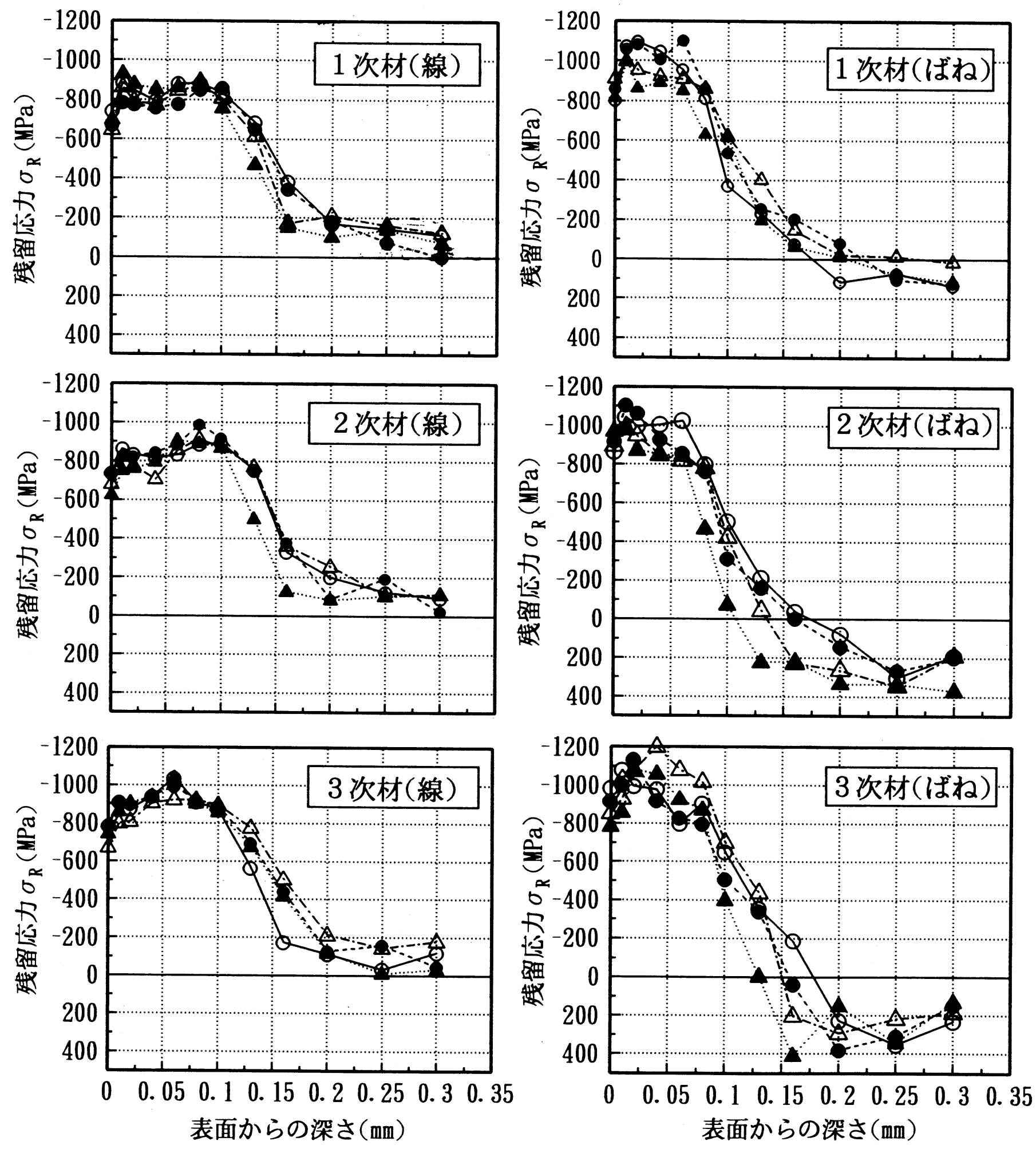

表面からの深さ $(\mathrm{mm})$

図 24 線表層部の残留応力分布

図 25 ばね表層部の残留応力分布 （ばね内側） 


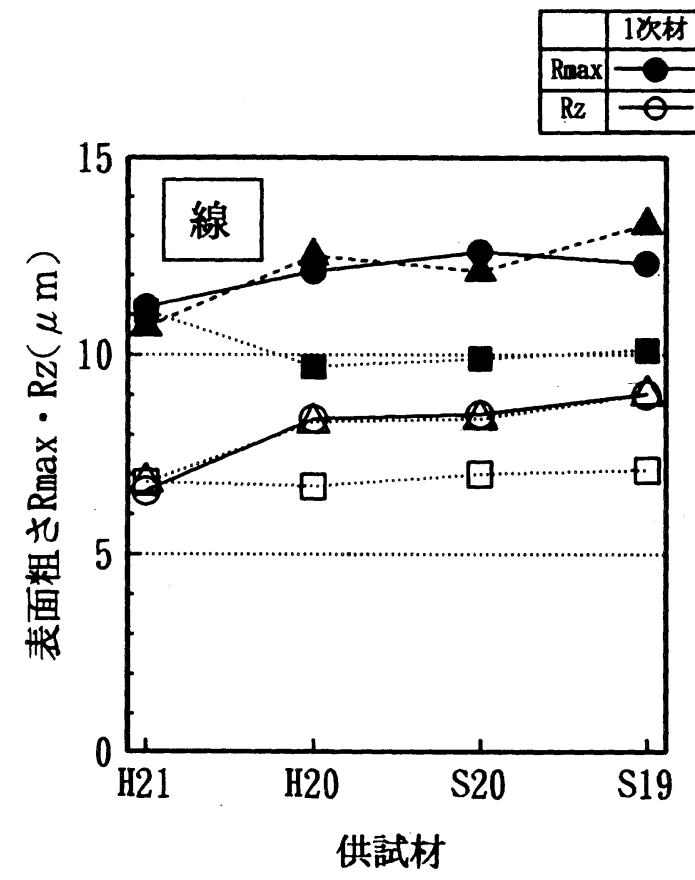

図 26 線の表面粗さ

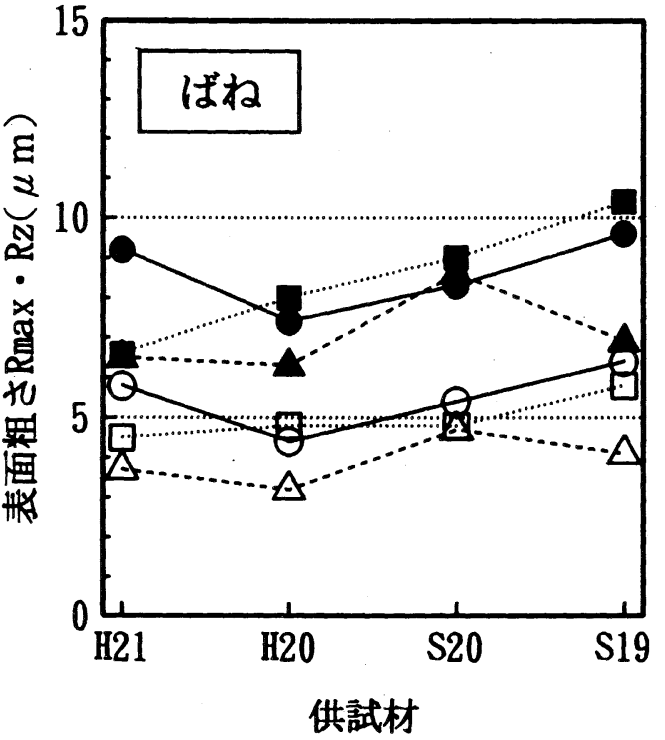

図27ばねの表面粗さ （ばねの内側）

表 19 線の回転曲げ疲労試験結果

\begin{tabular}{|c|c|c|c|c|c|c|c|c|c|c|}
\hline \multirow[t]{2}{*}{ 処 理 } & \multirow[t]{2}{*}{ 第種 } & \multirow{2}{*}{ 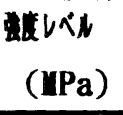 } & \multirow[t]{2}{*}{ 呼称 } & \multirow{2}{*}{ 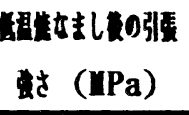 } & \multicolumn{6}{|c|}{$10^{7}$ 回における村久限, $\hat{\mathrm{Sn}}(\mathrm{YPa})$} \\
\hline & & & & & $\mathbf{A} \#$ & I椾 & H保 & C\# & 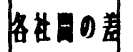 & $\overline{\mathbf{x}}$ \\
\hline \multirow{4}{*}{ 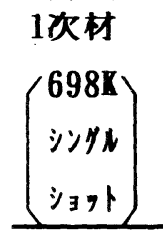 } & \multirow[t]{2}{*}{ 高強度金 } & 2100 & H21 & 1989 & 937 & 966 & - & - & 29 & 952 \\
\hline & & 2000 & H2O & 1981 & 914 & 957 & 898 & - & 59 & 923 \\
\hline & \multirow[t]{2}{*}{ 比等 } & 2000 & S20 & 1961 & 947 & - & 926 & 991 & 65 & 955 \\
\hline & & 1900 & S19 & 1862 & 925 & - & - & 949 & 24 & 937 \\
\hline \multirow{4}{*}{ 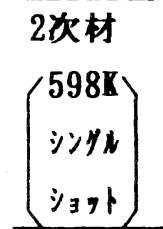 } & \multirow[t]{2}{*}{ 高強度全 } & 2100 & н21 & 2154 & 964 & 988 & - & - & 24 & 976 \\
\hline & & 2000 & н20 & 2039 & 950 & 974 & 956 & - & 24 & 960 \\
\hline & \multirow[t]{2}{*}{ 比弶 } & 2000 & s20 & 2020 & 961 & - & 972 & 991 & 30 & 975 \\
\hline & & 1900 & S19 & 1909 & 932 & - & - & 982 & 50 & 957 \\
\hline \multirow{4}{*}{$\left.\begin{array}{l}3 \text { 次材 } \\
598 \mathrm{~K} \\
4 \neq k \\
\dot{y}_{3}\end{array}\right)$} & \multirow[t]{2}{*}{ 高強度箱 } & 2100 & H21 & 2154 & 1004 & 1006 & - & - & 2 & 1005 \\
\hline & & 2000 & H20 & 2039 & 1006 & 989 & 955 & - & 51 & 983 \\
\hline & \multirow[t]{2}{*}{ 比较会 } & 2000 & S20 & 2020 & 1013 & - & 1007 & 1015 & 8 & 1012 \\
\hline & & 1900 & S19 & 1909 & 984 & - & - & 1011 & 27 & 998 \\
\hline
\end{tabular}



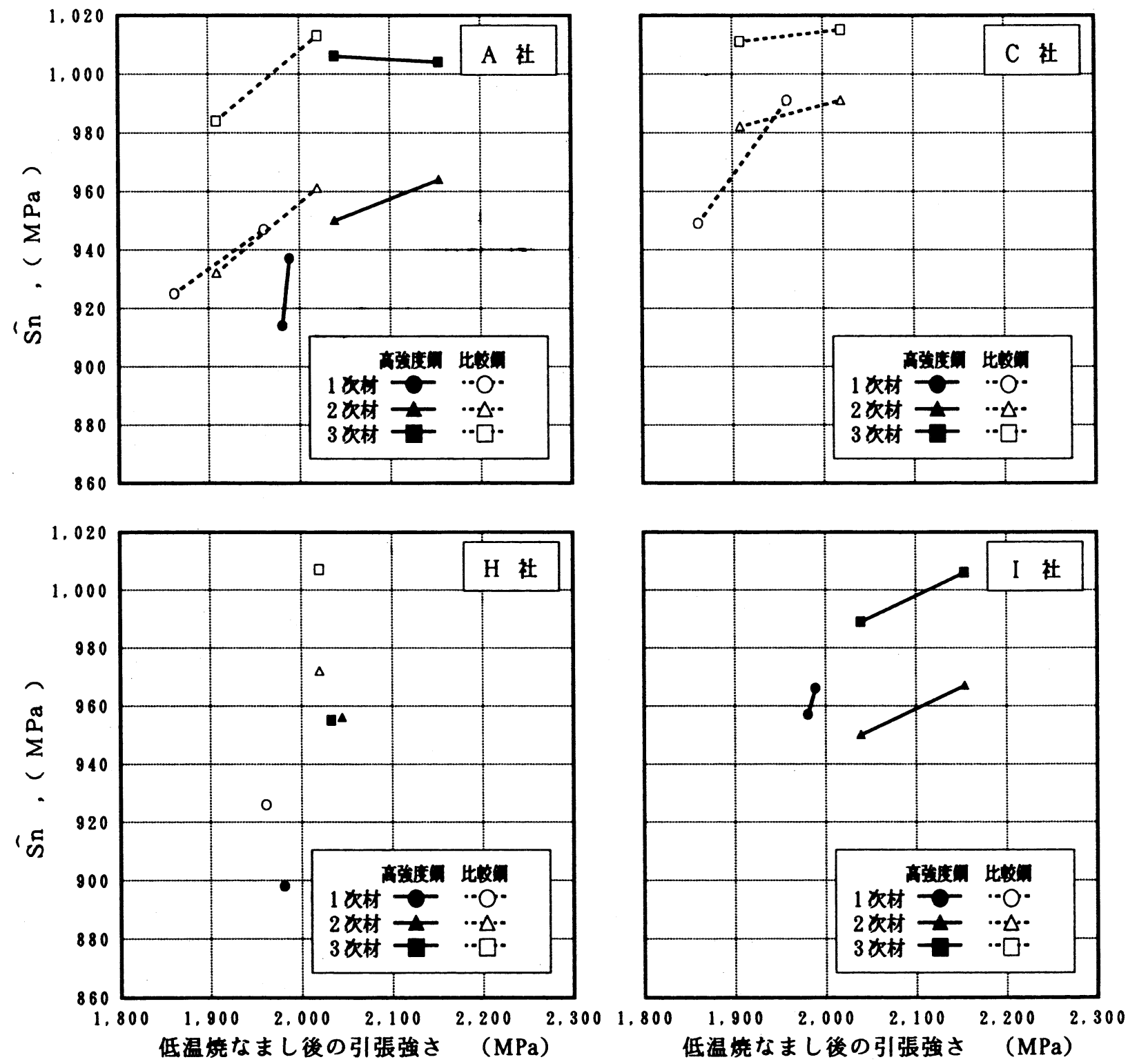

図 28 低温焼なまし後の引張強さと $\hat{S n}$ の関係（試験担当メーカ別）

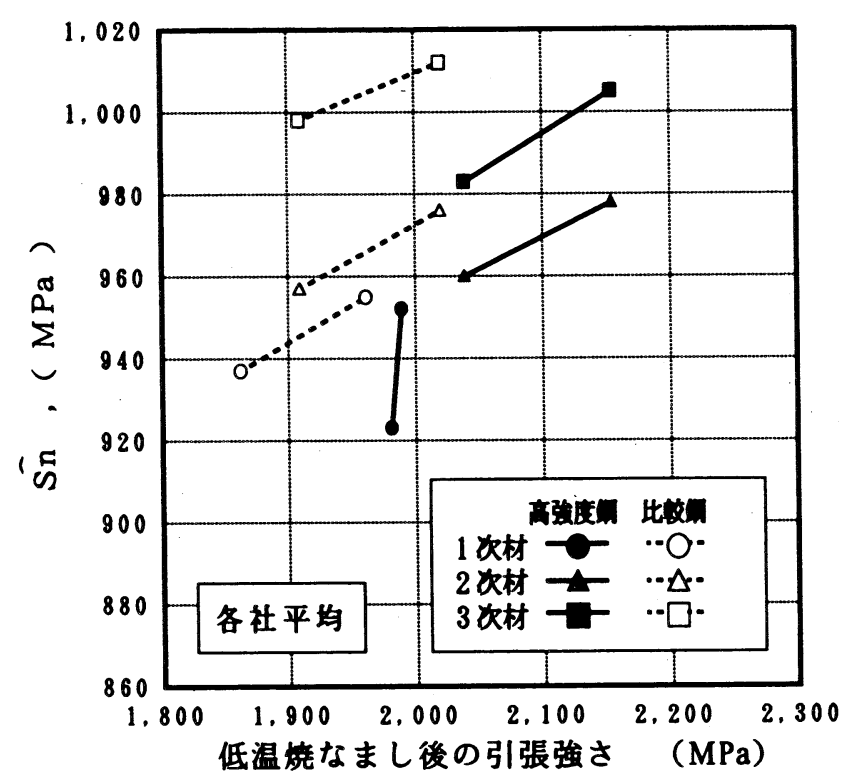

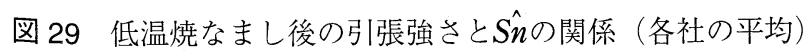

向としてみると図29のようになる。これから高強度鋼の 1 次材は引張強さに対する $\hat{S n}$ の上昇率が著しく, 2 次材及 び 3 次材と勾配が異なるが，いずれも引張強さの増大とと もに $\hat{S n}$ 值も増大しており, 1 次材より 2 次材, 2 次材より 3 次材と順次 $S \hat{n}$ が高くなっていることがわかる。また, 各 処理材とも高強度鋼のほうが比較鋼に比べ引張強さが高い にもかかわらず, $\hat{S n}$ のレベルが低くなって高強度化の効果 が出ていないことがわかる。

さらに，供試材の処理条件と $\hat{S n}$ の関係を各社別に図 30 に示した。各社とも若干の例外はあるが，1次材，2次材， 3 次材の順に $\hat{S n}$ は上昇している。また, 図 31 に平均值で みた処理条件と $\hat{S n}$ の関係を示す。いずれの供試材も, 同一 ショットピーニングで低温焼なまし温度のみ異なる 1 次材 と 2 次材の差は, 引張強さが影響して 2 次材の $S \hat{n}$ が高くな っている。また, 同一低温焼なまし温度でショットピーニ ング条件のみ異なる 2 次材と 3 次材の差は, ダブルピーニ

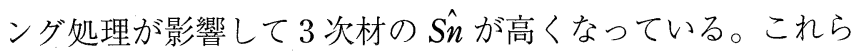



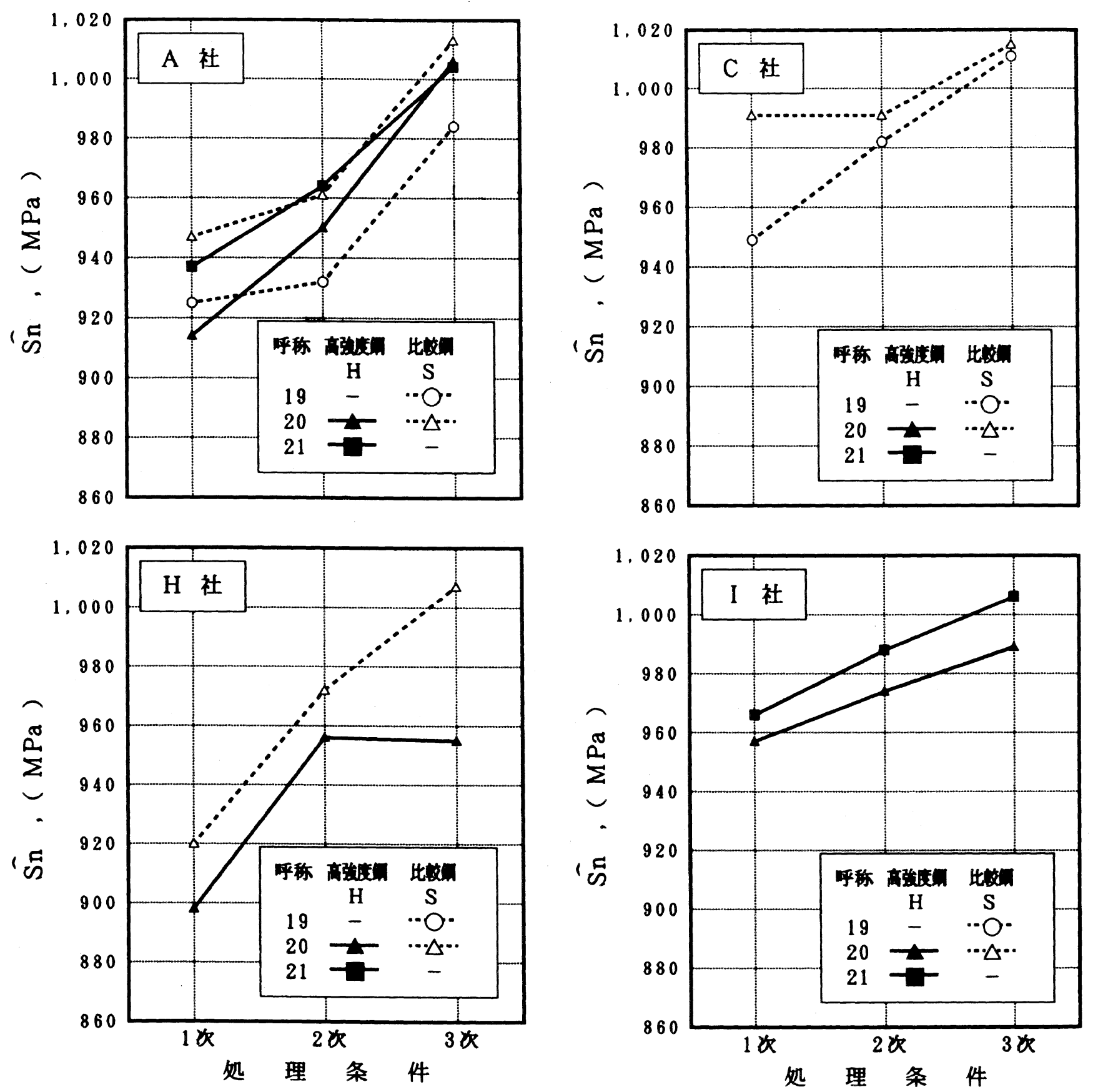

図 30 Snにに及ぼす処理条件の影響（試験担当メーカ別）

から, オイルテンパー後の後処理条件が疲労寿命に大きく 影響することがわかる。

\subsection{2 折損破面の状況}

折損した破面から，起点の介在物の有無を調査した。こ のうち折損状況，破面の外観及び起点の種類等の代表的な 例を図32に，また，図 33 に先の図 32 のうち起点となっ た介在物の形状及び大きさを拡大して示した。

特に，介在物の影響が強度レベルに依存していることか ら，介在物による折損率と低温焼なまし後の引張強さの関 係を図34に示した。これから，いずれの供試材も引張強さ とともに介在物による折損率が増加していることがわかる。 また，同じ強度レベル $(\mathrm{S} 20$ と H 20$)$ でみると，1次材及び 3
次材については差がないが，2次材は高強度鋼の方が介在 物による折損率が低い。

次に処理条件との関係をみると，図35になる。これから， 高強度鋼, 比較鋼ともオイルテンパー時で強度レベルをあ げたものほど折損率が高くなることがわかる。また，処理 条件では 1 次材, 2 次材, 3 次材の順に折損率が高くなる傾 向にあるが，3 次材では，2次材に比べ高くなるものと低く なるものとがある。

4.5.3 中村式回転曲げ疲労試験の各社間の機差につ いてく参考 $>$

線の回転曲げ疲労試験の場合, 従来共同研究の例もなく, 試験方法も統一されていない現状から, 本委員会では試験 
に先立ち機差の現状を把握するため，参加各社のうち本試 験機を設置している12社で同一試料を用いて先の表 12 に示 した条件で試験を行い, 結果を比較した。また, 試験本数 は 20 本とし，ブッシュは試験本数が多いことから各社で準 備した。

（1）供試材の化学成分及び機械的性質

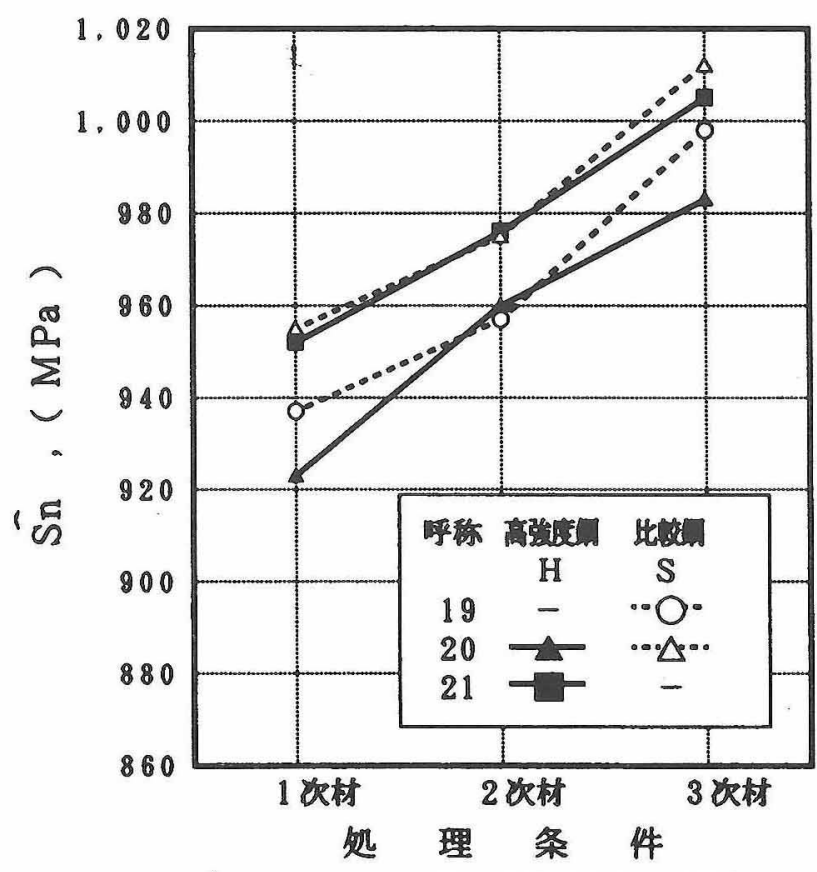

図31 Sñに及ぼす処理条件の影響（各社の平均）
表 20 に，機械的性質を 表21に示す。また，供試材の低温 焼なまし、ショットピーニングなどは図 36 によった。

(2) 試験結果

図 37 に $10^{7}$ 回に㧈ける耐久限の平均值 $S \hat{n}$ と標準偏差 $\sigma$ を

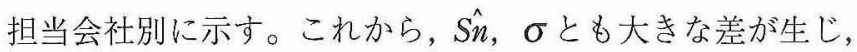
耐久限の平均值 $S \hat{n}$ では $73 \mathrm{MPa}$ の差が, 標準偏差 $\sigma$ では最 大と最小の比が7.8倍もあった。

\section{6 ばねの疲労試験結果}

ばねの疲労試験結果を末尾の 付図 7〜14 に示す。これら の結果に基づいて，BANEXを用いて累積ハザード法 ${ }^{10)} に$ 上る統計処理を行い, 鋼種, 引張強芑, 処理条件等と疲労 寿命との関係について比較検討を行った。累積ハザード法 による統計処理結果を 表 22, 表 23, 図 38 及び 図 39 に示 す。未折損品の残留せん断ひずみは，図 40 及び図 41 に示 す。

\subsection{1 鋼種, 引張強さと疲労寿命の関係}

処理条件の違いを問わず，『S $19=\mathrm{S} 20<\mathrm{H} 20=\mathrm{H} 21 』 の$ 順 で疲労寿命が増大している。図42は，ばねと同じ条件の低 温焼なましした材料の引張強さと疲労寿命の関係を示した ものである。すなわち，鋼種では高強度鋼が比較鋼に比べ 優れているが，同一鋼種内では引張強さの疲労寿命への影 響はほとんどない。

\subsection{2 処理条件と疲労寿命の関係}

鋼種, 引張強さを問わず, 『2 次材 $<3$ 次材 $<1$ 次材』の 順で疲労寿命が長くなっている。引張強さの大きい 2 次及

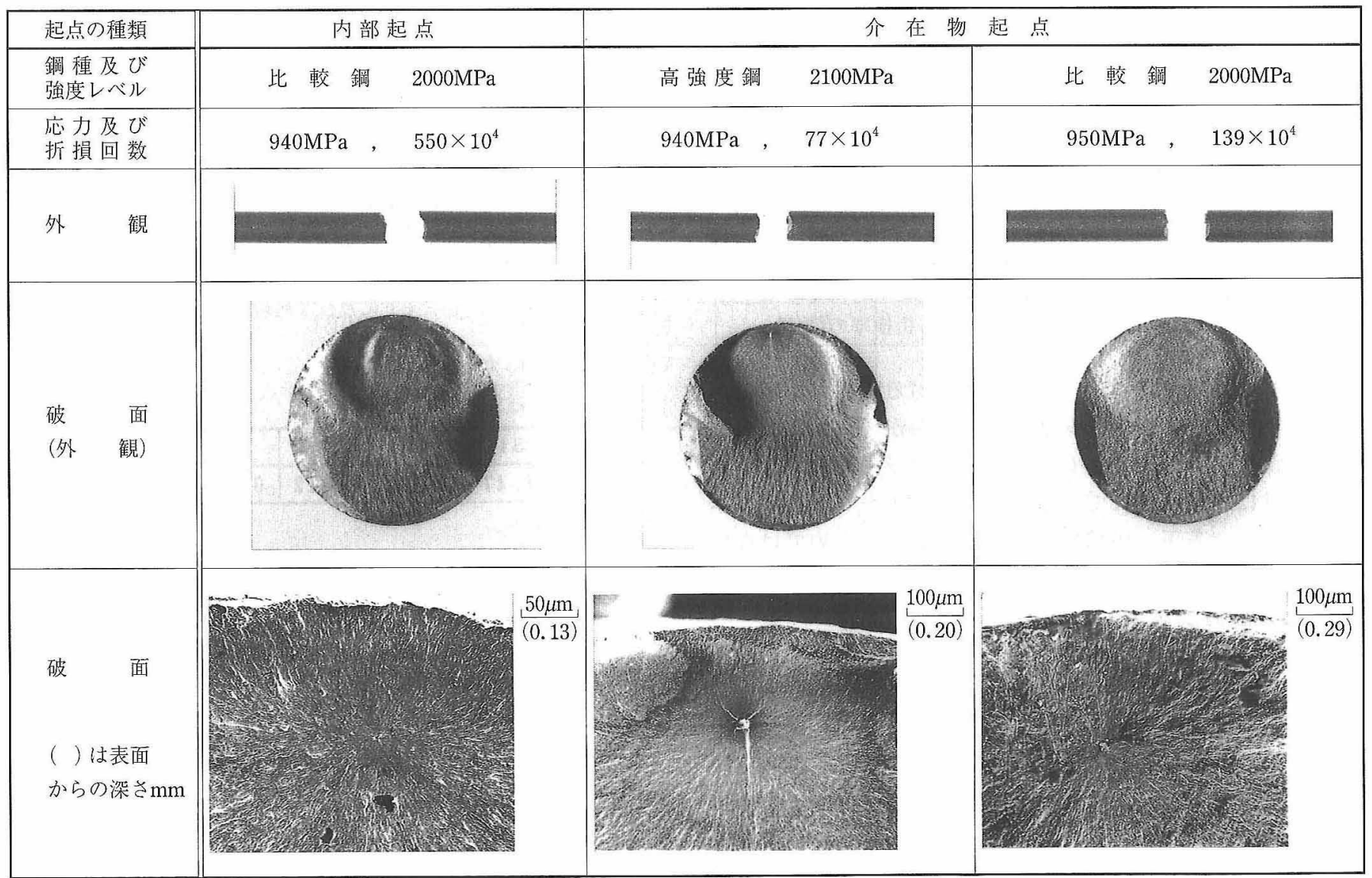

図 32 代表的な破面例 


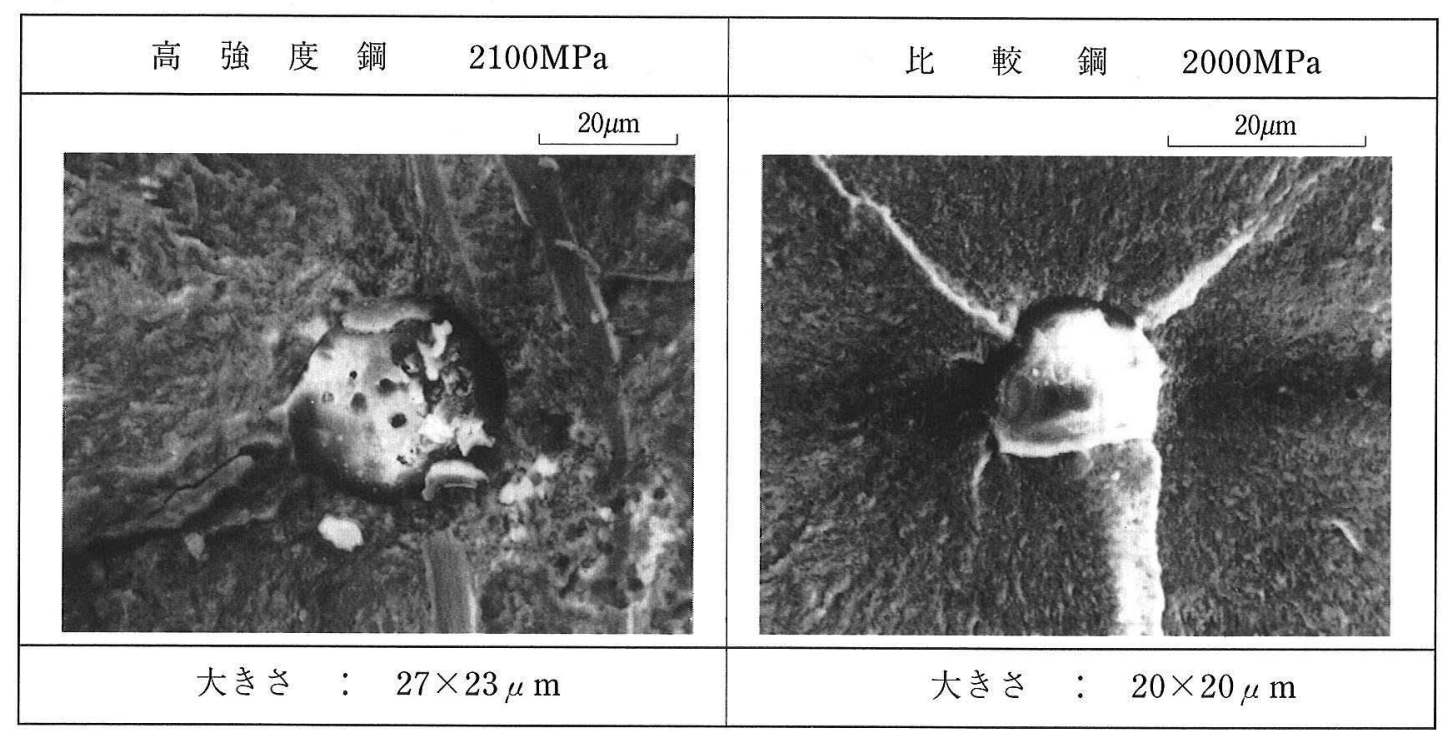

図33 介在物の形状と大きさ

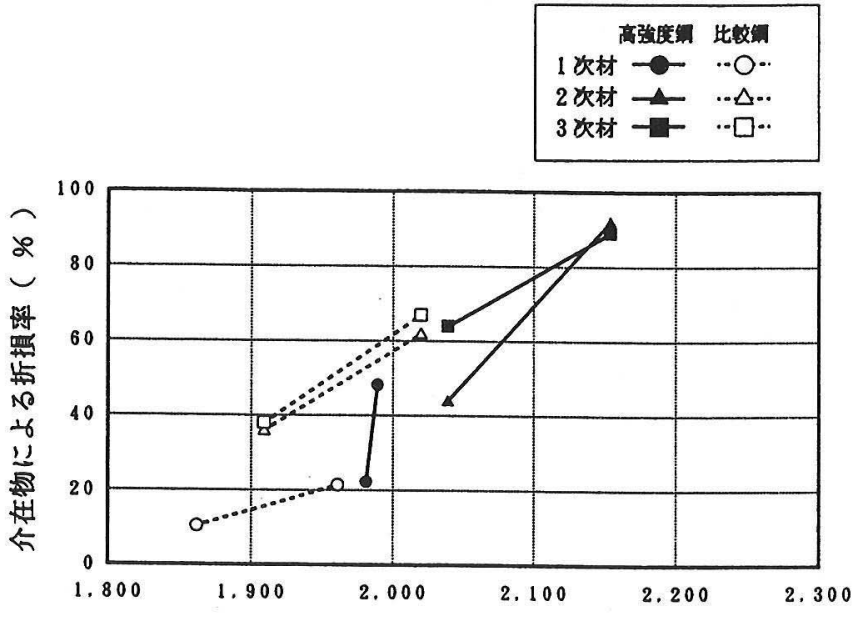

低温焼なまし後の引張強さ（MPa）

図 34 引張強さと介在物起点による折損率の関係

び 3 次材が 1 次材に対して疲労寿命が劣る理由は不明であ るが, クロッシングポイント（残留応力が圧縮から引張に 変わる深さ）が浅いことによる影響が考えられる。3次材 が 2 次材に対して優れているのは，ダブルショットピーニ ングの効果で若干，圧縮残留応力が増加したためではない かと思われる。

\subsection{3 疲労試験機の形式と疲労寿命の関係}

駆動形式がカム駆動と油圧サーボの異なる 2 種類の試験 機で疲労試験を行なったが，どちらの試験機でも『鋼種及 び引張強さと㾉労寿命の関係』は同じであった。両試験機 による寿命の差については，サンプル数が異なるので一律 には比較できないが，入力波形が同じ正弦波であり振幅一 定の試験のため，差はないと思われる。

\subsection{4 平均応力と疲労寿命の関係}

図39 の平均応力と疲労寿命の関係において, 比較鋼で平

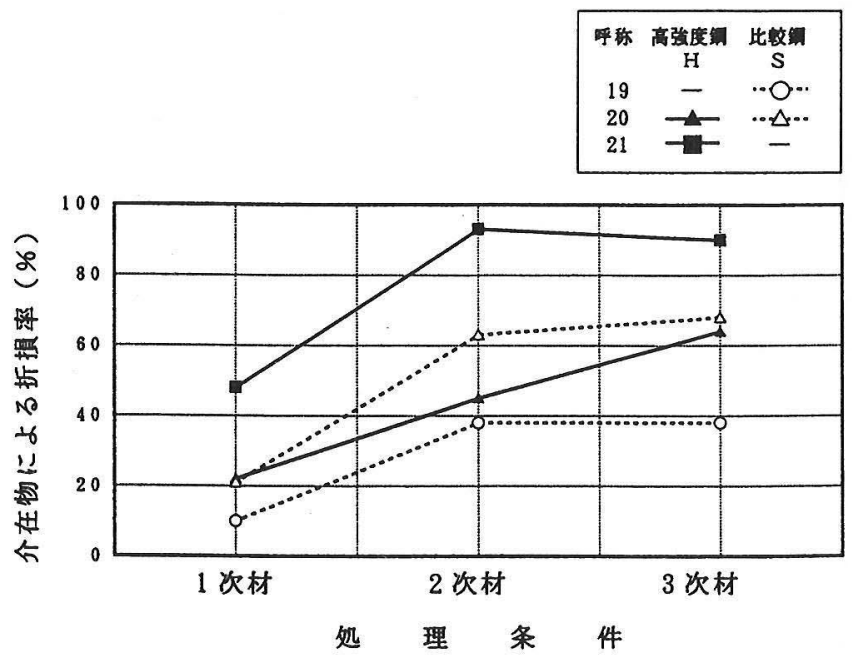

図 35 折損率 (介在物よる) に及ぼす処理条件の影響（各社の平均）

表 20 機差検討用供試材の化学成分（mass\%)

\begin{tabular}{c|c|c|c|c|c|c}
\hline $\mathrm{C}$ & $\mathrm{Si}$ & $\mathrm{Mn}$ & $\mathrm{P}$ & $\mathrm{S}$ & $\mathrm{Cu}$ & $\mathrm{Cr}$ \\
\hline 0.57 & 1.47 & 0.72 & 0.012 & 0.004 & 0.01 & 0.70 \\
\hline
\end{tabular}

表 21 機差検討用供試材の機械的性質

\begin{tabular}{|c|c|c|c|}
\hline 引 張 & 性 & じり & 特 \\
\hline$(\mathbf{M P a})$ & 1938 & $(\mathrm{MPa})$ & 1172 \\
\hline$\sigma_{0.2}$ & 1705 & $\tau_{\mathbf{0} .3}$ & 1019 \\
\hline$\sigma_{0.05} \quad(\mathrm{MPa})$ & 1556 & $\tau_{0.03} \quad(\mathrm{MPa})$ & 875 \\
\hline$\sigma_{0.2} / \sigma_{\text {в }}$ & 0.88 & $\tau_{\text {о. }}$; $/ \tau_{\text {в }}$ & 0.87 \\
\hline$(\mathrm{MPa})$ & 194,750 & ( $\mathbf{M P a})$ & 74,830 \\
\hline (\%) & 6.7 & $\operatorname{Tn}(100 \mathrm{~d}$, 回) & 17 \\
\hline (\%) & 52.1 & $\tau_{\text {в }} / \sigma_{\text {в }}$ & 0.60 \\
\hline
\end{tabular}




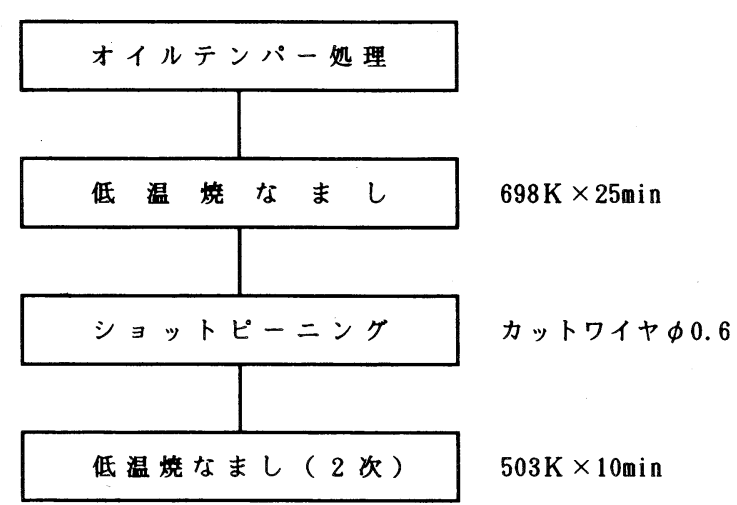

図 36 機差検討用供試材の低温焼なまし，

ショットピーニング条件

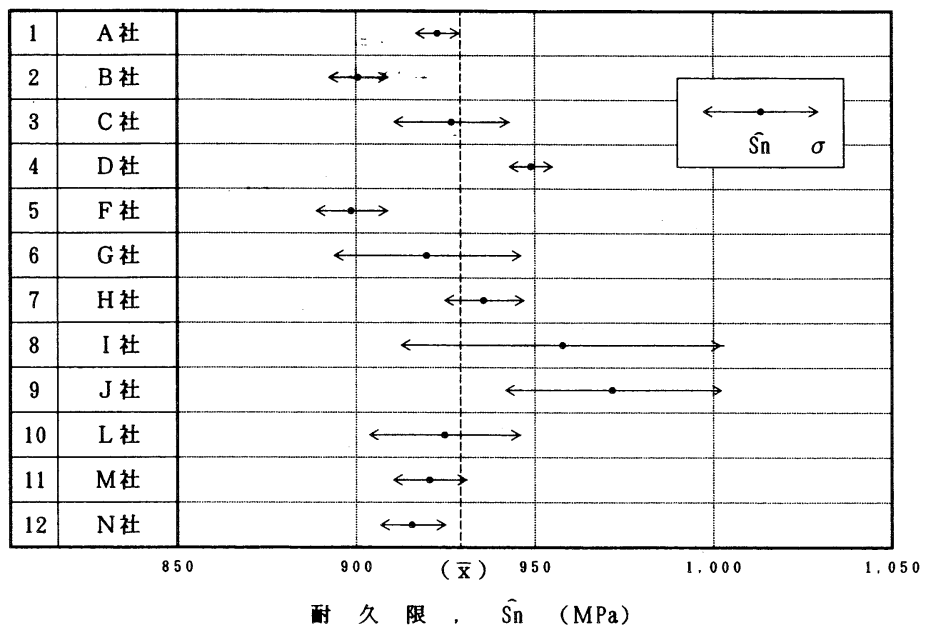

図 37 各社の中村式回転曲げ疲労試験の耐久限（平均值） とばらつき

表 22 累積ハザード法による統計処理結果（ $\tau_{m}=600 \mathrm{MPa} \quad 50 \%$ 破壊確率のばねの疲労寿命 $)$

\begin{tabular}{|c|c|c|c|c|c|c|}
\hline \multirow{3}{*}{ 種 } & \multirow{3}{*}{$\begin{array}{c}\text { 強度 } V \wedge(\mathbf{N P a}) \\
\text { (呼称) }\end{array}$} & \multirow{3}{*}{ 処 理 } & \multirow{2}{*}{\multicolumn{2}{|c|}{$\begin{array}{c}\text { 星型麦労試検機 } \\
\left(\times 10^{6} \text { 目 }\right) \\
\end{array}$}} & \multirow{2}{*}{\multicolumn{2}{|c|}{ 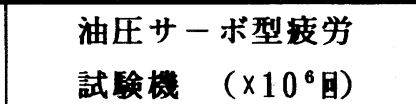 }} \\
\hline & & & & & & \\
\hline & & & $\tau \mathrm{a}= \pm 525 \mathrm{MPa}$ & $\tau \mathrm{a}= \pm 500 \mathrm{~Pa}$ & $\tau \mathrm{a}= \pm 525 \mathrm{PPa}$ & $\tau \mathrm{a}= \pm 500 \mathrm{~Pa}$ \\
\hline \multirow{6}{*}{ 高強度鎆 } & \multirow{3}{*}{$\begin{array}{l}2100 \\
\text { (H21) }\end{array}$} & 1次材 & 7.27 & - & 3.60 & 7.19 \\
\hline & & 2次材 & 1.94 & 4.66 & 2.41 & 5.08 \\
\hline & & 3次材 & 3.22 & 6.37 & 2.48 & 6.41 \\
\hline & \multirow{3}{*}{$\begin{array}{l}2000 \\
(\mathrm{H} 20)\end{array}$} & 1次材 & 5.37 & 14.70 & 3.20 & 6.58 \\
\hline & & 2次材 & 2.02 & 4.88 & 2.75 & 6.25 \\
\hline & & 3次材 & 3.04 & 6.46 & 4.87 & 7.76 \\
\hline \multirow{6}{*}{ 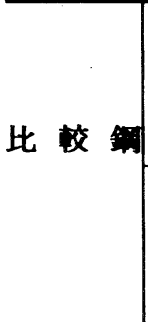 } & \multirow{3}{*}{$\begin{array}{l}2000 \\
(\mathrm{~S} 20)\end{array}$} & 1次材 & 1.81 & 3.89 & 2.19 & 4.48 \\
\hline & & 2次材 & 1.02 & 1.79 & 1.36 & 2.04 \\
\hline & & 3次材 & 1.53 & 2.44 & 2.61 & 3.46 \\
\hline & \multirow{3}{*}{$\begin{array}{l}1900 \\
(\mathrm{~S} 19)\end{array}$} & 1次材 & 2.04 & 4.05 & 2.69 & 7.65 \\
\hline & & 2次材 & 0.97 & 1.51 & 1.34 & 2.74 \\
\hline & & 3次材 & 1.30 & 2.56 & 1.89 & 3.20 \\
\hline
\end{tabular}

表 23 累積ハザード法による統計処理結果（ $\tau_{m}=550,700 \mathrm{MPa} \quad 50 \%$ 破壞確率のばねの疲労寿命 $)$

\begin{tabular}{|c|c|c|c|c|c|c|}
\hline \multirow[t]{2}{*}{ 鐡㮔 } & \multirow{2}{*}{$\begin{array}{c}\text { 強度 } レ \wedge ゙(\mathbf{M P a}) \\
\text { (呼称) }\end{array}$} & \multirow[t]{2}{*}{ 处 理 } & \multicolumn{2}{|c|}{$\tau=550 \mathrm{MPa}\left(\times 10^{6} \mathrm{G}\right)$} & \multicolumn{2}{|c|}{$\tau=700 \mathrm{MPa}\left(\times 10^{6}\right.$ 日) } \\
\hline & & & $\tau \mathrm{a}= \pm 525 \mathrm{~Pa}$ & $\tau \mathrm{a}= \pm 500 \mathrm{~Pa}$ & $\tau \mathrm{a}= \pm 525 \mathrm{MPa}$ & $\tau \mathrm{a}= \pm 500 \mathrm{Ma}$ \\
\hline \multirow[t]{2}{*}{ 高強度銅 } & 2100 (Н21) & 1次材 & 10.12 & - & 2.24 & 5.01 \\
\hline & 2000 (H20) & 1次材 & 6.95 & 15.27 & 1.73 & 4.05 \\
\hline \multirow[t]{2}{*}{ 比笠金 } & $2000(\mathrm{~S} 20)$ & 1次材 & 4.36 & 9.01 & 1.85 & 3.81 \\
\hline & 1900 (S19) & 1次材 & 4.59 & 8.91 & 1.69 & 3.45 \\
\hline
\end{tabular}




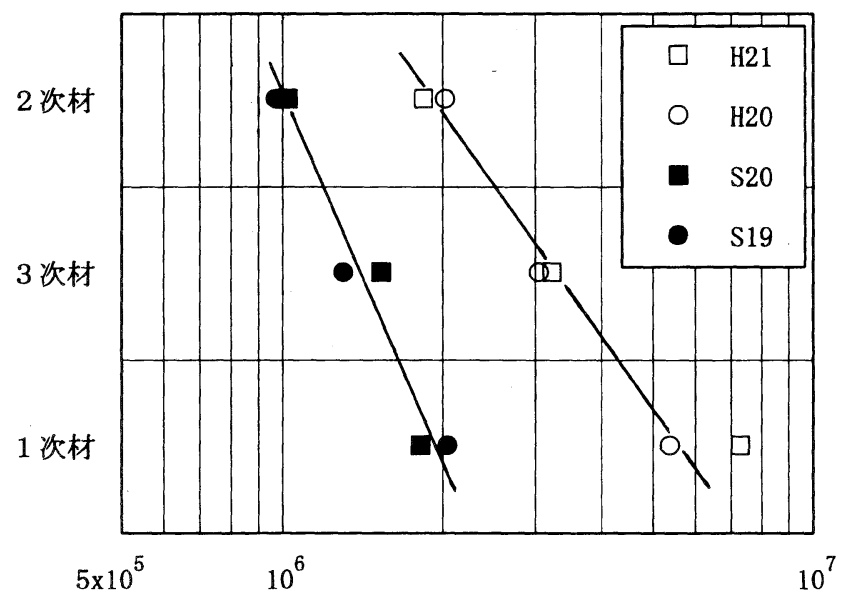

疲労寿命（回）

図 $38 \tau=600 \pm 525,700 \mathrm{MPa}$ 累積ハザード法 $50 \%$ 破壊確率のばねの疲労寿命 (星型疲労試験機)

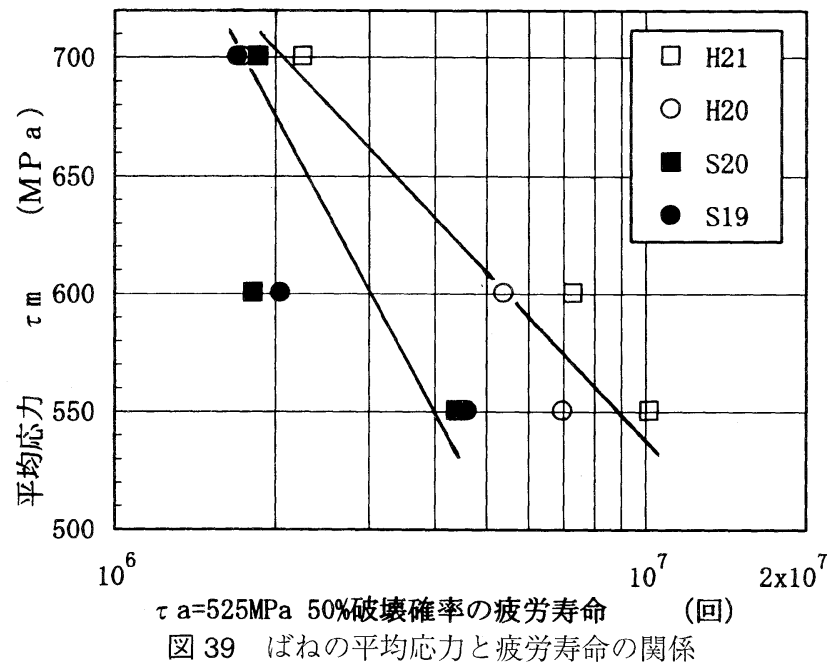

( 1 次材, 星型疲労試験機)

均応力を上げても疲労寿命の低下が小さいのは，ばねのへ たりが増加して，実働の平均応力が上がっていないことも 影響していると思われる。図41 のばね疲労試験での未折損 品の大きな残留せん断ひずみがそれを示している。これを 除けば，当然のことながら，平均応力を下げれば度労寿命 が向上し，平均応力を上げれば疲労寿命は低下するものと 思われる。

\subsection{5 平均応力と応力振幅の関係}

図 43 に，累積ハザード法50\%破壞確率による $10^{7}$ 回のば 数耐久限度線図を，また表 24 に数值デー夕を示す。図中 の直線の傾きは $\tau_{a} / \tau_{m}=1 / 5$ であり, 高強度鋼, 比較鋼とも にほぼこの線上にあり，高強度鋼の方が長寿命である。

\subsection{6 表層部物性値と疲労寿命の関係}

個々の表層部物性値 (硬さ，表面粗さ，残留応力等) と疲 労寿命の関係について調べたが，その関係の明快な説明は現 時点では困難であった。これは，表層部物性値が測定精度上 ばらつきが大きいこと，詳細な金属組織学的観点からの検討 が不十分であったことによるもので，分析精度の向上と詳細 な金属組織学的検討が今後の課題として残された。

\subsection{7 破面観察結果}

注 1 図中の值は同一応力振幅での平均值

注 2 残留せん断ひずみは修正係数を含む

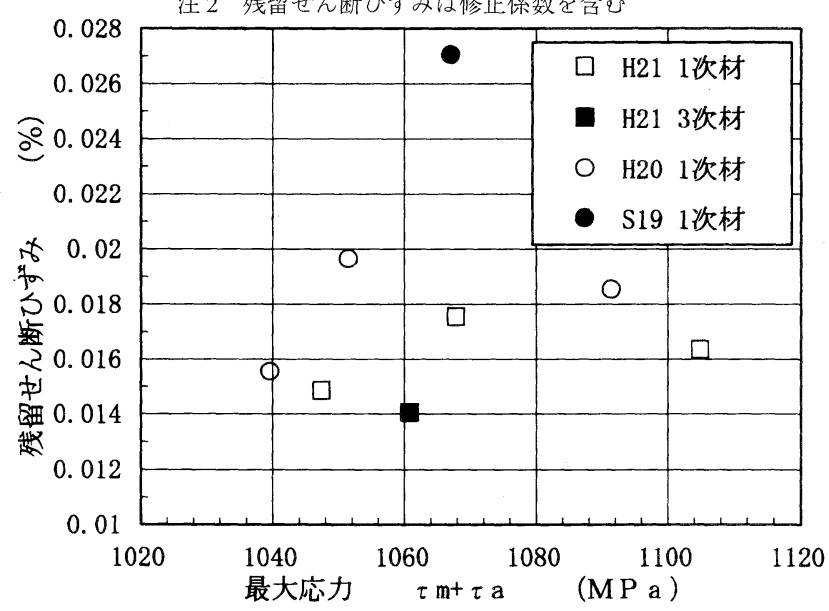

図 40 未折損ばねの残留せん断ひずみ $\left(\tau_{m}=600 \mathrm{MPa}\right)$

注 1 図中の值は同一応力振幅での平均值

注 2 残留せん断ひずみは修正係数を含む

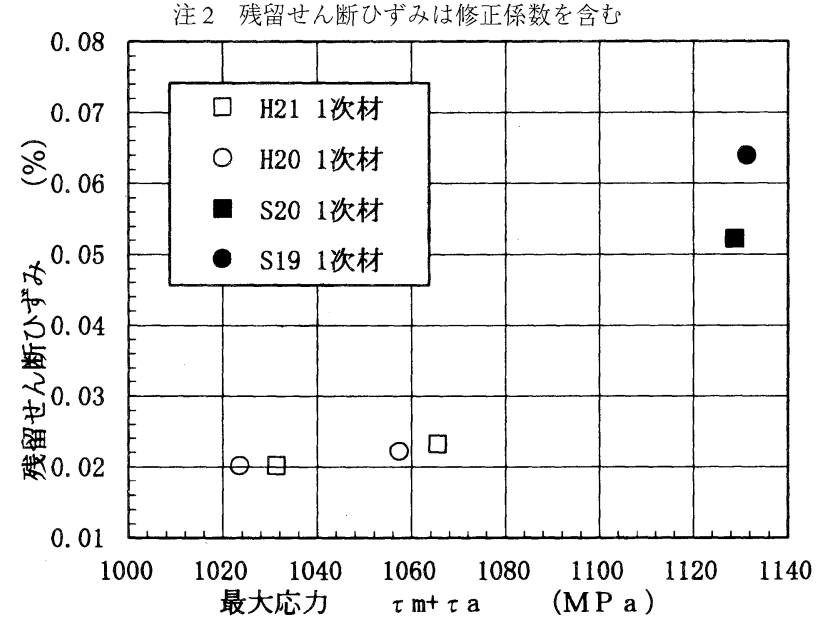

図 41 未折損ばねの残留せん断ひずみ追加試験 $\left(\tau_{m}=550,700 \mathrm{MPa}\right)$ 結果

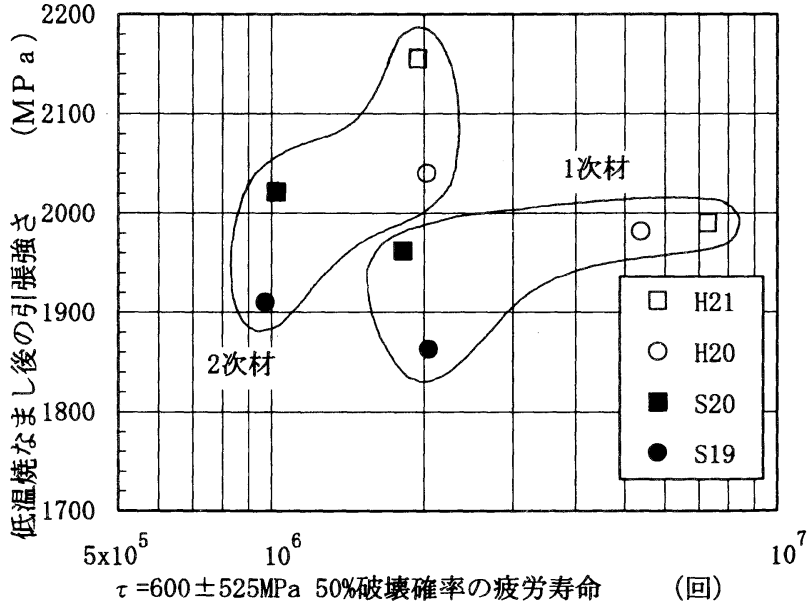

図 42 引張強さと疲労寿命の関係

図 44〜46 に代表的な破面を示す。図 44 は，コイル内側 の表面を起点としたもので過半数がこの種類であった。

図 47 にこの疲労亀裂の進展方向を模式的に示すが，疲労 亀裂は最大せん断応力方向の初期亀裂加主応力方向へ進展 し，最終的には再び最大せん断応力方向へ進展している。供 試ばね諸元に基づいて，巻数に対するばね内外の応力分布を 
はり要素による有限要素法で解析した例を 図48 に示す。 ばね内側のせん断応力が最も大きな値を示しており，実測の ばね折損位置, 龟裂の進展方向（最大せん断応力方向）上良 く一致していた。

その他, 図45 は, コイル内側の内部の非金属介在物を起 点としたものであり, 試験した 912 個中 5 個 (M21が 3 個, $\mathrm{M} 20$ ，S19が各 1 個）見つかった。図46 はコイル内側の内部 ファセットを起点としたもので, 比較的応力振幅の小さな 場合に見られた。一部のフレッチィング摩耗を起点とする 折損品を除くと, 『鋼種, 強度レベル, 処理』が異なっても 生じた破面の種類に違いはなかった。

\section{7 ばねの締付け試験結果とへたり要因の定量評価}

今回の実験で得られたコイルばね素線の残留せん断ひず みと締付け時間の関係を末尾の付図 15 23に示す。これ らのデータを用いて、引張強さ、低温焼なまし温度, ショ

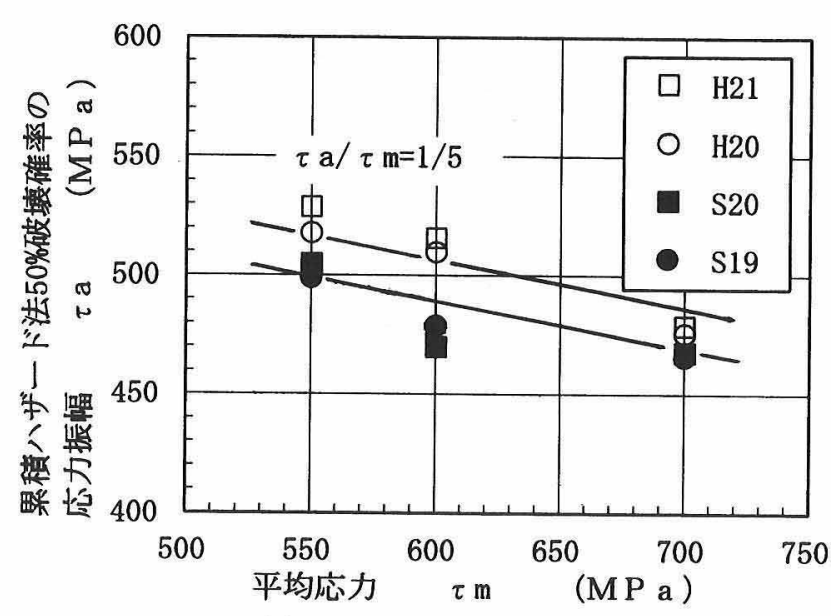

図 431 次材の累積ハザード法50\%破壞確率 による $10^{7}$ 回のばね耐久限度線図

表 24 累積ハザード法 $50 \%$ 破壊確率の場合の $10^{7}$ 回の応力振幅 $\tau_{a}(\mathrm{MPa})$

\begin{tabular}{|c|c|c|c|c|c|}
\hline 金種 & 強度レブル(MPa) & 䞘 理 & $\tau \mathrm{E}=550 \mathrm{MPa}$ & $\tau=600 \mathrm{MPa}$ & $\tau==700 \mathrm{MPa}$ \\
\hline \multirow[t]{2}{*}{ 高強度籍 } & 2100 (H21) & 1次材 & 528 & 515 & 478 \\
\hline & 2000 (H20) & 1㰠材 & 517 & 509 & 475 \\
\hline \multirow[t]{2}{*}{ 比鈎 } & $2000(\$ 20)$ & 1次材 & 504 & 469 & 467 \\
\hline & $1900(\mathrm{~S} 19)$ & 1次材 & 498 & 478 & 465 \\
\hline
\end{tabular}
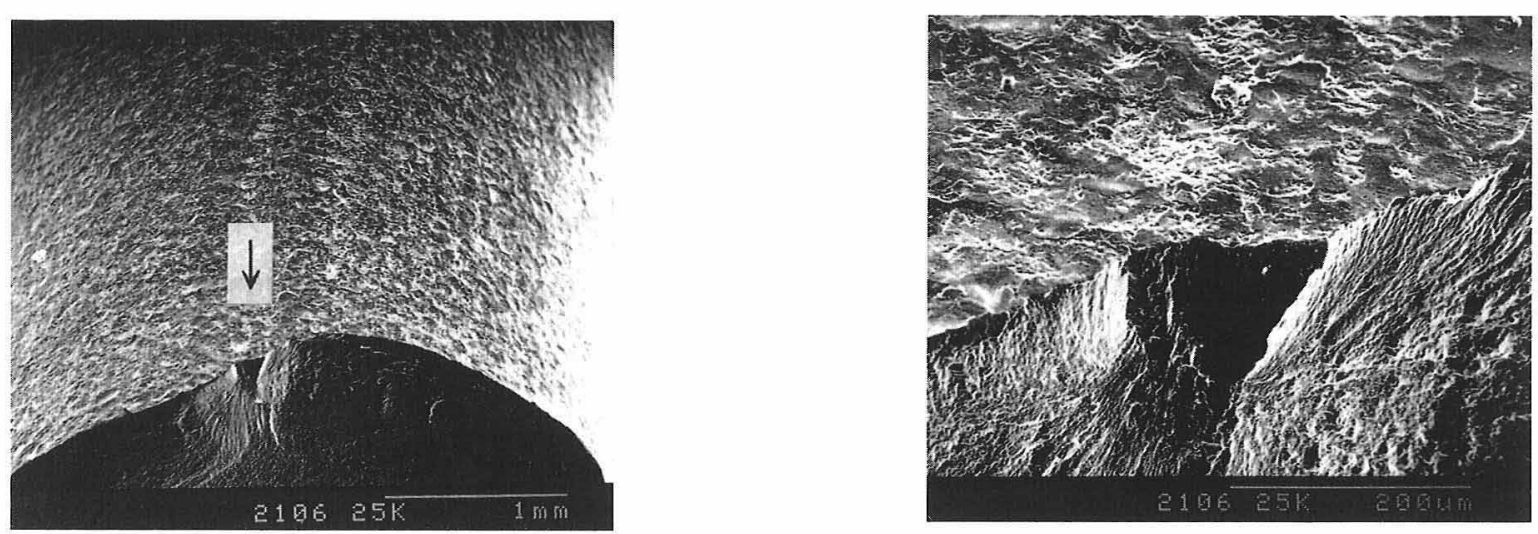

図 44 破面例 I（H21 1 次材 $600 \pm 516 \mathrm{MPa}, 19.81 \times 10^{6}$ 回折損品）
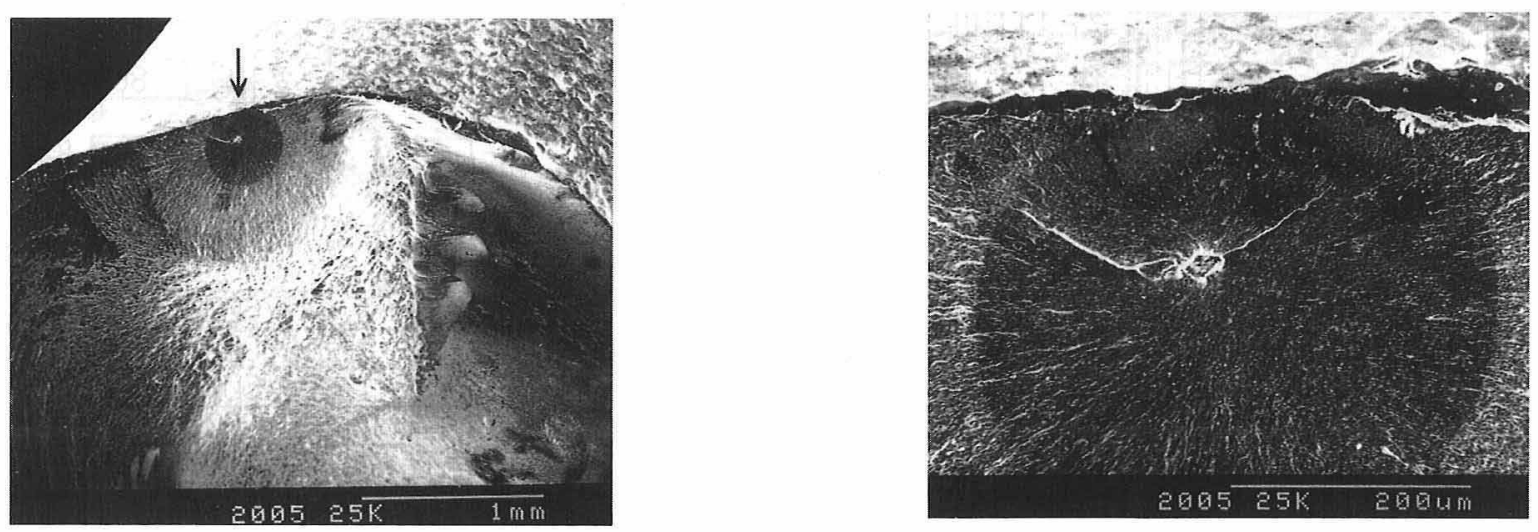

図 45 破面例 II（H20 1 次材 $600 \pm 508 \mathrm{MPa} ， 34.69 \times 10^{6}$ 回折損品） 


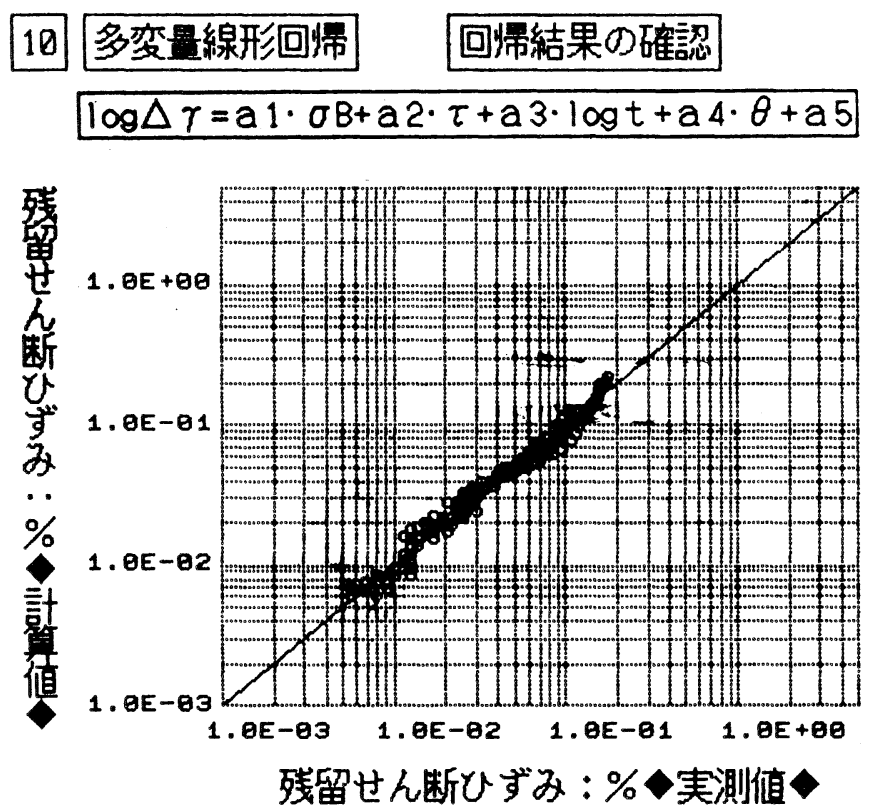

$$
\begin{aligned}
& \text { ファイルタタ HR2FIRST.SCD } \\
& \text { 総デー夕数 } 192 \\
& \text { 有效デー夕 } 192 \\
& 0.000 \leq \Delta \gamma \leq \overline{0.178 \%} \% \\
& 1981 \leqq \sigma \mathrm{B} \leq 1989 \mathrm{MPa} \\
& 447 \leq \tau \leq 890 \mathrm{MPa} \\
& 3 \leqq t \leqq 1000 \text { 時 } \\
& 100 \leqq \theta \leqq 200{ }^{\circ} \mathrm{C} \\
& \text { a } 1-8.88813000 \mathrm{E}-03 \\
& \text { a2 } 2.093060000 \mathrm{E}-03 \\
& \text { a } 3 \text { 9.96814000E-02 } \\
& \text { a } 3.584100000-03 \\
& \text { a5 } 1.409430060+011
\end{aligned}
$$

\section{(a) 高強度龬}

10 多变量線形回帰 回帰結果の確認

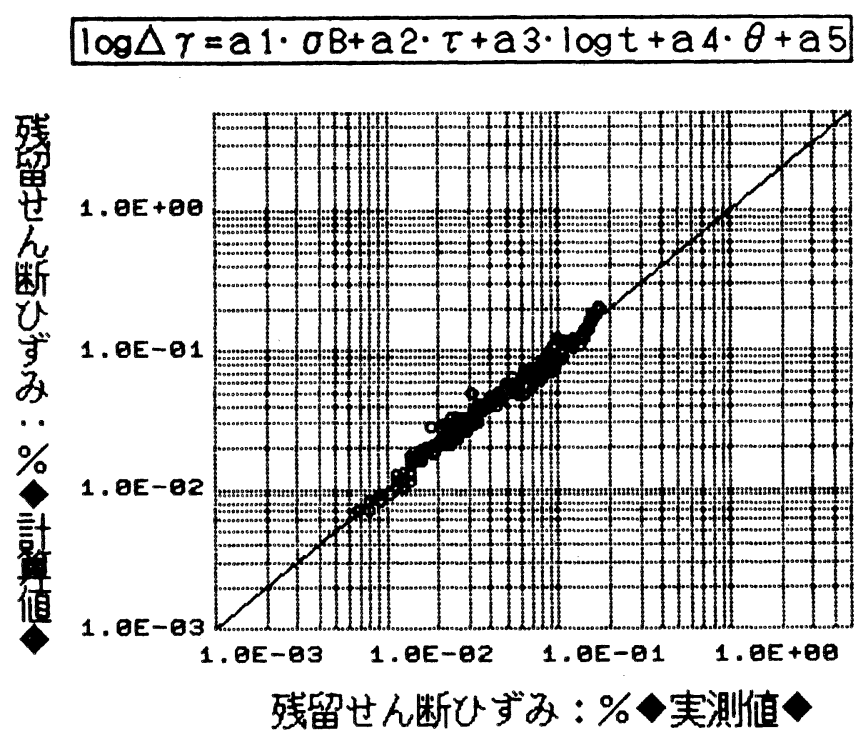

(b) 比較銅

$$
\begin{aligned}
& \text { ファイルタ名 H21FIRST.SCD } \\
& \text { 総データ数 } 192 \\
& \text { 有效データ } 192 \\
& 0.007 \leq \Delta r \leq 0.175 \% \\
& 1867 \leq \sigma \mathrm{B} \leq 198 \mathrm{MPa} \\
& 438 \leq \tau \leq 869 \mathrm{MPa} \\
& 3 \leq t \leq 1000 \text { 時 } \\
& 100 \leq \theta \leq 200{ }^{\circ} \mathrm{C}
\end{aligned}
$$

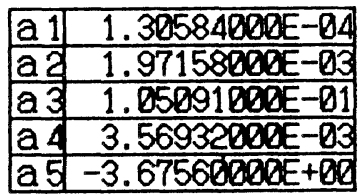


10 多变量線形回慢 回帰結果の確認

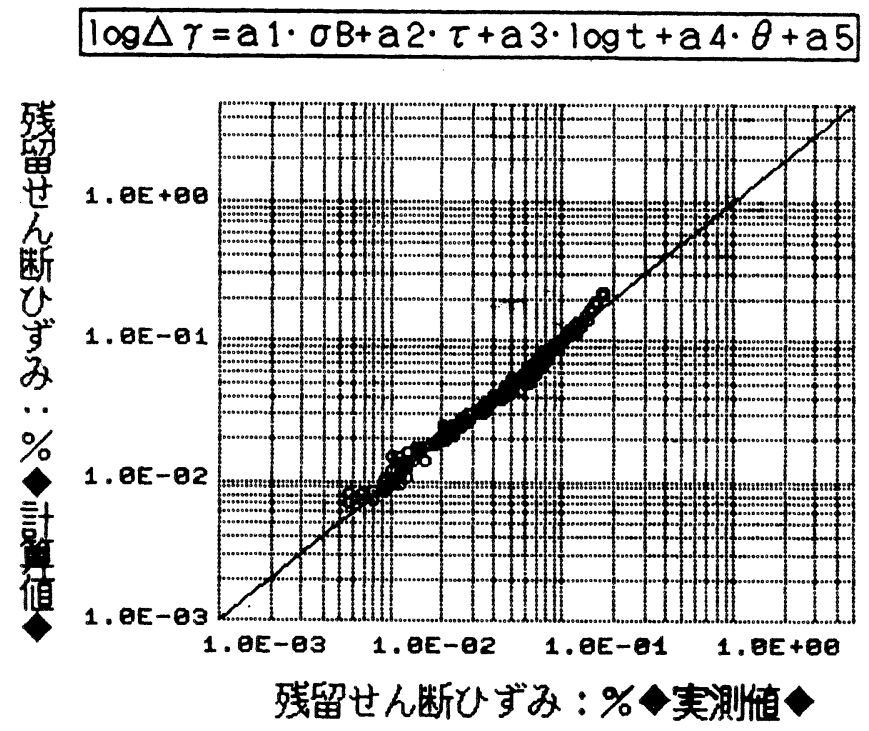

(a) 高強度筒

\begin{tabular}{|c|c|}
\hline ファイル名 & H22SECON. SCD \\
\hline 倊データ数 & 192 \\
\hline 有効データ & 192 \\
\hline $.000 \triangle \triangle \gamma$ & $\leq 0.178 \%$ \\
\hline$\sigma \mathrm{B}$ & \\
\hline$\overline{414} \leq \tau$ & $826 \mathrm{MPa}$ \\
\hline $3 \leq t$ & $\leqq 1000$ 時 \\
\hline $100 \leq \theta$ & $200{ }^{\circ} \mathrm{C}$ \\
\hline \begin{tabular}{|l|c|}
$\mathrm{a} 1$ & 5.4342 \\
$\mathrm{a} 2$ & 1.8227 \\
$\mathrm{a} 3$ & 1.1040 \\
$\mathrm{a} 4$ & 4.5880 \\
$\mathrm{a} 5$ & -3.5278 \\
\end{tabular} & $\frac{10000 \mathrm{E}-05}{\frac{0000 \mathrm{E}-03}{1000 \mathrm{E}-01}}$ \\
\hline
\end{tabular}

ファイル名 HR1SECON.SCD 総デー夕数 192 有効データ 192 $0.007 \leq \Delta \gamma \leq 0.188 \%$ $1909 \leq \sigma \mathrm{B} \leq 2020 \mathrm{Ma}$ $420 \leq \tau \leq 830 \mathrm{Ma}$ $3 \leq t \leq 1000$ 時 $100 \leq \theta \leq 200{ }^{\circ} \mathrm{C}$ \begin{tabular}{|l|r|}
\hline $\mathrm{a} 1$ & $2.56596000 \mathrm{E}-0 \mathrm{5}$ \\
\hline $\mathrm{a} 2$ & $1.81961000 \mathrm{E}-03$ \\
\hline $\mathrm{a} 3$ & $1.04243000 \mathrm{E}-01$ \\
\hline $\mathrm{a} 4$ & $4.31386000 \mathrm{E}-03$ \\
\hline $\mathrm{a} 5$ & $-3.40268000 \mathrm{E}+00$ \\
\hline
\end{tabular} 残留せん断ひずみ：\%॰実測値 (b) 比較銅

図 512 次材のBANEXによる多変量線形回帰結果 


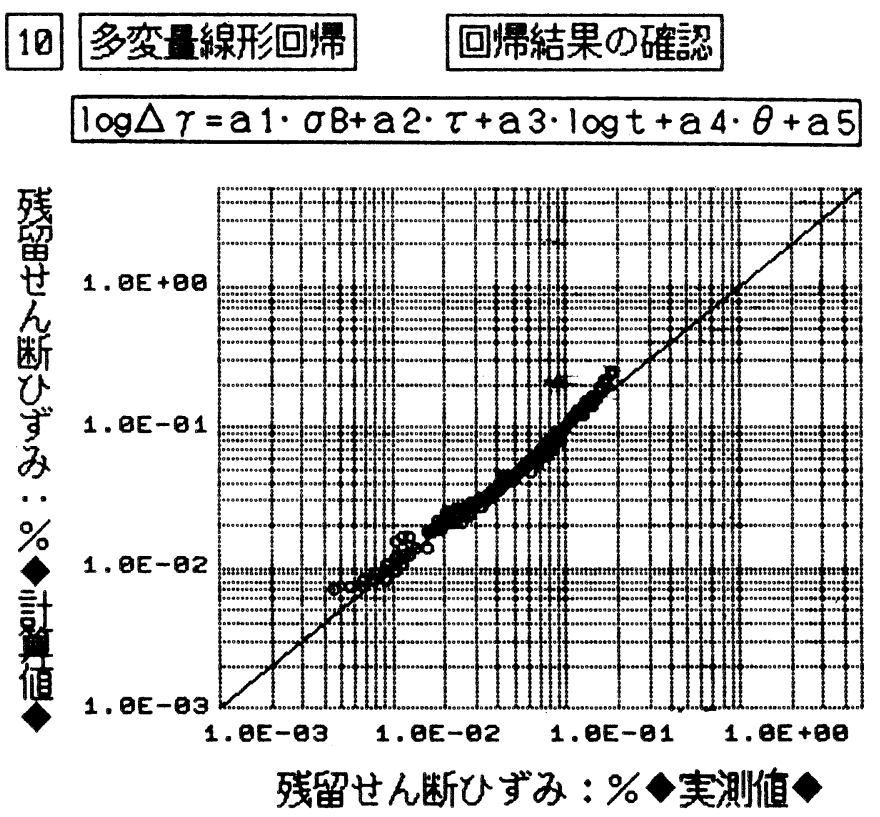

(a) 高強度銅

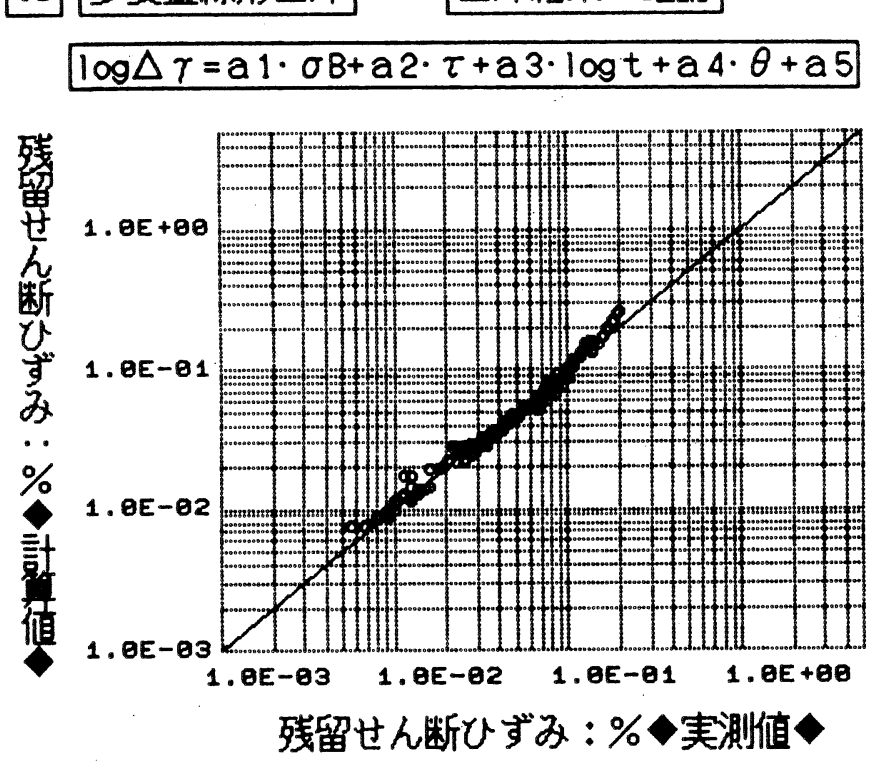

$$
\begin{aligned}
& \text { ファイル名 HE1THIRD.SCD } \\
& \text { 総データ数 } 192 \\
& \text { 有效データ } 192 \\
& 0.006 \leq \Delta r \leq 0.199 \% \\
& 1969 \leq \sigma \mathrm{B} \leq 2022 \mathrm{PPa} \\
& 423 \leq \tau \leq 848 \mathrm{MPa} \\
& 3 \leq t \leq 1000 \text { 時 } \\
& 100 \leq \theta \leq 2800^{\circ} \mathrm{C} \\
& \begin{array}{|l|r|}
\hline \mathrm{a} 1 & 7.31811000 \mathrm{E}-0 \mathrm{a} \\
\hline \mathrm{a} 2 & 1.89060000 \mathrm{E}-03 \\
\hline \mathrm{a} 3 & 1.08688000 \mathrm{~B}-01 \\
\hline \mathrm{a} 4 & 4.61824000 \mathrm{D}-03 \\
\hline \mathrm{a} 5 & -3.57989000 \mathrm{D}+00 \\
\hline
\end{array}
\end{aligned}
$$

（b）比較鋼

図 52 3 次材のBANEXによる多变量線形回帰結果 


\section{0 多変量線形回帰 回帰式による推定} $\log \triangle \gamma$ と $\sigma \mathrm{B}$ O関係
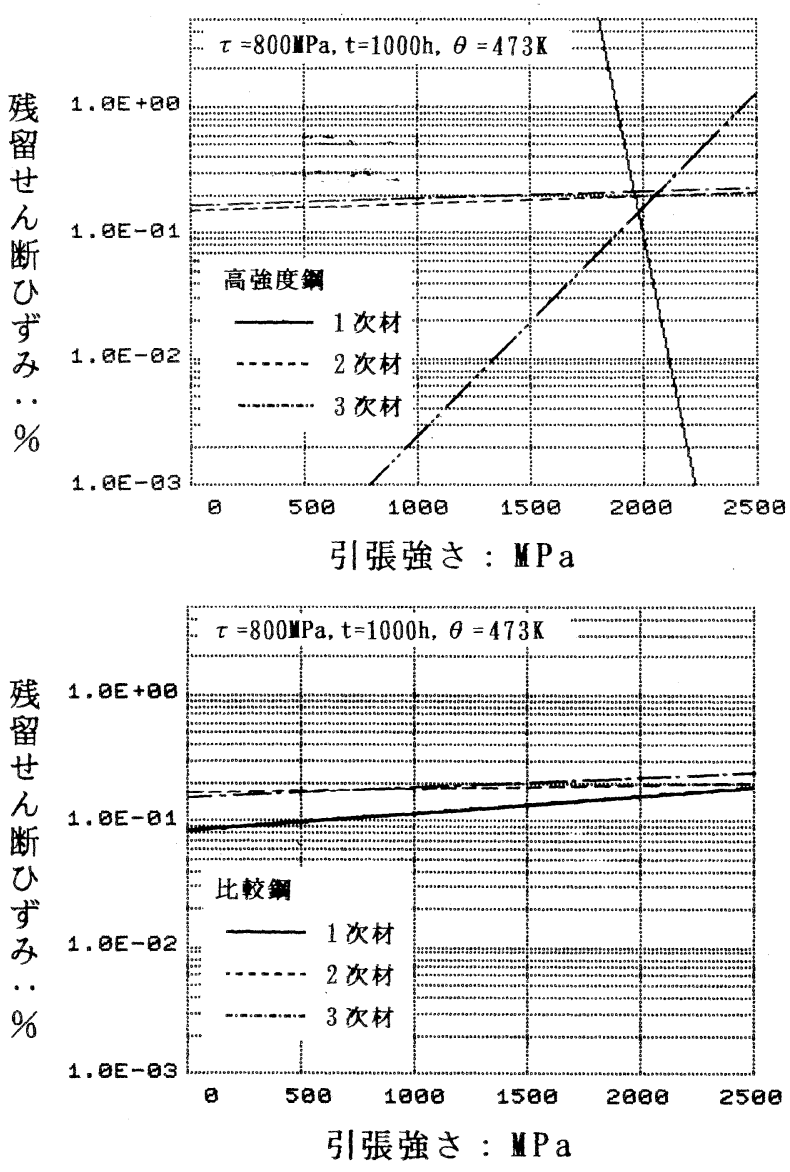

図 53 へたりに及ほす引張強さの影響 (上図中の 2 点鎖線は，1次材の $\mathrm{H} 200$ )引張強さを $\mathrm{n}=3$ の平均 $1981 \mathrm{MPa} ら \mathrm{n}=2$ の平均 $1966 \mathrm{MPa}$ 一修正したものを示す。)

ットピーニング，締付け応力，締付け時間，締付け温度の 各因子が残留せん断ひずみに及活す影響を定量評価するた めにBANEX $\left.{ }^{100}, 11\right)$ にる多変量線形回帰老行い，回帰式に よる残留せん断ひずみの推定を行った。

まず，室温(293K)，373K，473Kの全データで整理した 例を図 49 に示すが，室温でのデータが373K，473Kの データと比べて大きくばらつくため，回帰は明らかに悪い (付図15〜23 参照)。このばらつきの原因は，セッチング後 に熱処理を行っていないため，セッチングによって生じた 可動転位が固着されないためではないかと考えられる。ま た，弁ばねの実用面から室温でのへたりはほとんど問題に されないので, 室温での試験結果を除外し，373Kと $473 \mathrm{~K}$ のデータのみを用いて整理した。図50～図52に，高強度 鋼と比較鋼について 1 次材から 3 次材までを各々個別に回 帰した結果を示す。各々，有効データが192個ずつあるが， 図49にくらべてばらつきが少なく，良い回帰を示している。 図53 はへたりに及ほする張強さの影響を示して抢り，高強 度鋼の 1 次材を除くと,引張強さとともにへたりは増加す る傾向にあることがわかる。な拉，高強度鋼の1次材は
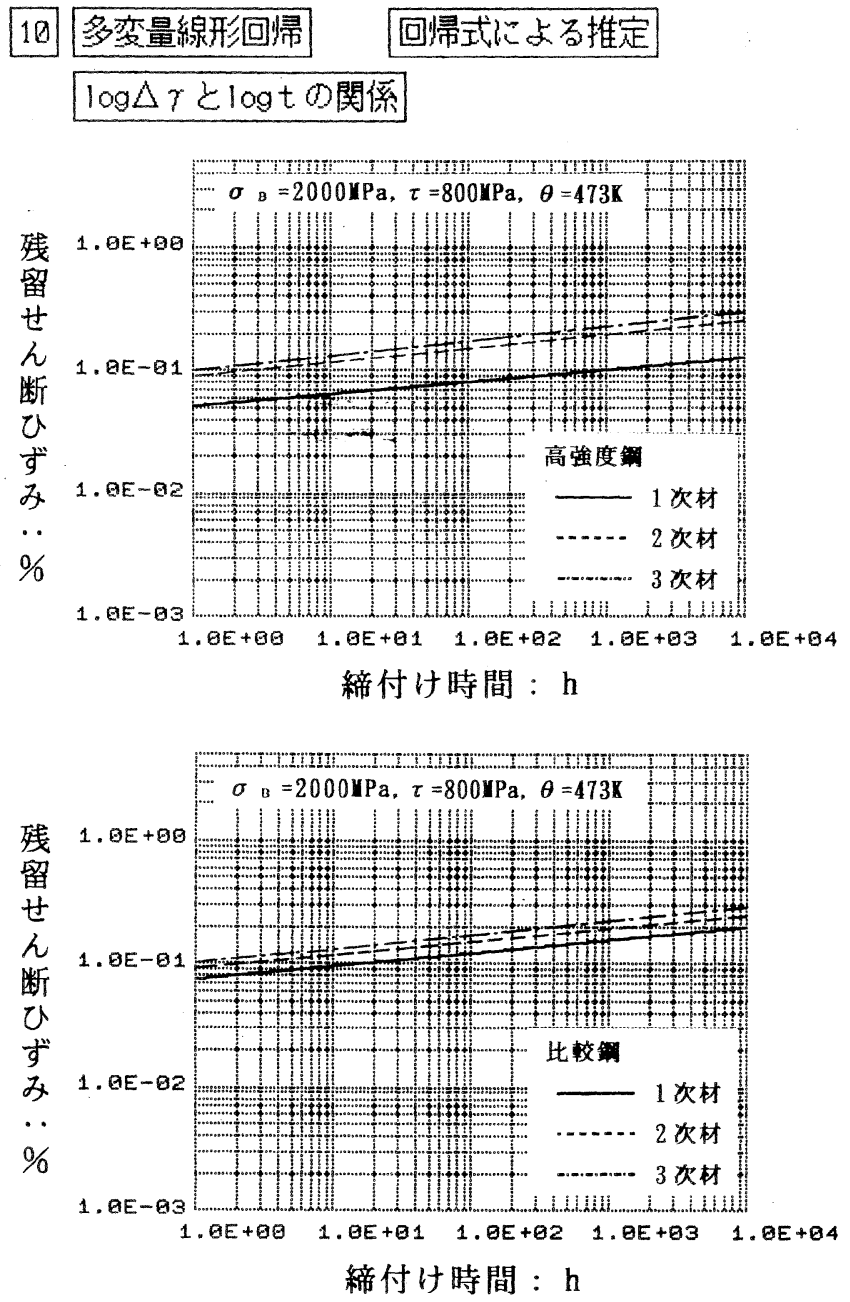

図 54 へたりに及ぼす低温焼なまし， ショットピーニングの影響

$\mathrm{H} 20$ の引張強さのデータがばらついていることと, H21 と $\mathrm{H} 20$ の強度差がほとんどないことから，他の鋼種と逆傾向 を示したものと思われる。参考までに，図中に 2 点鎖線で 1 次材の $\mathrm{H} 20$ の引張強さをデー夕数 $\mathrm{n}=3$ の平均值 $1981 \mathrm{MPa}$ から $\mathrm{n}=2$ の平均值 $1966 \mathrm{MPa}$ 一修正した例を示すが, 修正 後は傾きが正となり，引張強さのデータのばらつきの影響 が大きいことがわかる。

図54はばねのへたりに及ぼす低温焼なまし，ショット ピーニングの影響を示す。低温焼なまし温度の高い 1 次材 では高強度鋼の方がへたりは小さい傾向があるが，低温焼 なまし温度の低い 2 次材, ダブルショットピーニングを施 した 3 次材は 1 次材よりへたりが大きくなり, 高強度鋼と 比較鋼の差は少なくなる。

図55はへたりに及ぼす締付け温度の影響を示す。一般的 に締付汁温度が高くなるほどへたりやすくなる。また，1 次材のほうが 2 次材， 3 次材に比べてへたりにくい傾向が ある。

図56はへたりに及ぼす締付け応力の影響を示す。締付け 応力の増加に伴ってへたりは増加する傾向があり，これま 
10 多变量線形回帰 回帰式以よる推定 $\log \Delta r$ と $\theta$ の関係
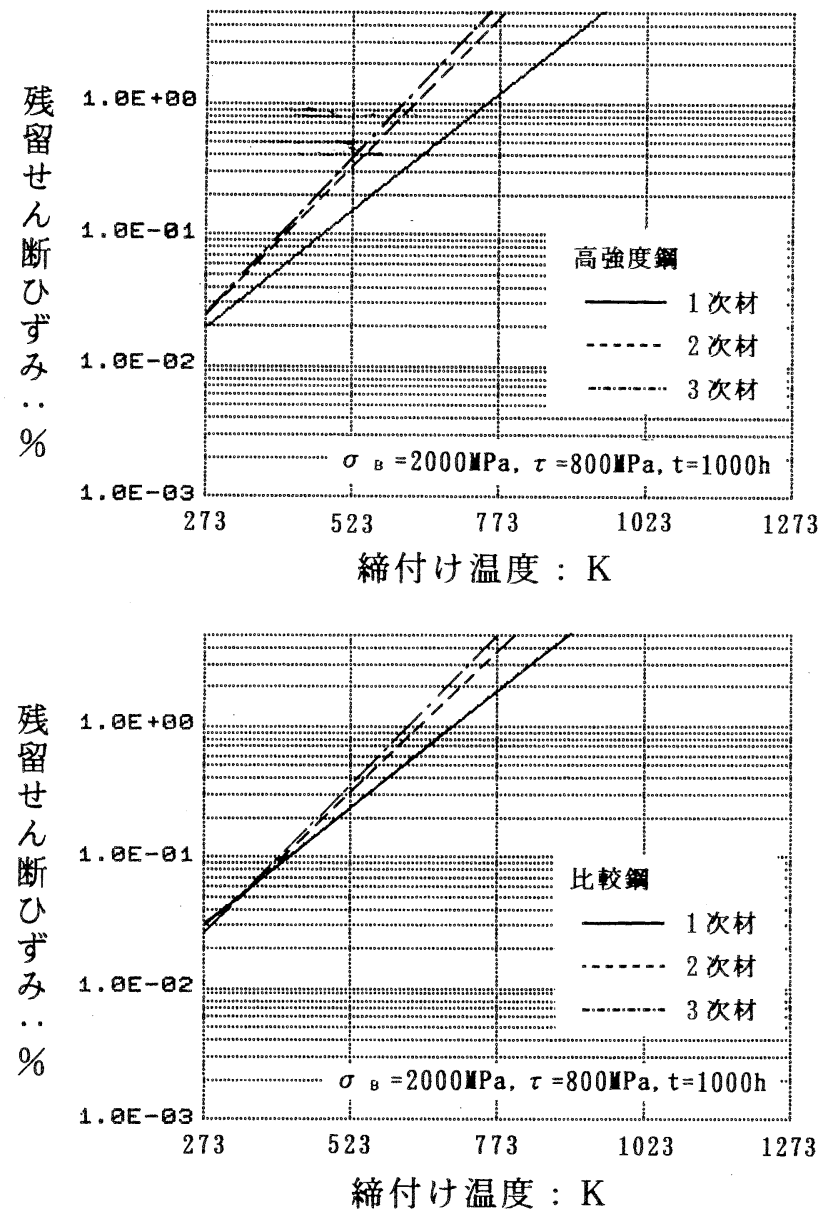

図 55 へたりに及ぼす締付け温度の影響
10 多変量線形回帰 回帰式以よる推定 $\log \Delta \gamma$ 乙 $\tau$ の関係
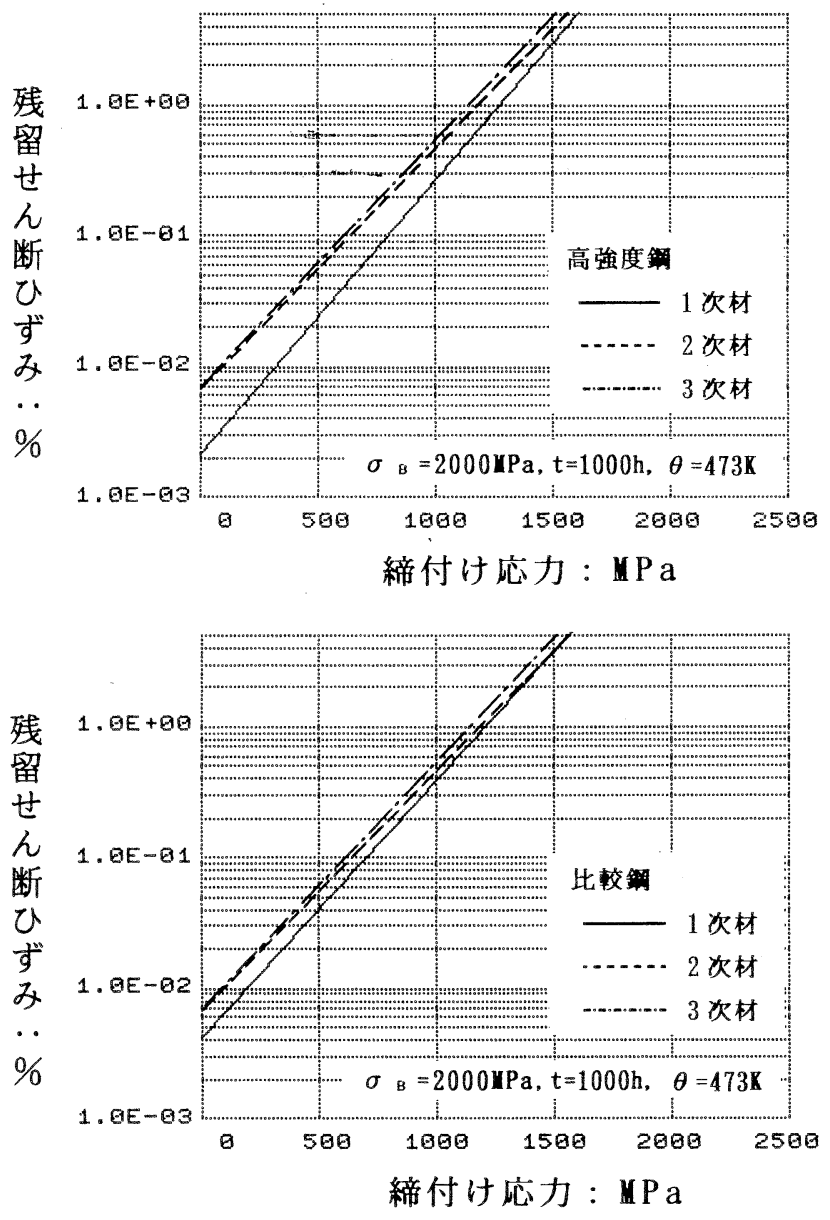

図 56 へたりに及ほす締付け応力の影響
10 多変量線形回帰回帰結果の確認

$\log \Delta \gamma=\mathrm{a} 1 \cdot \sigma \mathrm{B}+\mathrm{a} 2 \cdot \tau+\mathrm{a} 3 \cdot \log t+\mathrm{a} 4 \cdot \theta+\mathrm{a} 5$

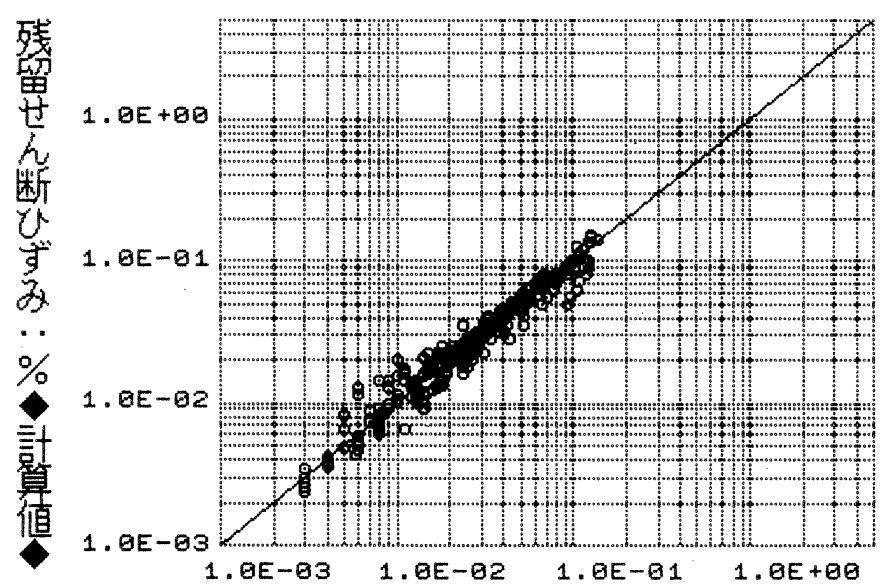

殘留せん断ひずみ：\% 実測値
ファイル名 MNN100.SCD

総データ数 268

有効データ 232

$0.003 \leqq \triangle \gamma \leqq 0.137 \%$

$1855 \leqq \sigma \mathrm{B} \leqq 1908 \mathrm{MPa}$

$378 \leqq \tau \leqq 800 \mathrm{MPa}$

$3 \leqq t \leqq 3000$ 時

$100 \leqq 8 \leqq 200{ }^{\circ} \mathrm{C}$

\begin{tabular}{|l|r|}
\hline a 1 & $4.26683000 \mathrm{E}-03$ \\
\hline a & $2.50651000 \mathrm{E}-03$ \\
\hline $\mathrm{a} 3$ & $1.0236200 \mathrm{~B}-01$ \\
\hline a 4 & $2.98255000 \mathrm{E}-03$ \\
\hline $\mathrm{a} 5$ & $-1.18816000 \mathrm{~B}+01$ \\
\hline
\end{tabular}

図 57 従来のBANEXデー夕（SWOSC-V，線径4mm, SP未処理材）の多变量線形回帰結果 
10 多変量線形回埽 回㷌式による推定

\section{$\log \Delta r$ とlogt の関係}

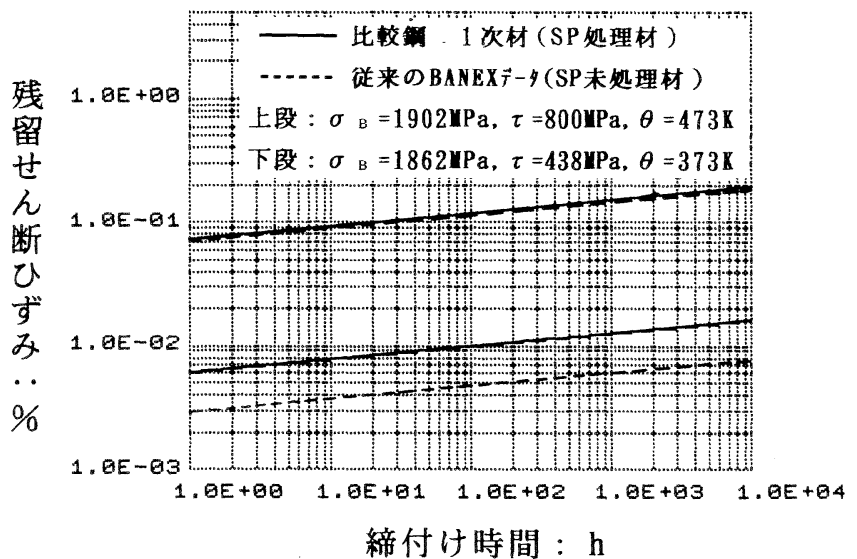

図 58 従来のBANEXデー夕と本研究デー夕との回帰結果の比 較例

での結果と同様に, 1 次材では高強度鋼の方がへたりは小 さく, 2 次材， 3 次材になると差はほとんどなくなる。

従来のBANEXのへたりデー夕をみると，SWOSC 製コ イルば叔のワールの修正係数を含まないものでショット ピーニング処理材に関するデー夕は僅かに20個しかなく， 今回の委員会で得られたショットピーニング処理材のへた りに関するデータは非常に貴重なことがわかった。そこで， 図 57 に従来のBANEXのへたりデータから検索したショッ トピーニング未処理材のデータ(268個)を示す。また，こ のデータと今回の測定結果との比較を 図 58 に示す。図中, 上段は最もへたりの大きな，また，下段は最もへたりの小 さな両者共通の条件で比較したものである。これより, 締 付け時間に対するへたりの増加の勾配は両者で良く似てい ること，最もへたりの小さな条件ではショットピーニング を行った今回のデータの方がへたりやすいこと，さらには， へたりが大きい条件では両者の差はほとんどなくなること などがわかった。

\section{5. まとめ}

以上, 高強度鋼線の耐久性に関する調查研究委員会弁ば 亦用ワーキンググループでは, 鋼種, 強度, 低温焼なまし 温度, ショットピーニングなどが線の機械的性質, 表面性 状, 疲労特性, 切欠き感受性, 加工性などに及活す影響及 び，圧縮コイルばねの疲労，へたり特性などに及ほすす影響 について調査・研究を行い，ばねの高強度化に当たっての 問題点を明らかにした。以下, 本ワーキンググループで得 られた成果をまとめて示す。

\section{1 材料特性}

（1）素線の基本的な性質

(1)高強度鋼と比較鋼では結晶粒が大きく異なり, 高強度 鋼が粒度 NO.12.6 に対し, 比較鋼が 8.7 と粗粒であった。

(2)介在物レベルは高強度鋼の方がやや悪い（介在物評価 点で2）傾向を示した。
(3)オイルテンパー線そのものの残留オーステナイトは 数\%と少なく，鋼種，強度の差は見られなかった。また， 598K 低温焼なましでは残留オーステナイトはほとんど分解 していた。

(2) 機械的性質

(1)引張強さ，ねじり強さはともに $673 \mathrm{~K} \times 25 \mathrm{~min}$ の低温焼 なましまではオイルテンパーのままの強度レベルと同等か それ以上の值を示すが，この温度以上の低温焼なましでは 急激に低下した。

(2)引張強さ，ねじり強さが最も応力が大きくなるのは $598 \mathrm{~K} \times 25 \mathrm{~min}$ の低温焼なましの場合であった。なお，この 傾向は高強度鋼，比較鋼ともに同じであった。

\section{2 加工性}

(1)今回のコイリング条件 $(2$ 本ピン,$D / d=5.7)$ に执い ては高強度鋼 OT線, 比較鋼 OT線ともに折損はなく, コイ ル形状のばらつきも両鋼種で同程度であった。

(2)線のノッチ曲げ試験においては高強度鋼の方が切欠き 感受性が大きいことが判明した。また，さらに高強度化し たり，加工度が大きくなると折損等が問題になるかも知れ ないが，現行の并ばね仕様では問題はなさそうである。

\section{3 加工ひずみの除去}

(1)一般的には高強度鋼 OT線の方が比較鋼 OT線より加 工後，コイル内径側の引張残留応力が大きいと思わるが, 今回の結果では高強度鋼と比較鋼とで差は見られなかった。

(2)低温焼なまし温度の上昇とともに, 引張残留応力は減 少した。しかし, 引張強さレベルを保つために通常, 低温 焼なまし温度は上限として $698 \mathrm{~K} \times 25 \mathrm{~min}$ 程度が選定されて いる。

\section{4 線の耐久性}

試験に先立ち, 中村式回転曲げ疲労試験機の機差が問題 となり，機差を検定した結果，107回耐久限には担当メ一 カーによって最大 $73 \mathrm{MPa}$ の差が認められた。このため, 本 研究では使用するブッシュを統一し，応力の設定方法も統 一した上で， 1 社で 4 鋼種全部を，他の 3 社で 2 鋼種の疲 労試験を行ってこれを補う方法を取った。

(1)得られた $10^{7}$ 回耐久限は, 低温焼なまし温度が低いほど, また，素線強度が高いほど向上した。

(2)シングルショットピーニングよりダブルショットピー ニングの方が耐久性が向上し, 1 次材 $<2$ 次材 $<3$ 次材の順 に耐久限が増大した。

(3) 3 次材の $10^{7}$ 回耐久限は $1000 \mathrm{MPa}$ 老超兄, 従来の疲労 強度レベルを大きく上回った。

(4)鋼種及び強度により $\mathrm{S} 20>\mathrm{H} 21>\mathrm{S} 19>\mathrm{H} 20$ の順に耐久 性は低下した。

なお，今後の課題として機差の原因を明らかにし，対策 を施して試験方法の標準化を図る必要がある。

\section{5 ばねの耐久性}

ばねの疲労試験には 4 社で星型疲労試験機，1社で油圧 サーボ型疲労試験機を用いたが, 得られた $\mathrm{SN}$ 線図に大きな 差はなく，また，星型疲労試駼機の機差もほとんどなかった。 
疲労試験の結果,

(1)化学成分の影響は明白で, 比較鋼に比べて高強度鋼は $\tau_{m}$ $\pm \tau_{\mathrm{a}}=600 \pm 500 \mathrm{MPa}$ の条件下で疲労寿命が約 2 倍となった。

(2)しかし，強度の影響はほとんどなく，いずれの熱処理， ショットピーニング条件でも寿命レベルは $\mathrm{S} 19=\mathrm{S} 20<$ $\mathrm{H} 20=\mathrm{H} 21$ となった。

(3)時間強度でみると低温焼なまし温度の低い, 素線強度 の高い 2 次材の方が低温焼なまし温度の高い, 素線強度の 低い 1 次材より低寿命となった。

(4)シングルショットピーニング材 (2 次材) よりダブルシ ヨットピーニング材 (3 次材) の方が長寿命となった。ただ し,この 3 次材は 1 次材よりは寿命が短かった。

\section{6 ばねの耐へたり性}

(1)室温を除く高温のデータは多変数線形回帰により精度 良く回帰できた。

(2)線の引張強さを上げたりコイリング後の低温焼なまし 温度を低下させて高強度化したり，あるいはダブルショッ トピーニングを行うことにより耐へたり性は低下した。

(3)化学成分の影響が若干見られ, ある条件下では高強度 鋼の方が優れた耐へたり性を示した。ただし，低温焼なま し温度を低下させたり，ダブルショットピーニングを施す と高強度鋼と比較鋼の差はほとんどなくなった。

\section{7 総合評価}

高強度化にあたって弁ばね用線に要求される主な特性と しては, 加工性の維持, 耐久性, 耐へたり性の 3 点が挙げ られるが, 今回調査・研究した高強度鋼は従来の JIS 規格 の標準鋼に比べて, 加工性は同等, 耐久性は大幅に向上, 耐へたり性は同等以上であり，高強度鋼の優位性が判明し た。ただし，高強度鋼でさらに耐久性や耐へたり性を向上 させるには，単なる素線の高強度化よりも，化学成分の変 更や低温焼なまし条件の適正化, さらには従来以上にショ ットピーニングなどの表面処理技術の改善が重要なことが 判明した。

\section{8 今後の課題}

今回の調査・研究過程において, 評価方法そのものも含 めいくつかの問題点が明らかになった。例えば，以下のこ とが今後の検討課題として残された。

(1)中村式回転曲げ疲労試験機の機差の原因。

(2)線の中村式回転曲げ疲労試験とばねの疲労試験の結果 が対応しない原因。従来, 線の中村式回転曲げ疲労試験結 果はばねの疲労強度を相対的に評価するものと考えられて きたが，今回の結果を見る限り，両者の定性的傾向も一致 しなかった。これについては，以下の原因が考えられる。

a. 線の回転曲げ度労試験では耐久限に主眼を置きステア ケース法を採用したため, ばねの累積ハザード法とは評価 法が異なり，かつ，応力振幅の幅の狭いところで評価して いる。

b. ばねの疲労試験では介在物折損がほとんど見られなか ったが，線の回転曲げ疲労試験では介在物折損が多く見ら れた。今回のステアケース法ではとくにこの介在物折損と
通常の表面起点の折損とを区別していない。

c. 応力形態が曲げと据りで異なる。

d. 残留応力は線では軸対称的分布なのに対して, ばねで はセッチングなどにより軸方向, $45^{\circ}$ 方向, $90^{\circ}$ 方向, $135^{\circ}$ 方 向で異なる。

(3)適正な化学成分の検討。単に同一化学成分で耐久性の 向上を図る方法は限界のようであり, 添加元素の変更によ りさらに耐久性を向上させうることがわかった。ただし， 「なぜ，高強度鋼の方が耐久性が向上したのか？」に関して 金属学的な考察（強度〜じん性バランスの改善効果, オー ステナイト結晶粒微細化効果, 炭化物の微細析出効果など） とそれに基づく適正な化学成分の検討が必要である。

(4)適正な低温焼なまし条件, ショットピーニング条件の 検討。今回の結果では, 素線強度よりも低温焼なまし, シ ヨットピーニング条件の適正化がばねの耐久性向上にとっ て重要であることが判明した。ただし，その理由は加工ひ ずみや可動転位により単純には説明できないようであり, 「なぜ，ばねの耐久性で大きな差を生じたのか？」に関する 考察とそれに基づく適正な低温焼なまし条件, ショット ピーニング条件の検討が必要である。

以上, 本ワーキンググループによる研究事項及びその成 果について述べた。これらの成果が今後, 高強度線の実用 化の定着や JIS 規格の改正などの一助となれば幸いである。

なお，末尾に付図，付表として中村式回転曲げ疲労試験 結果, ばね疲労試験結果, へたり試験結果のデータを添付 するが，その他のデータも含め全データは BANEXに登録 される予定であり，詳細はそちらを参照されたい。

追記：これまでの研究結果との比較検討

本研究をもって高強度線の耐久性に関する調査研究は終 了するが, 細物用ワーキンググループ12), 懸架用ワーキン ググループ4)，及び弁ばね用ワーキンググループの主要な研 究結果を比較すると表 25 のようになる。すなわち, 細物 ばねと弁ばねでは線の疲労, ばねの疲労, 耐へたり性など の引張強さ依存性については整合性のある結果が得られて いるが，問題となる点は以下の通りである。

(1)ばねの耐久性

化学成分の影響については，懸架ばねでは高強度鋼と比 較鋼とで差が見られなかったのに対し, 弁ばねでは高強度 鋼の方が優れた耐久性を示した。これは懸架ばねの研究で は鋼種と強度を同時に変えていること, 弁ばねと㲘架ばね ではやや成分が異なること, さらには, ばね形状・寸法, 残留応力分布, 負荷応力形態 (細物ばね, 弁ばねではばね 内径側のせん断応力が最大応力となり，懸架ばねではばね 外側の主応力が最大応力となる）などの差が影響している と思われるが，現時点では原因は明確でない。今後これら の因子を同一の水準で比較検討することが必要である。

(2)耐へたり性

化学成分の影響については, 懸架ばねでは高強度鋼の方 が耐へたり性が優れているのに対し4),13)，弁ばねでは高強 


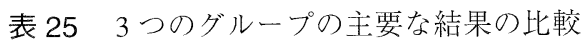

\begin{tabular}{|c|c|c|c|}
\hline グループ & 細物 & 弁ばね & 戀架 \\
\hline 質 & $\begin{array}{l}\text { 高強度鈎SIOSC-V相当 (L, I, H) } \\
\text { ハイカーボン材 } 0.6 C\end{array}$ & 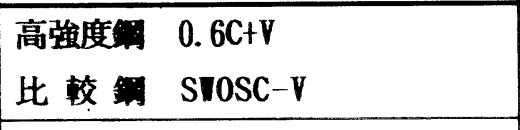 & 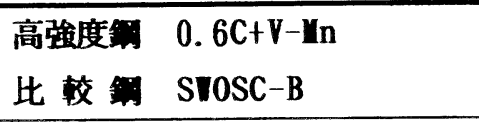 \\
\hline 結晶粒度 & - & 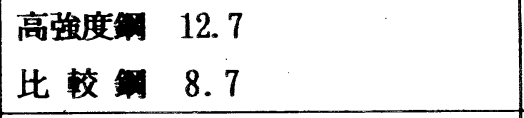 & 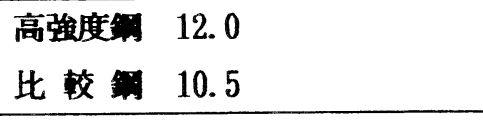 \\
\hline 径 & $0.8 \mathrm{~mm} 、 1.6 \mathrm{~mm}$ & $4.0 \mathrm{~mm}$ & $11.5 \mathrm{~mm}$ \\
\hline 素缐強度 & 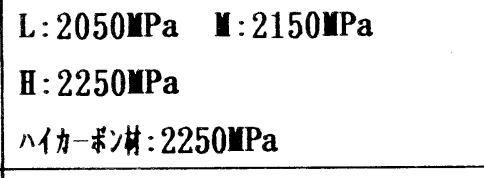 & 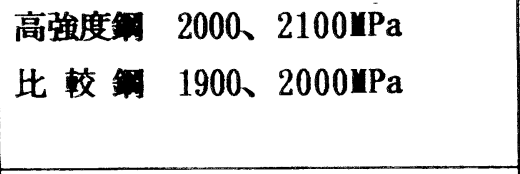 & 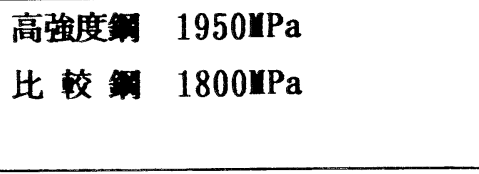 \\
\hline $\begin{array}{l}\text { 線の低湜焼 } \\
\text { なまし特性 }\end{array}$ & 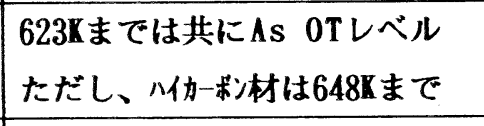 & 673Kまでは共にAs 0Tレベル & 673Xまでは共に $\Lambda$ s 0Tレベル \\
\hline 線の掣労 & 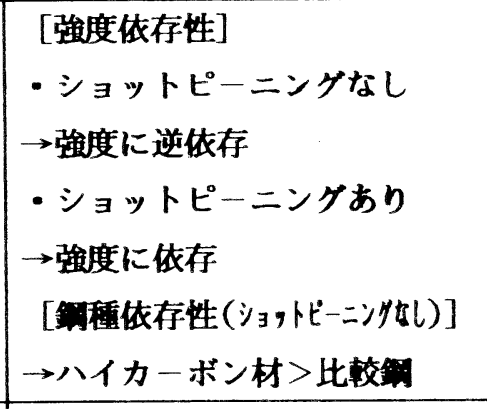 & 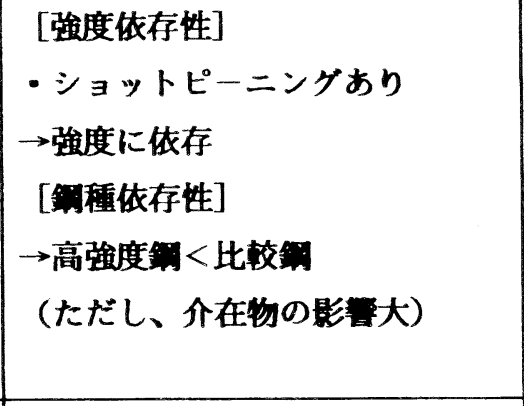 & - \\
\hline ばね度労 & 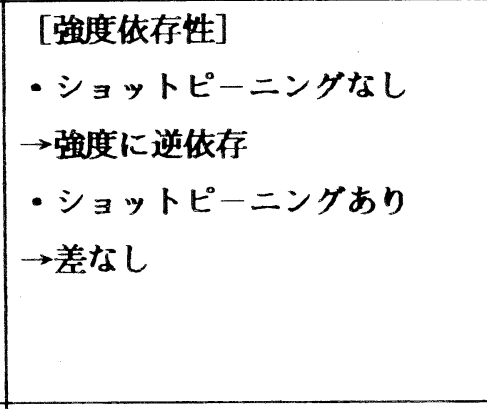 & 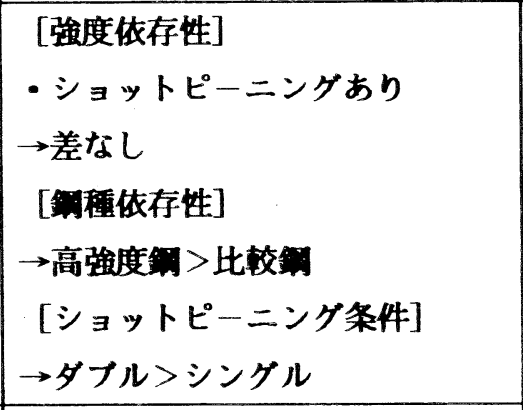 & 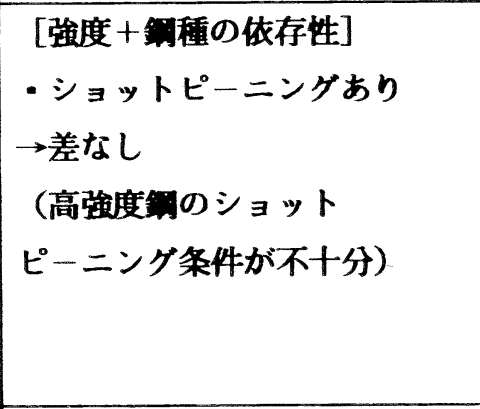 \\
\hline $\begin{array}{l}\text { ばねの } \\
\text { 度労起点 }\end{array}$ & $\begin{array}{l}\text { ばね内径䀣 } \\
\text { 介在物起点はなし }(0 ケ / 168 ケ) \\
\text { 内部ファセットもあり }\end{array}$ & $\begin{array}{l}\text { ばね内径㑡 } \\
\text { 介在物起点は若干あり (5ケ/912ケ) } \\
\text { 内部ファセットもあり }\end{array}$ & $\begin{array}{l}\text { ばね外径佩 } \\
\text { 介在物起点はなし(0ケ/72ケ) }\end{array}$ \\
\hline $\begin{array}{l}\text { 电晊の進展 } \\
\text { 方向 }\end{array}$ & $\begin{array}{l}\text { 最大愬断方向の初期龟裂から } \\
\text { 主态力方向へ進展 }\end{array}$ & $\begin{array}{l}\text { 主に最大紊断方向の初期裂から } \\
\text { 主応力方向へ進展し最終的には } \\
\text { 再ひ最大第断方向へ }\end{array}$ & $\begin{array}{l}\text { 主に主匛力方向の初期重裂から } \\
\text { 最大童断応力方向人 }\end{array}$ \\
\hline 耐へたり性 & 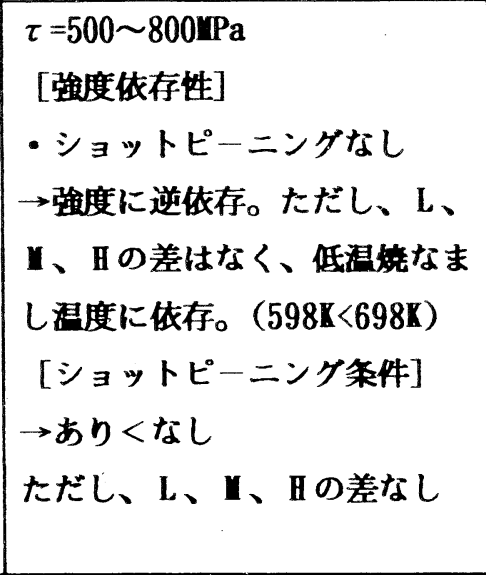 & 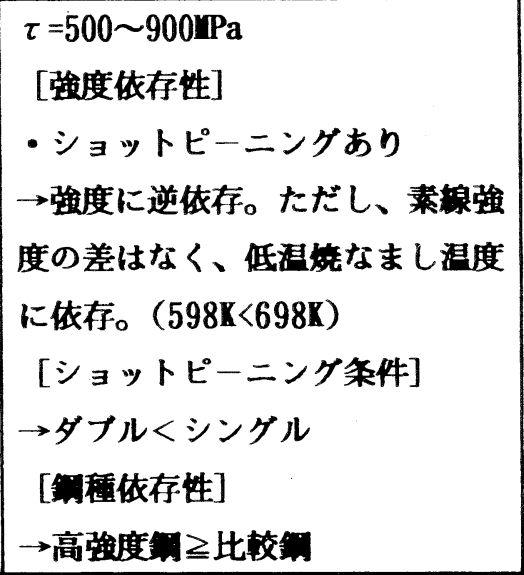 & 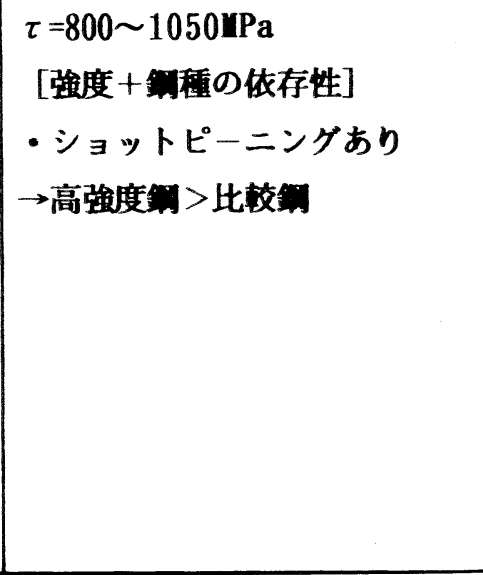 \\
\hline
\end{tabular}


度鋼と比較鋼であまり差が見られなかった。これは，一見 矛盾した現象のようであるが，弁ばねでもある適正な低温 焼なまし，ショットピーニング条件下では高強度鋼の優位 性が現れていること, 懸架ばねは締付け応力が比較的大き い領域で評価しており，締付け応力の小さい領域では高強 度鋼と比較鋼の差は小さくなることなどから矛盾はないと 思われる。ただし, 前述のように, ばね形状・寸法, 残留 応力分布, 負荷応力形態などの影響が考えられるため, 将 来さらに詳細な研究を行う必要がある。

なお，ばね技術研究会では過去に高強度鋼に関して，共 同研究 ${ }^{81}$, 14)，15)により調查を行っており，今回の結果との 比較が注目されたが, 過去のものはショットピーニングを 行っていない, SWOSC-Vを用いていない, などの理由か ら今回の結果との直接比較は不可能であった。

\section{参考文献}

1) Abe, M., Taniguchi, T., Kuriki, T., Saitoh, K., Takamura, N., SAE Technical Paper, Series 890220 (1989)

2) 高強度線の耐久性に関する調査研究委員会資料 222 No.2-1 (1991)

3）高強度線の耐久性に関する調査研究委員会，ばね技術研
究会1994年度春季講演会前刷集，39.

4）高強度線の耐久性に関する調査研究委員会，ばね論文集， No.39 (1993), 101.

5) Gassner, R. H., Metal Progress, March (1978), 59.

6）日本材料学会編，金属材料強度試験便覧（1977），231.

7）綾田倫彦，高村典利，ばね論文集，No.37，(1992)，59.

8）耐熱ばね材料委員会，ばね論文集，No.34，(1989)，59.

9）JIS B 0601 表面粗さ一定義及び表示

10）（社）日本ばね工業会，BANEX 解説編，1991

11）（社）日本ばね工業会，BANEX 操作編，1991

12）高強度線の耐久性に関する調查研究委員会, ばね論文 集, No.39 (1993), 67.

13）山田凱朗, 小新井治郎, 川口康信, 芦田真三, 日本金 属学会会報，23-6（1984），526。

14）自動車用弁ばねの耐久性能に関する共同研究委員会, ばね論文集，No.13（1968），1.

15）高強度鋼線委員会，ばね論文集，No.25（1980），51。

\section{付図}

本文に関連した付図 1 ～23，付表 1 を次頁以下に示す。 


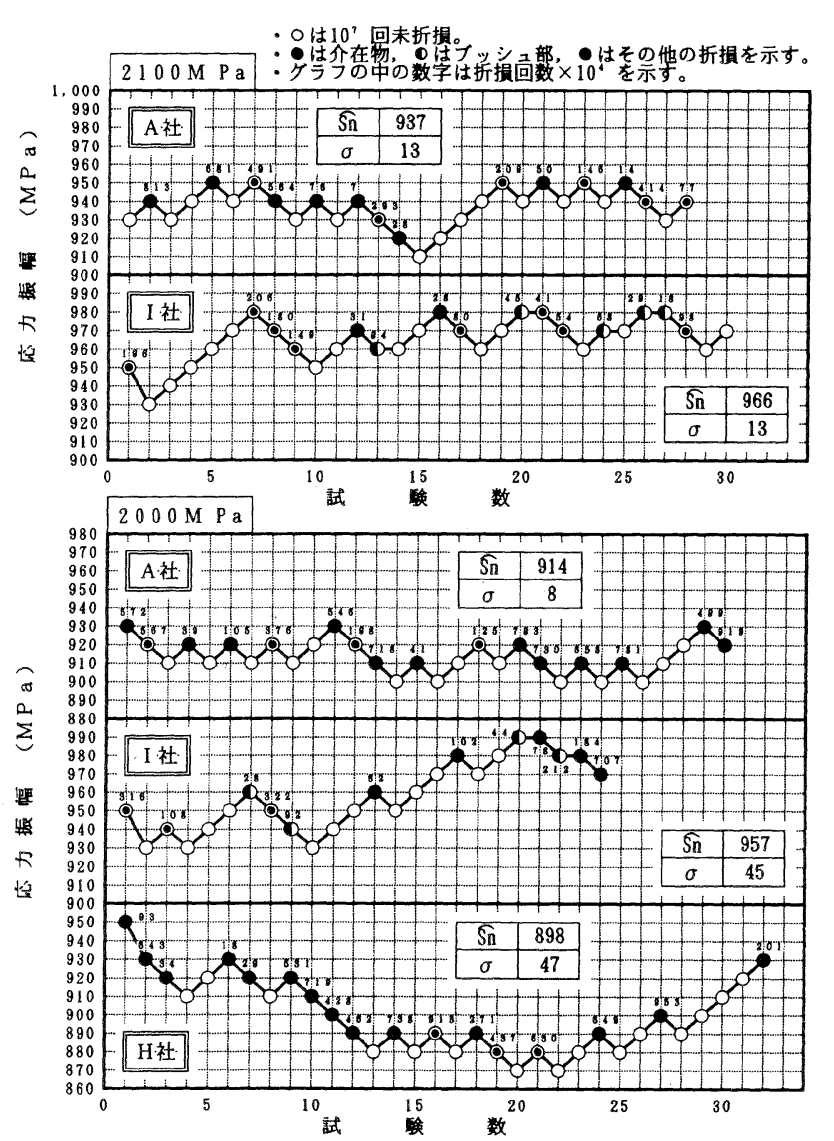

付図 1 中村式回転曲げ疲労試験結果（ステアケース法） - 1 次材, 高強度鋼，2100及び2000MPa材-

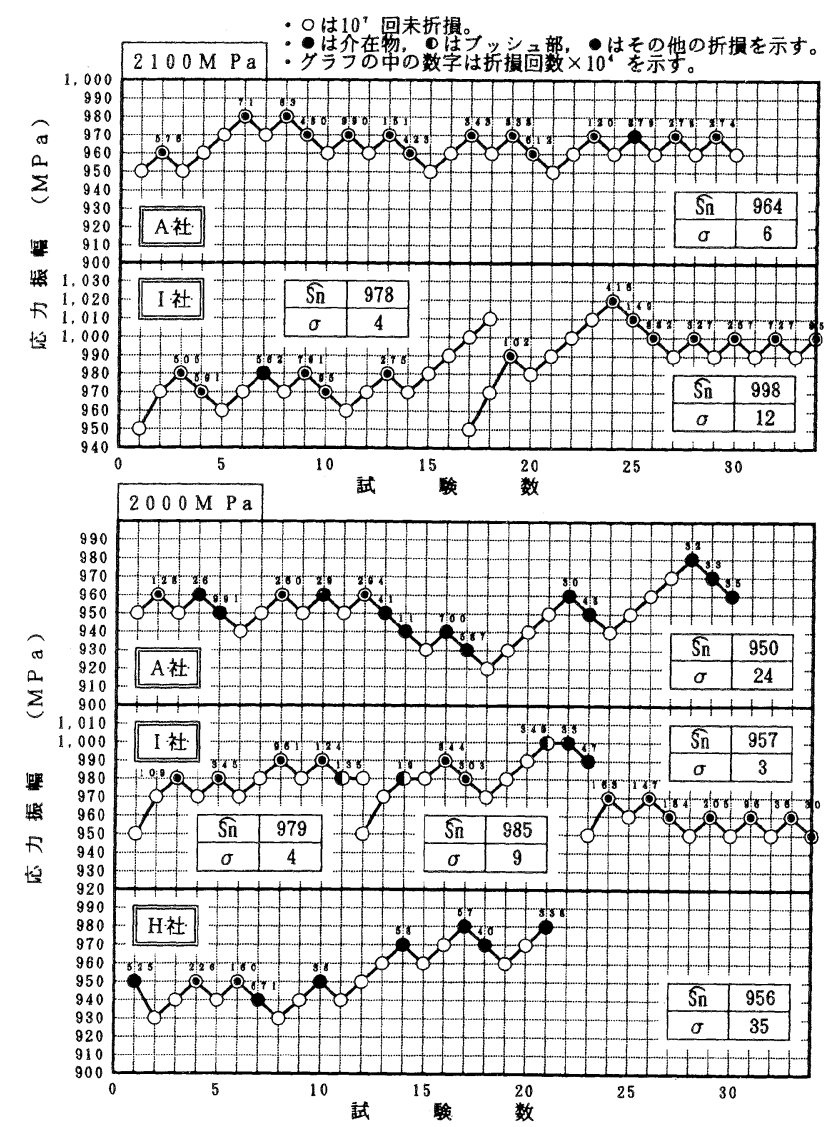

付図 3 中村式回転曲げ疲労試験結果（ステアケース法） - 2 次材, 高強度鋼, 2100 及び $2000 \mathrm{MPa}$ 材-
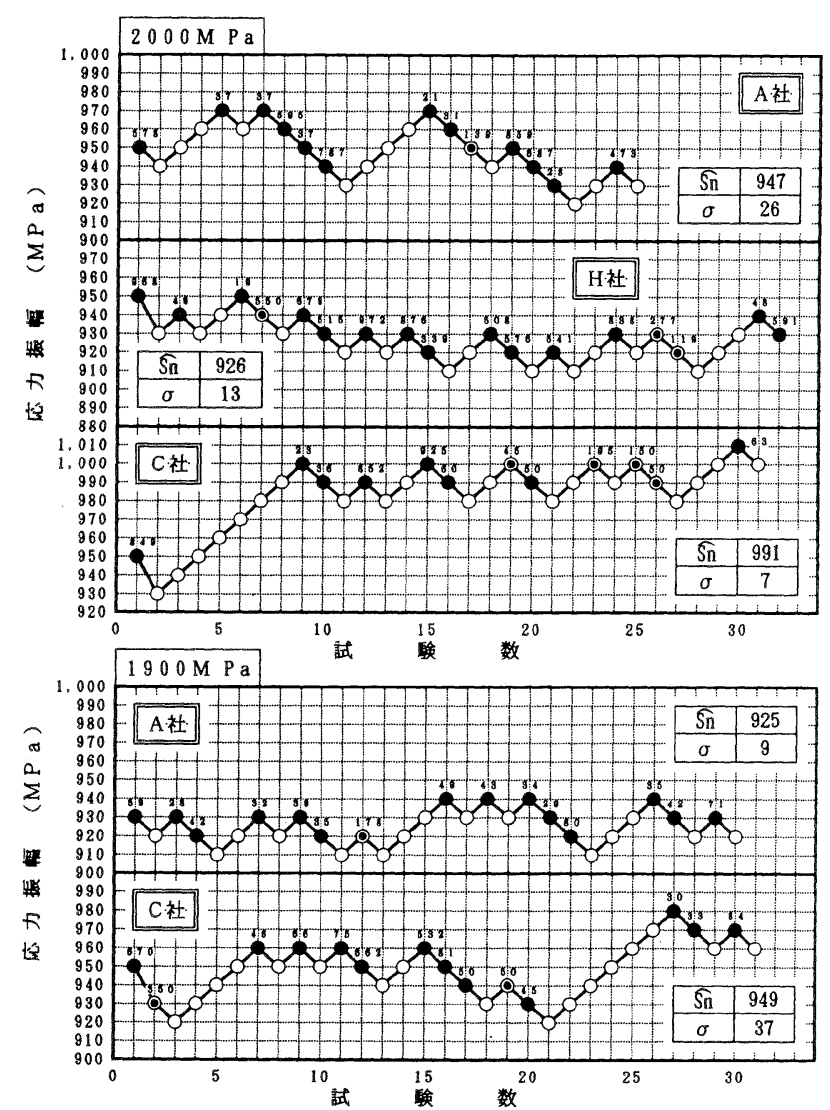

付図 2 中村式回転曲げ疲労試験結果（ステアケース法） - 1 次材, 比較鋼, 2000 及び $1900 \mathrm{MPa}$ 材-
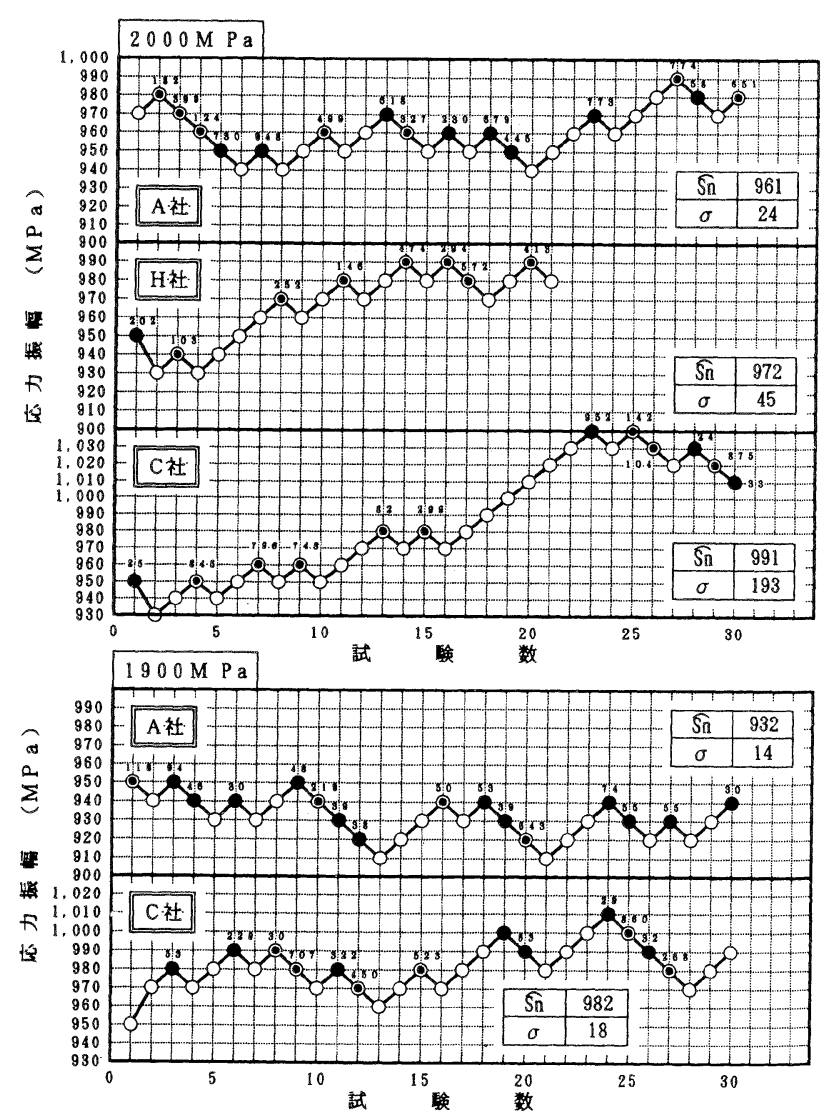

付図 4 .中村式回転曲げ疲労試験結果（ステアケース法） - 2 次材, 比較鋼, 2000及び1900MPa材- 


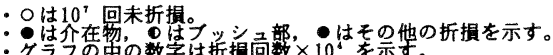

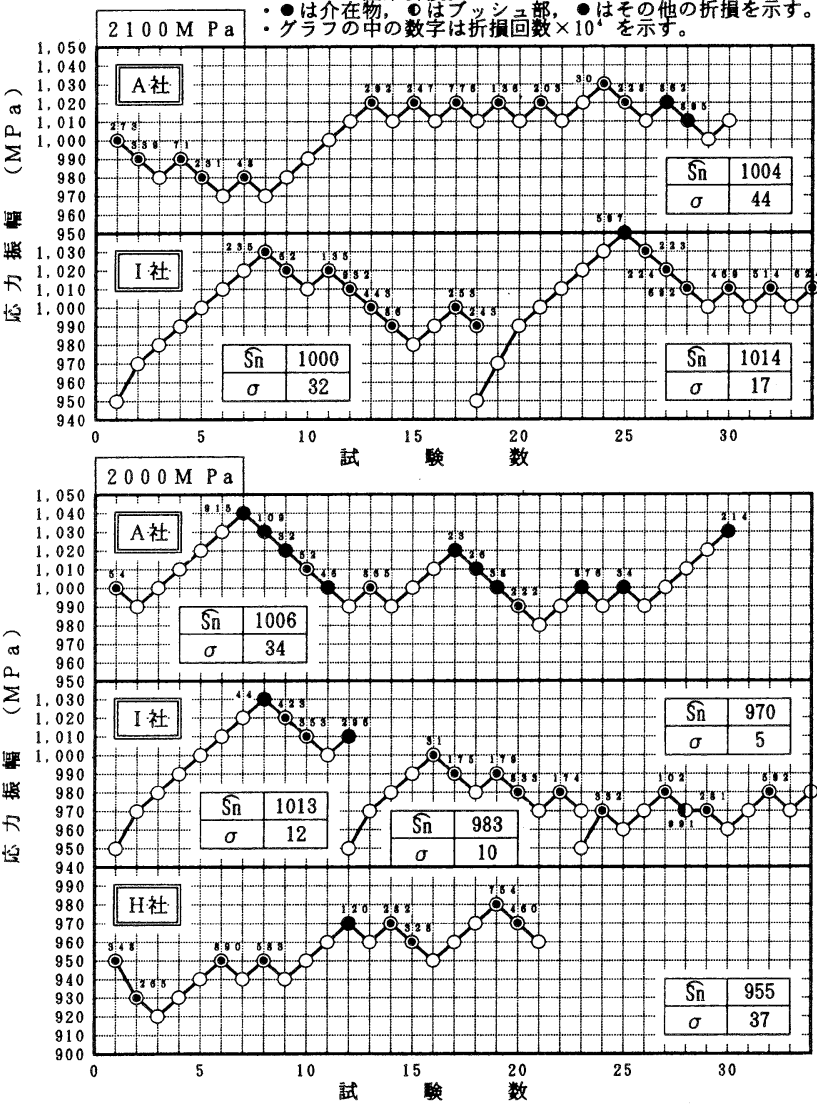

付図 5 中村式回転曲げ疲労試験結果（ステアケース法） - 3 次材, 高強度鋼, 2100 及び $2000 \mathrm{MPa}$ 材一
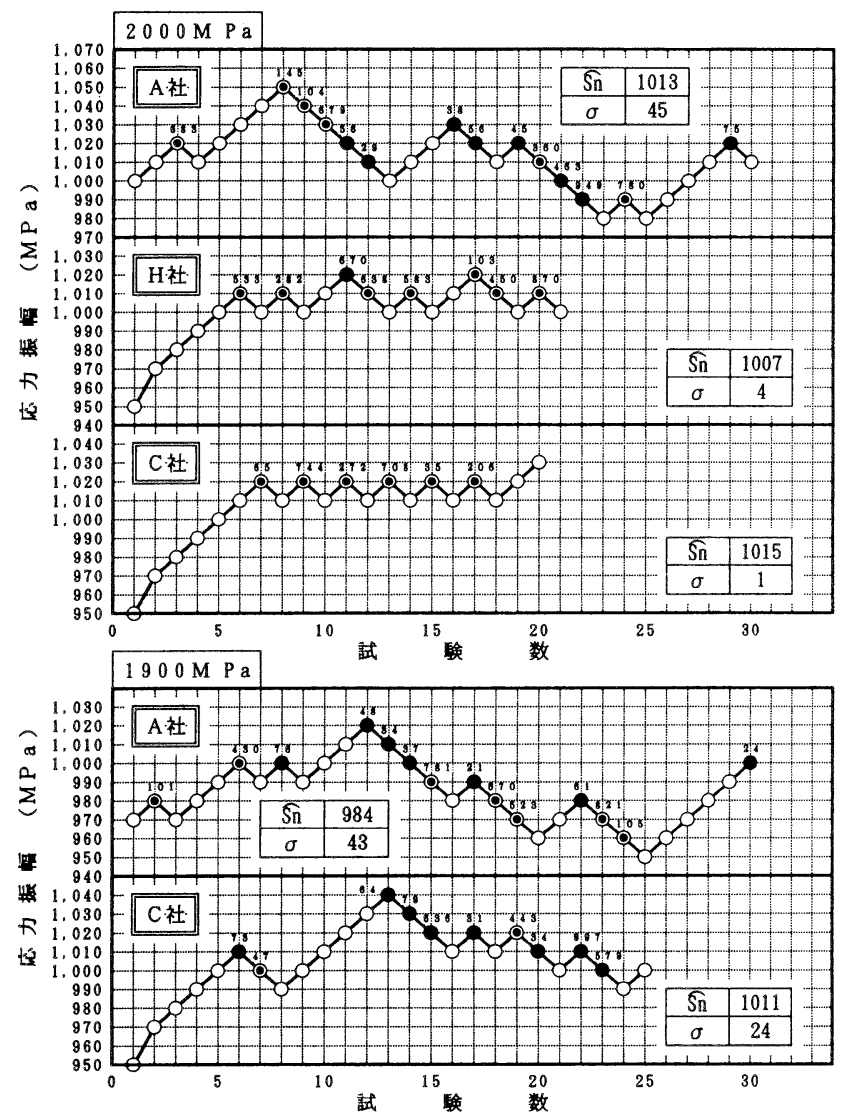

付図 6 中村式回転曲げ疲労試験結果 (ステアケース法) -3 次材, 比較鋼，2000及び $1900 \mathrm{MPa}$ 材—

付表 1 中村式回転曲げ疲労試験（ステアケース法）に招ける介在物による折損率 (介在物折損本数 /折損本数)

\begin{tabular}{|c|c|c|c|c|c|c|c|c|c|}
\hline \multirow[t]{2}{*}{ 処 理 } & \multirow[t]{2}{*}{ 鏩種 } & \multirow{2}{*}{$\begin{array}{c}\text { 蜋レペレ } \\
\text { IPa }\end{array}$} & \multirow[t]{2}{*}{ 呼称 } & \multicolumn{2}{|r|}{$\mathbf{5 1}$} & \multicolumn{2}{|l|}{ 会 } & \multicolumn{2}{|c|}{ 合 計折損率 } \\
\hline & & & & $\Lambda$ 住 & I隹 & 睢 & C & & (x) \\
\hline \multirow{4}{*}{$\begin{array}{l}1 \text { 次 材 } \\
\left(\begin{array}{l}698 \mathrm{~K} \\
\text { シンタn } \\
\text { ショタト }\end{array}\right)\end{array}$} & \multirow[t]{2}{*}{ 高強度金 } & 2100 & H21 & $6 / 14$ & $8 / 15$ & - & 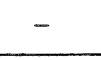 & $14 / 29$ & 48.3 \\
\hline & & 2000 & H20 & $4 / 16$ & $3 / 12$ & $3 / 17$ & - & $10 / 45$ & 22.2 \\
\hline & \multirow[t]{2}{*}{ 比较金 } & 2000 & $\mathbf{s} 20$ & $2 / 13$ & - & - & $4 / 12$ & $9 / 42$ & 21.4 \\
\hline & & 1900 & S19 & $1 / 15$ & - & - & $2 / 14$ & $3 / 29$ & 10.4 \\
\hline \multirow{4}{*}{$\begin{array}{l}2 \text { 次 材 } \\
\left(\begin{array}{l}598 \mathrm{~K} \\
\text { シンタn } \\
\text { ショット }\end{array}\right)\end{array}$} & \multirow[t]{2}{*}{ 高強度金 } & 2100 & н21 & $13 / 14$ & $13 / 14$ & - & - & $26 / 28$ & 92.9 \\
\hline & & 2000 & н20 & $3 / 15$ & $12 / 14$ & $2 / 9$ & - & $17 / 38$ & 44. 7 \\
\hline & \multirow[t]{2}{*}{ 比较场 } & 2000 & S20 & $7 / 15$ & - & $7 / 8$ & $8 / 12$ & $22 / 35$ & 62.9 \\
\hline & & 1900 & S19 & $4 / 16$ & - & - & $6 / 12$ & $10 / 28$ & 35.7 \\
\hline \multirow{4}{*}{$\begin{array}{l}3 \text { 次 材 } \\
\left(\begin{array}{l}598 \mathrm{~K} \\
47 k \\
\text { घョ }^{2}\end{array}\right)\end{array}$} & \multirow[t]{2}{*}{ 高強度全 } & 2100 & H21 & $12 / 14$ & $14 / 15$ & - & - & $26 / 29$ & 89.7 \\
\hline & & 2000 & H20 & $4 / 14$ & $11 / 13$ & $8 / 9$ & - & $23 / 36$ & 63.9 \\
\hline & \multirow[t]{2}{*}{ 比较金 } & 2000 & s20 & $6 / 14$ & - & $7 / 8$ & $6 / 6$ & $19 / 28$ & 67.9 \\
\hline & & 1900 & S19 & $7 / 14$ & - & - & $2 / 10$ & $9 / 24$ & 37.5 \\
\hline
\end{tabular}




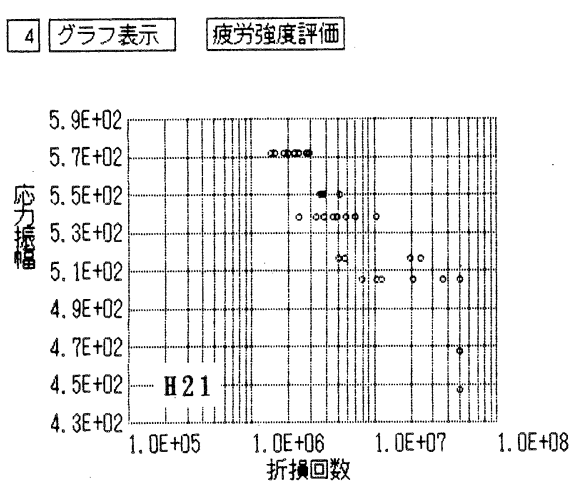

\section{4 グラフ表示 疲労強度評佃}

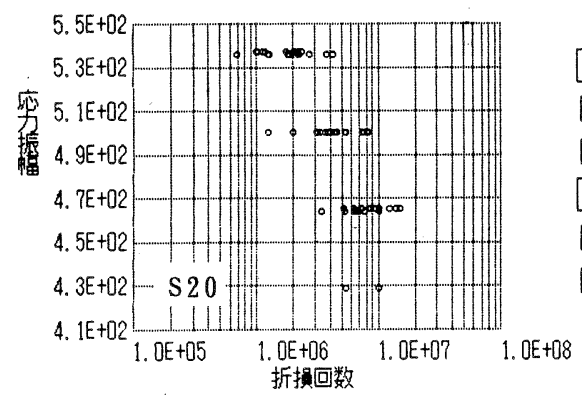

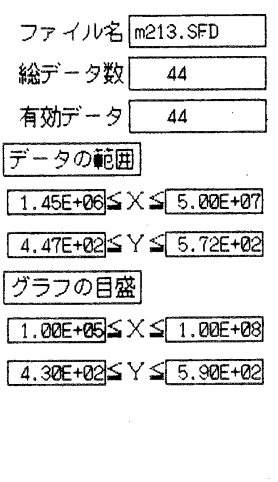

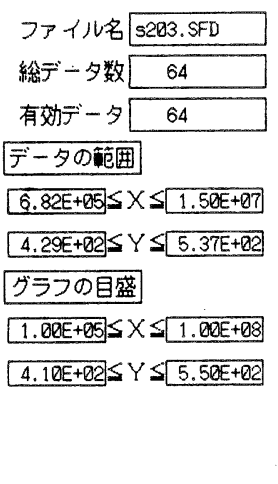

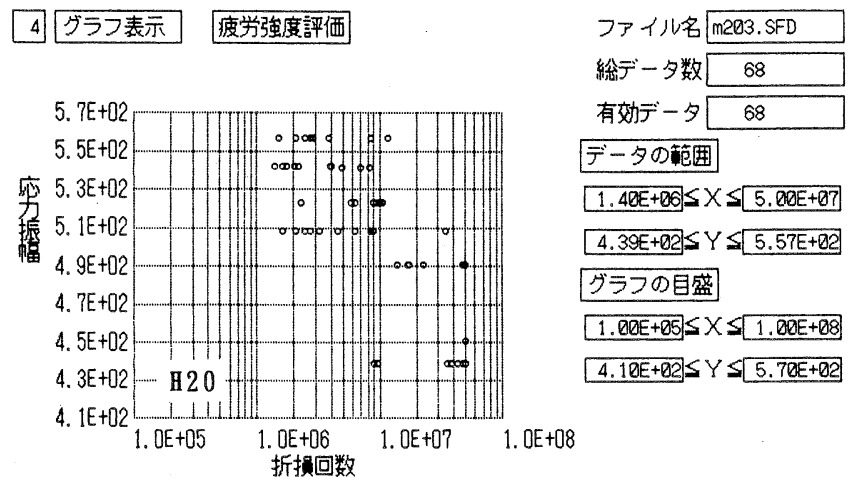

\section{4 グラフ表示 疲労強度評佃}

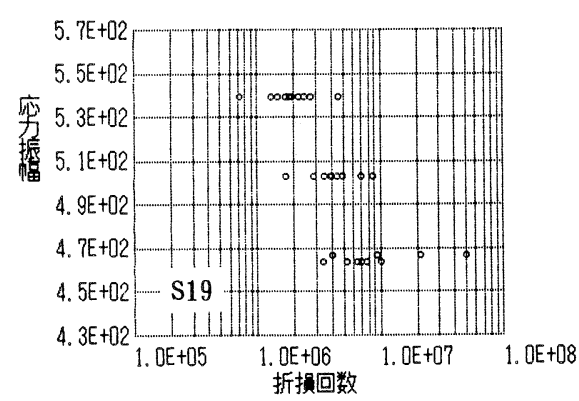

ファイル名 S193.SFD 総デー多数 36

有效デー夕级 データの舫囲

$7.19 E+25 \leq x \leq 5.80 E+07$ $4.64 E+82 \leq Y \leq 5.39 E+02$ グラフの目盛

$1.00 E+05 \leq X \leq 1.00 E+08$ $4.30 E+[2] \leq Y \leq 5.70 E+02$

付図 7 ばね 1 次材の星型疲労試験結果 $\tau_{m}=600 \mathrm{MPa}$

\section{4] グラフ表示 疲学強度評㑑}

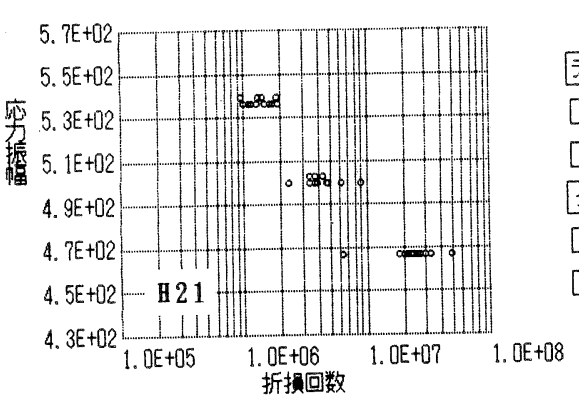

\section{4 グラフ表示 疲学強度評価}

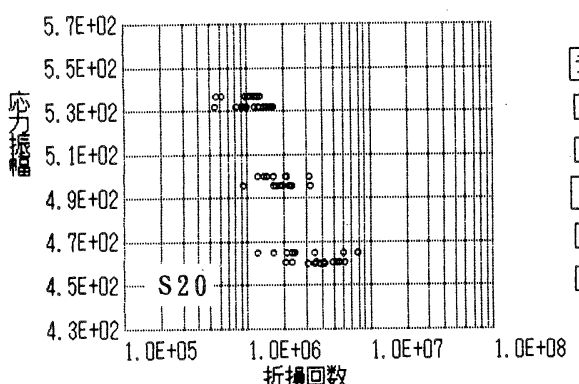

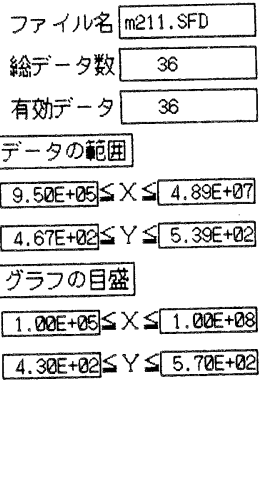

ファイル名 S201.SFD 総デー夕数 60 有効データ 60 データの篗团 $5.47 E+05 \leq X \leq 7.86 E+06$ $4.68 E+02] \leq Y \leq 5.37 E+02$ グラフの目盛 $1.08 E+05 \leq X \leq 1.00 E+88$ $4.38 E+02] \leq Y \leq 5.70 E+82$

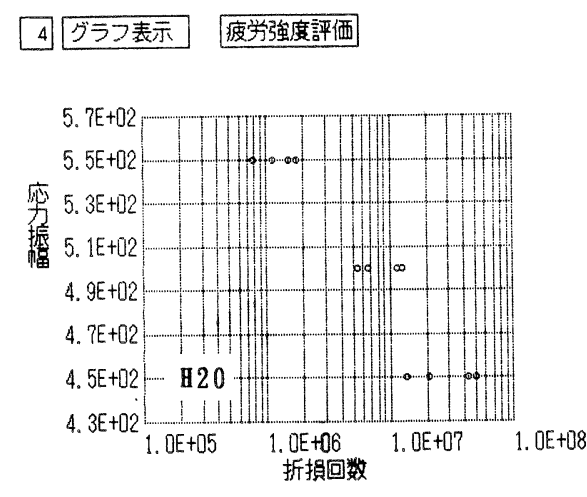

ファイル名 $\mathrm{m} 201 \mathrm{~s}$. SFD 総デー多数 12 有効データ 12 データの䑦囲

$7.80 E+05 \leq X \leq 5.00 E+07$ $4.58 E+02 \leq Y \leq 5.50 E+02$ グラフの目盛

$1.00 E+05 \leq X \leq 1.00 E+08$ $4.30 E+02 \leq Y \leq 5.70 E+02$

\section{4 グラフ表示 疲労強度評価}

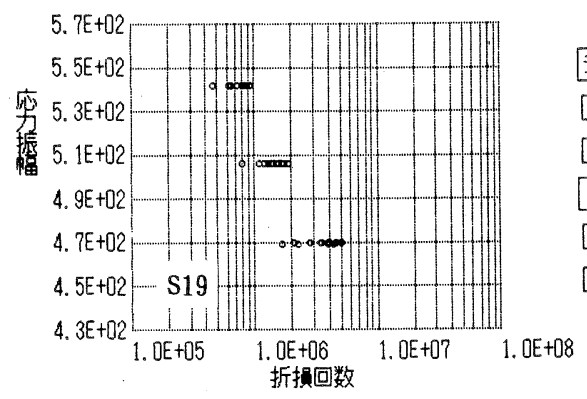

ファイル名 S191.SFD 総デー夕数 37

有効データ 37 デー夕の舱团

$7.50 \mathrm{E}+04 \leq X \leq 5.08 \mathrm{E}+06$ $1.82 E+02 \leq Y \leq 5.42 E+02$ グラフの目盛

$1.00 E+05 \leq X \leq 1.00 E+08$ $4.38 E+02 \leq Y \leq 5.70 E+02$

付図 8 ばね 2 次材の星型疲労試験結果 $\tau_{m}=600 \mathrm{MPa}$ 


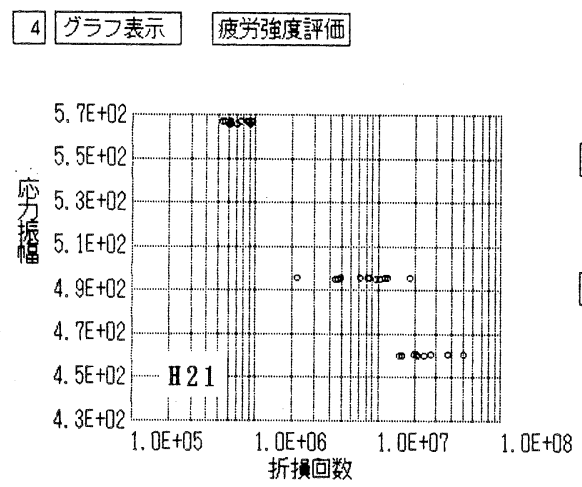

\section{4 グラフ表示 疲労強度評㑑}

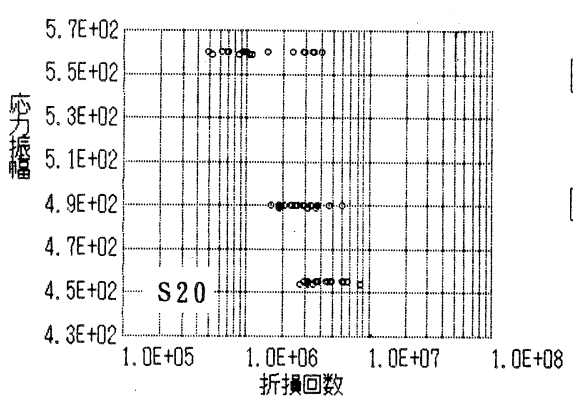

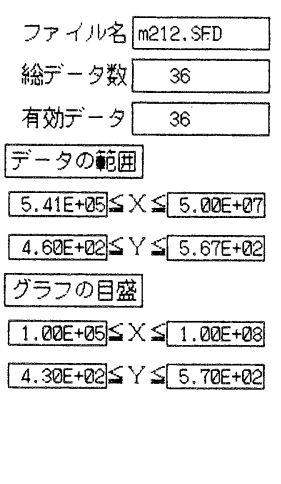

\section{4 グラフ表示 疲学強度評佃}

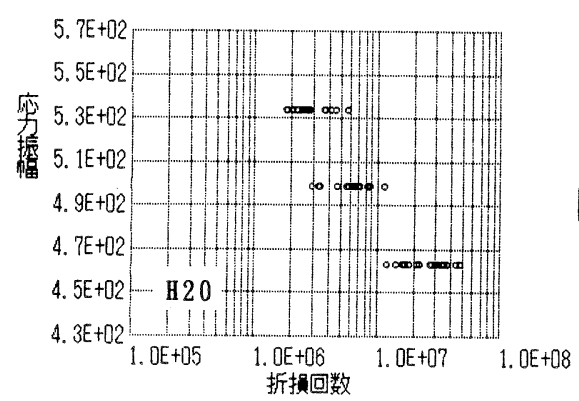

ファイルタ M202.SFD

総デー夕数 60

有效デー夕 60

データの䟭囲

$1.79 E+06 \leq X \leq 4.76 E+07$

$4.63 E+02] \leq Y \leq 5.34 E+02$

グラフの目盛

$1.08 E+05 \leq x \leq 1.00 E+08$

$4.30 E+02 \leq Y \leq 5.70 E+02$

付図 9 ばね 3 次材の星型疲労試験結果 $\tau_{m}=600 \mathrm{MPa}$

\section{4 グラフ表示 疲労強度評㑑}

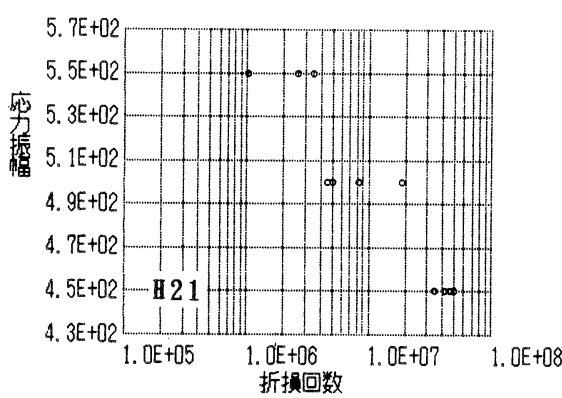

\section{4 グラフ表示 疲労強度評㑑}

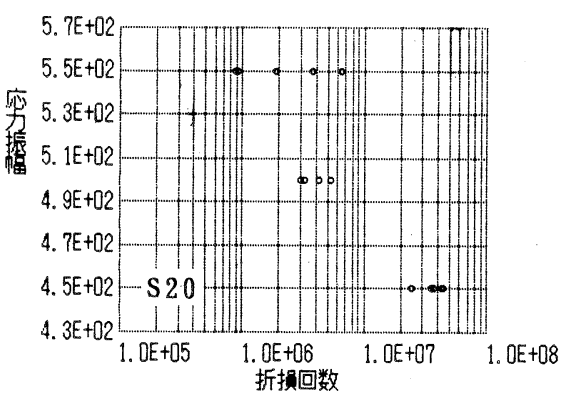

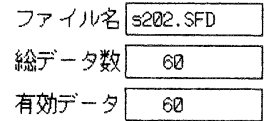

データの䚀团

$4.85 E+05 \leq x \leq 8.45 E+26$

$4.54 E+Q 2] \leq Y \leq 5.68 E+Q 2]$

グラフの目盛

$1.00 \mathrm{E}+0.5 \leq \mathrm{X} \leq 1.00 \mathrm{E}+08$

$4.3[E+[Q] \leq Y \leq 5.70 E+[2]$

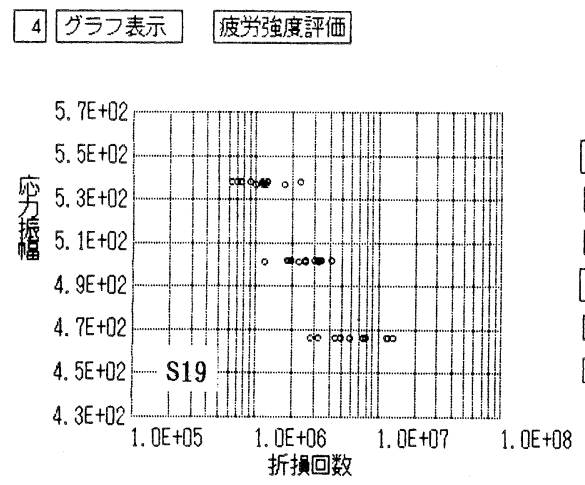

ファイル它 S192.SFD

総デー夕数 36

有効デー夕

F゙ータの籍团

$6.44 E+05 \leq X \leq 1.32 E+07$

$4.66 E+02 \leq Y \leq 5.38 E+02$

グラフの目盛

$1.00 E+05 \leq x \leq 1.00 E+08$

$4.30 E+82 \leq Y \leq 5.70 E+02$

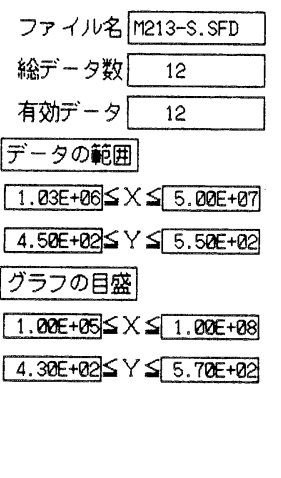

ファイル名 S203-S.SFD

総デー夕数 14

有効デー夕 14

F゙ータの籍团

$8.86 E+85 \leq x \leq 4.41 E+07$

$4.58 E+02] \leq Y \leq 5.50 E+82$

グラフの目盛

$1.08 E+85 \leq X \leq 1.08 E+28$

$4.30 E+02 \leq Y \leq 5.78 E+02$
4 グラフ表示 疲学蚛度語㑑

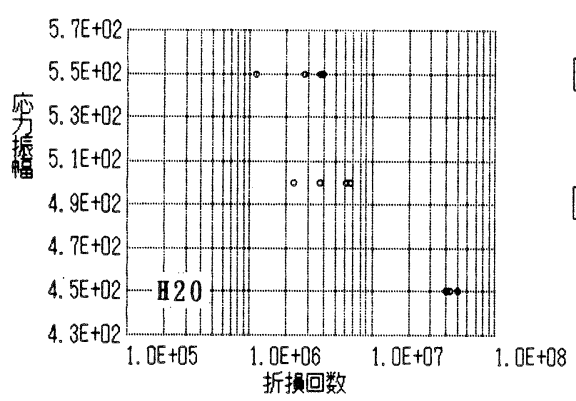

\section{4 グラフ表示 疲学強度俨佃}

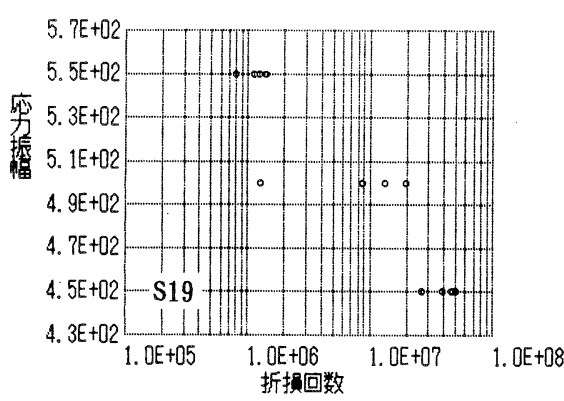

ファイル它 M203-S.SFD

総デー夕数 12

有效デー夕 12

データの䨋聿

$1.13 E+06 \leq X \leq 5.08 E+07$

$4.58 E+82 \leq Y \leq 5.50 E+62$

グラフの目盛

$1.00 E+055 X \leq 1.08 E+08$

$4.30 E+82] \leq Y \leq 5.70 E+02$

付図 10 ばね 1 次材の油圧サーボ型疲労試験結果 $\tau_{m}=600 \mathrm{MPa}$ 

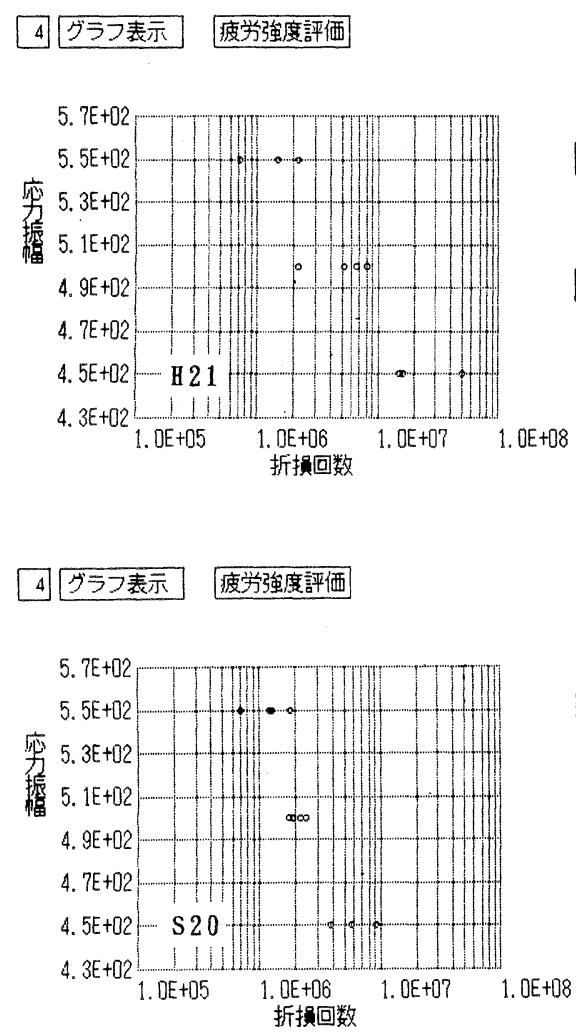

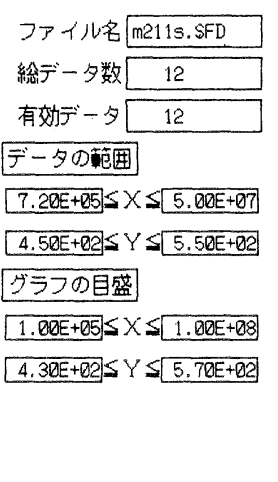

ファイル名 S2015.SFD
総データ数 12
有効データ 12 デー夕0䖝团

$7.00 E+05 \leq X \leq 9.19 E+06$

$4.50 E+02 \leq Y \leq 5.50 E+02$

グラフの目盛

$1.00 E+05 \leq x \leq 1.00 E+08$

$4.30 E+02 \leq Y \leq 5.70 E+02$

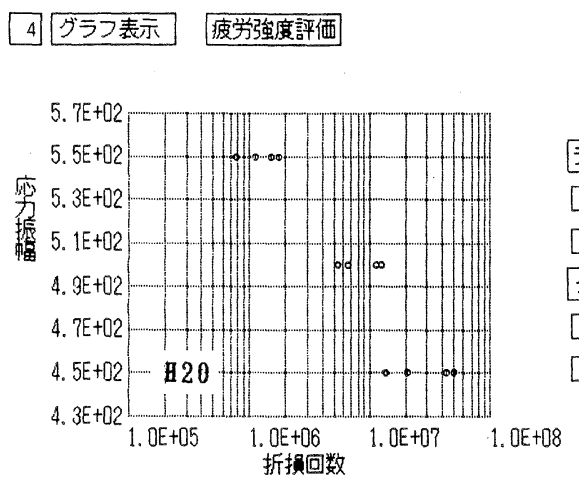

ファイル名 m2015.SFD

総デー夕数 12

有効デー夕 12

デー夕の航团

$7.80 E+05 \leq X \leq 5.00 E+07$

$4.50 E+02 \leq Y \leq 5.50 E+02$

グラフの目盛

$1.00 E+05 \leq X \leq 1.00 E+08$

$4.30 E+02 \leq Y \leq 5.70 E+02$

付図 11 ばね 2 次材の油圧サーボ型疲労試験結果 $\tau_{m}=600 \mathrm{MPa}$

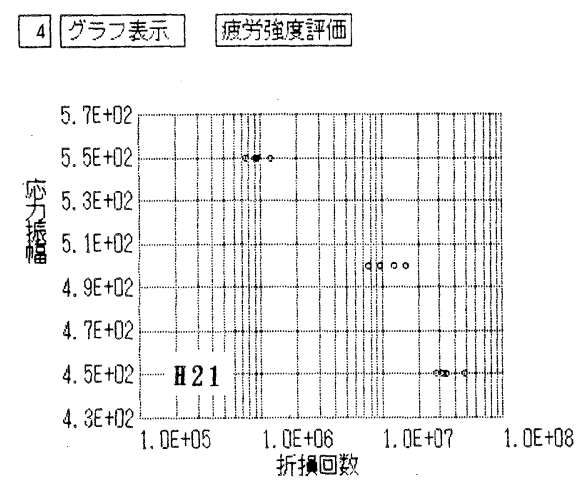

\section{4 ク5ラフ表示, 疲学強度評佃}

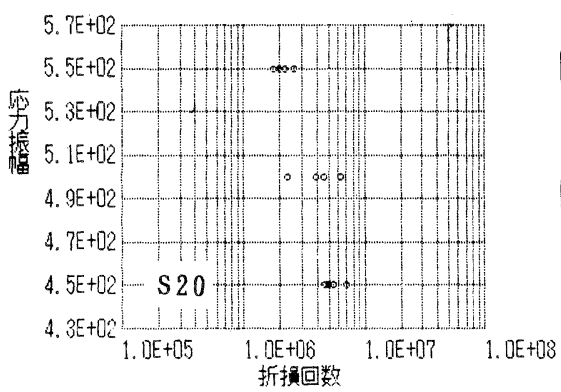

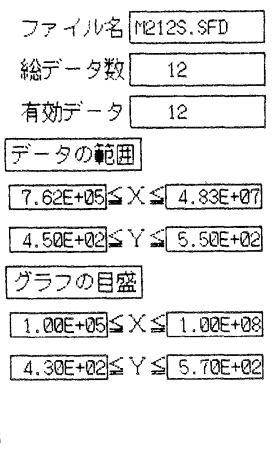

$$
\begin{aligned}
& \text { ファイル多 \$202S.SFD } \\
& \text { 総データ数 } 12 \\
& \text { 有效データ } 12
\end{aligned}
$$$$
\text { F゙ータの野团 }
$$

$1.74 E+06 \leq \times \leq 7.01 E+06$

$4.50 E+[2] \leq Y \leq 5.50 E+02$

グラフ0目盛

$1.00 E+855 X \leq 1.00 E+08$

$4.30 E+02 \leqq Y \leq 5.70 E+02$
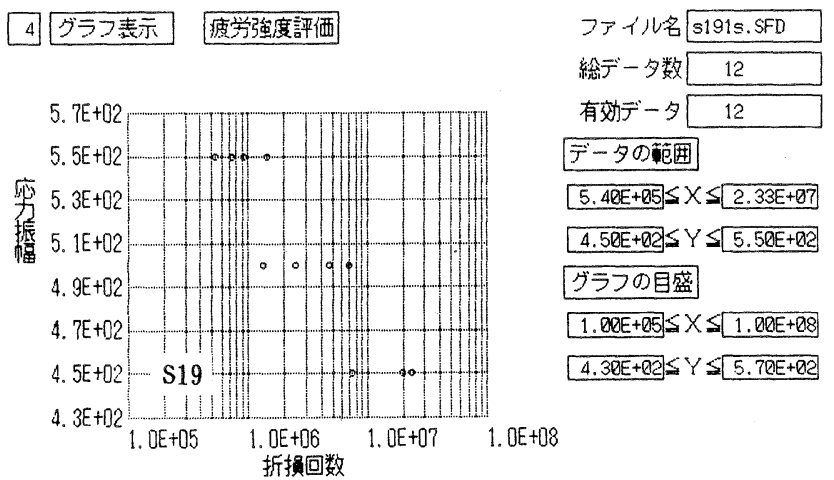

$5.48 E+85 \leq X \leq 2.33 E+07$ $4.50 E+82 \leq Y \leq 5.50 E+02$ グラフの目盛

$1.00 E+05 \leq x \leq 1.00 E+08$ $4.38 E+Q 2] \leq Y \leq 5.70 E+02$

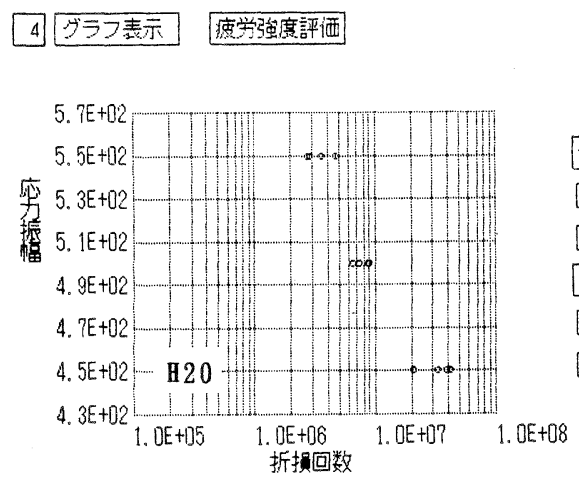

ファイル名 M202S.SFD

総デー夕数 12

有效デー夕 12

データ0筙国

$2.74 E+06 \leq x \leq 4.17 E+07$

$4.50 E+02 \leq Y \leq 5.50 E+02$

भララの目盛

$1.00 E+05 \leq X \leq 1.00 E+08$

$4.30 E+02 \leq Y \cong 5.70 E+02$

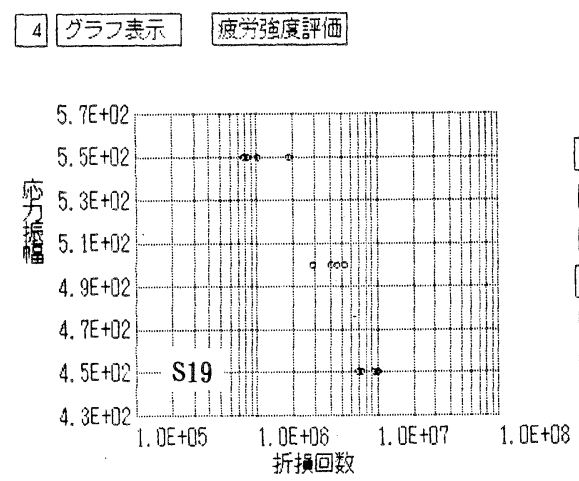

ファイイ名 \$192S.SFD

総デー多数 12

有效デー夕 12

データの船囲

$7.69 E+05 \leq x \leq 1.02 E+07$

$4.50 E+02 \Omega 5=5.50 E+02$

グラフの目盛

$1.00 E+025 \leq \times \leq 1.00 E+08$

$4.30 E+02 \leq Y \leq 5.70 E+02$

付図 12 ばね 3 次材の油圧サーボ型疲労試験結果 $\tau_{m}=600 \mathrm{MPa}$ 

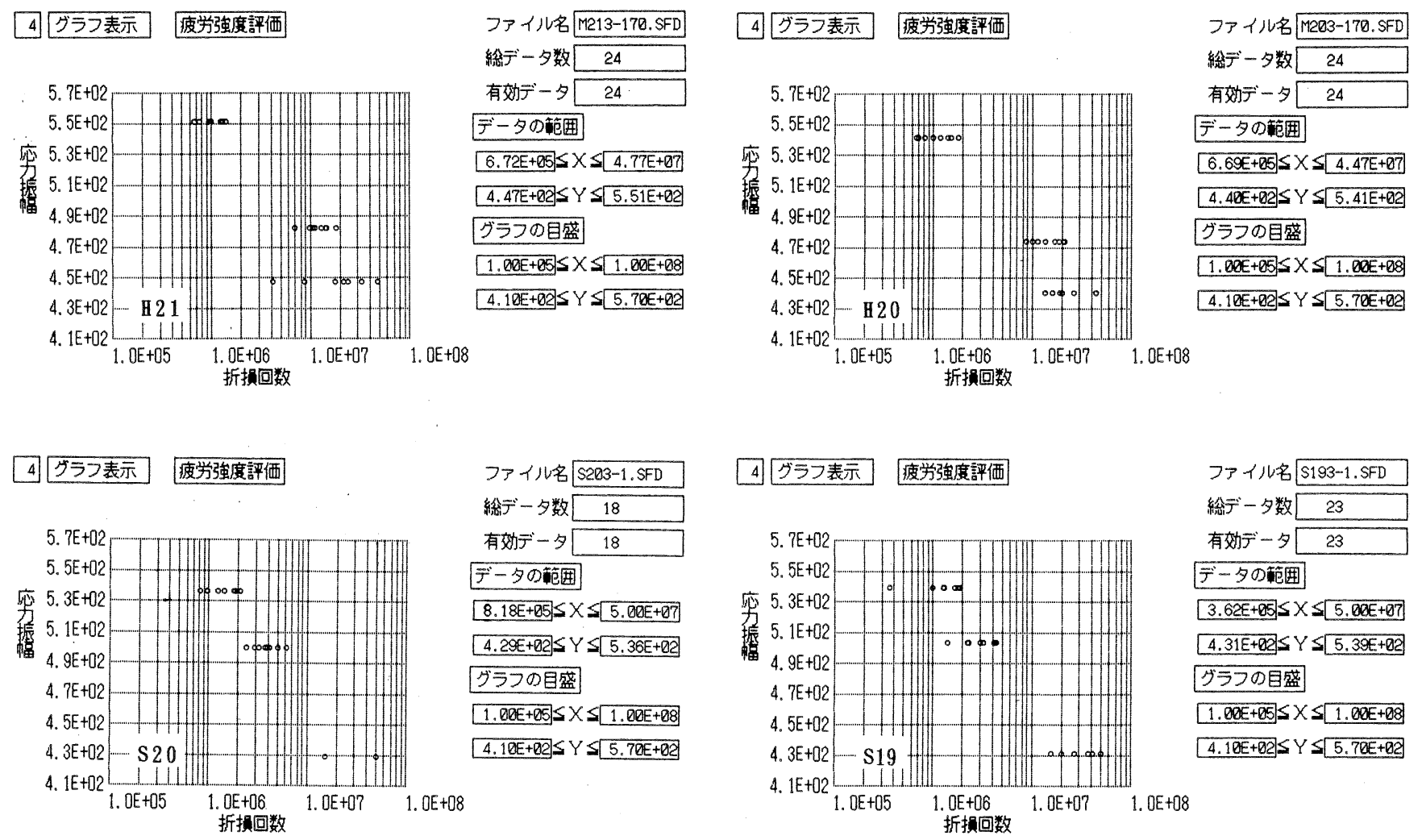

付図 13 ばね 1 次材の星型疲労試験結果 $\tau_{m}=700 \mathrm{MPa}$
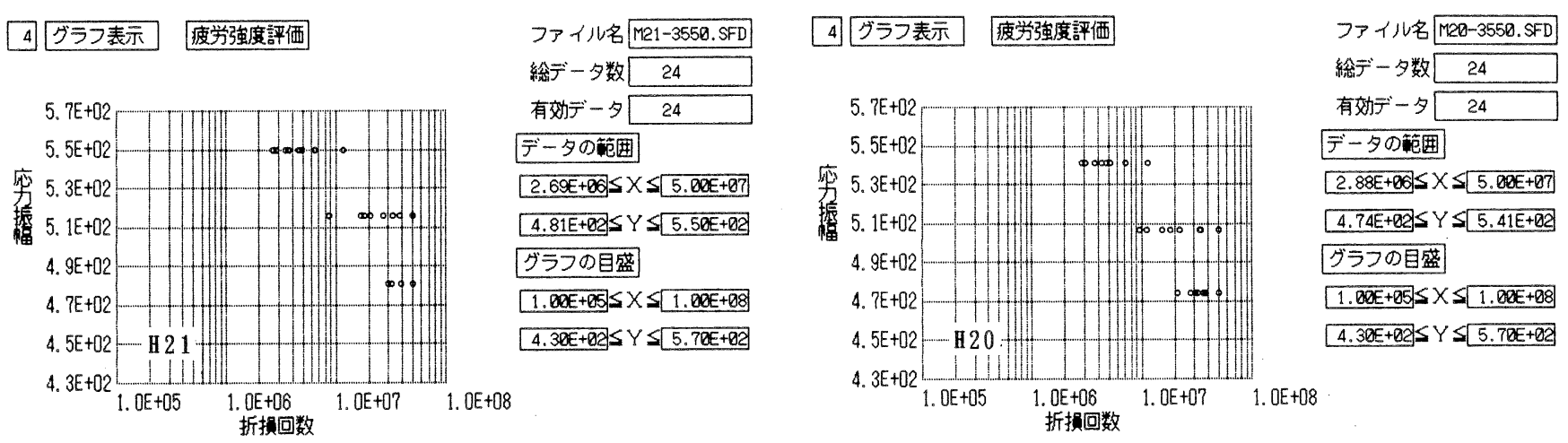

\section{4}

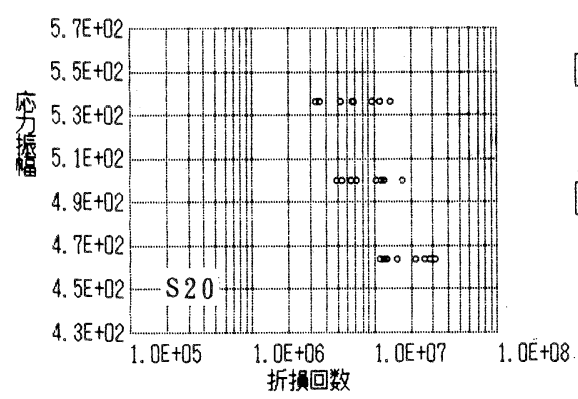

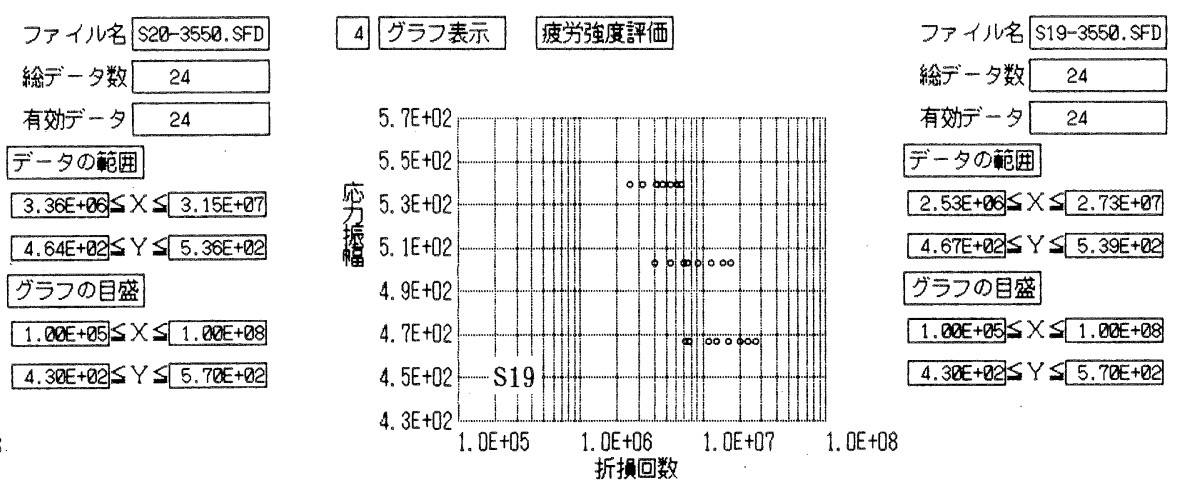

付図 14 ば敉1 次材の星型疲労試験結果 $\tau_{m}=550 \mathrm{MPa}$ 

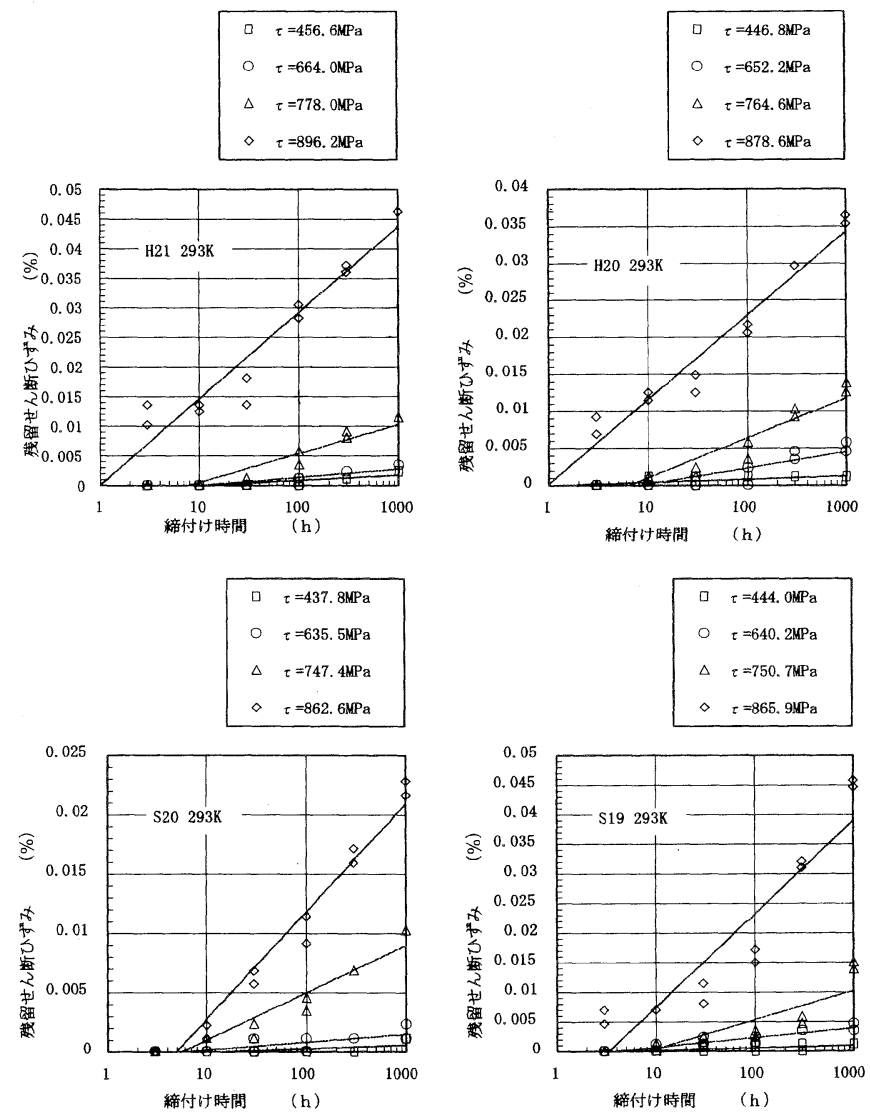

付図 15 残留せん断ひずみと締付け時間の関係

(1 次材， $293 \mathrm{~K}$ ，応力修正係数なし)
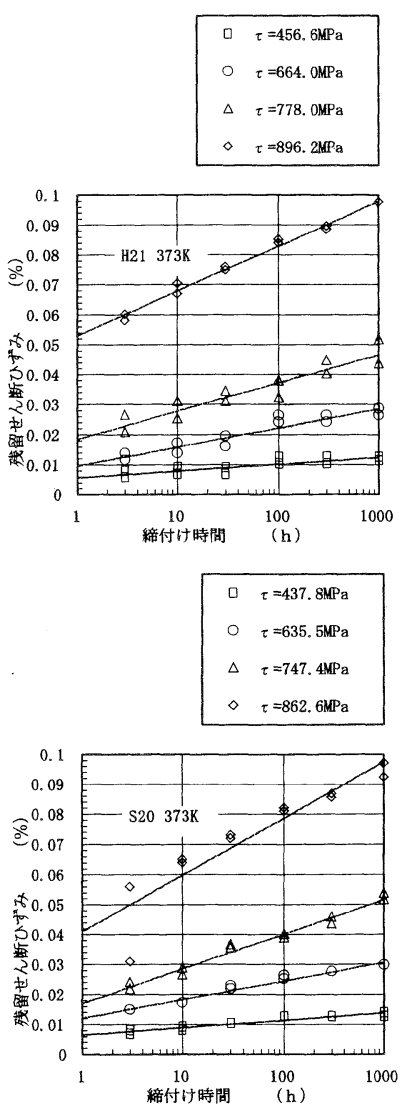
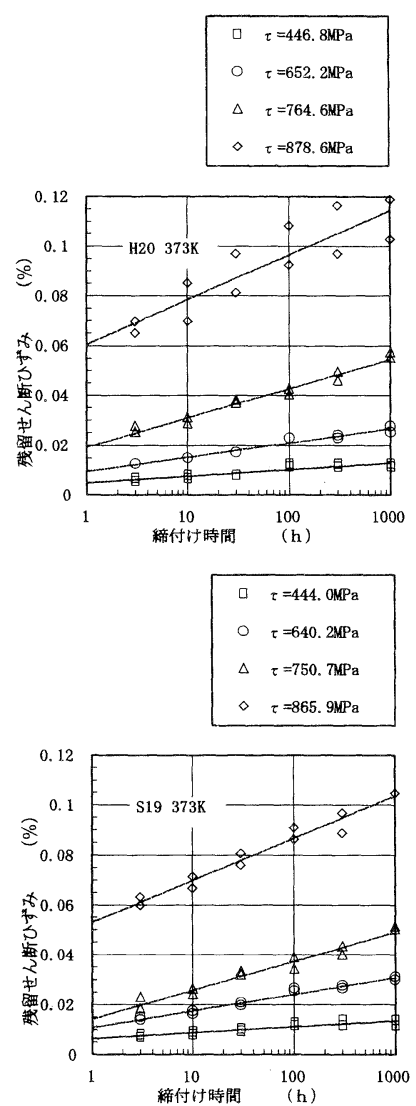

付図 16 残留せん断ひずみと締付け時間の関係 (1 次材, $373 \mathrm{~K}$, 応力修正係数なし)
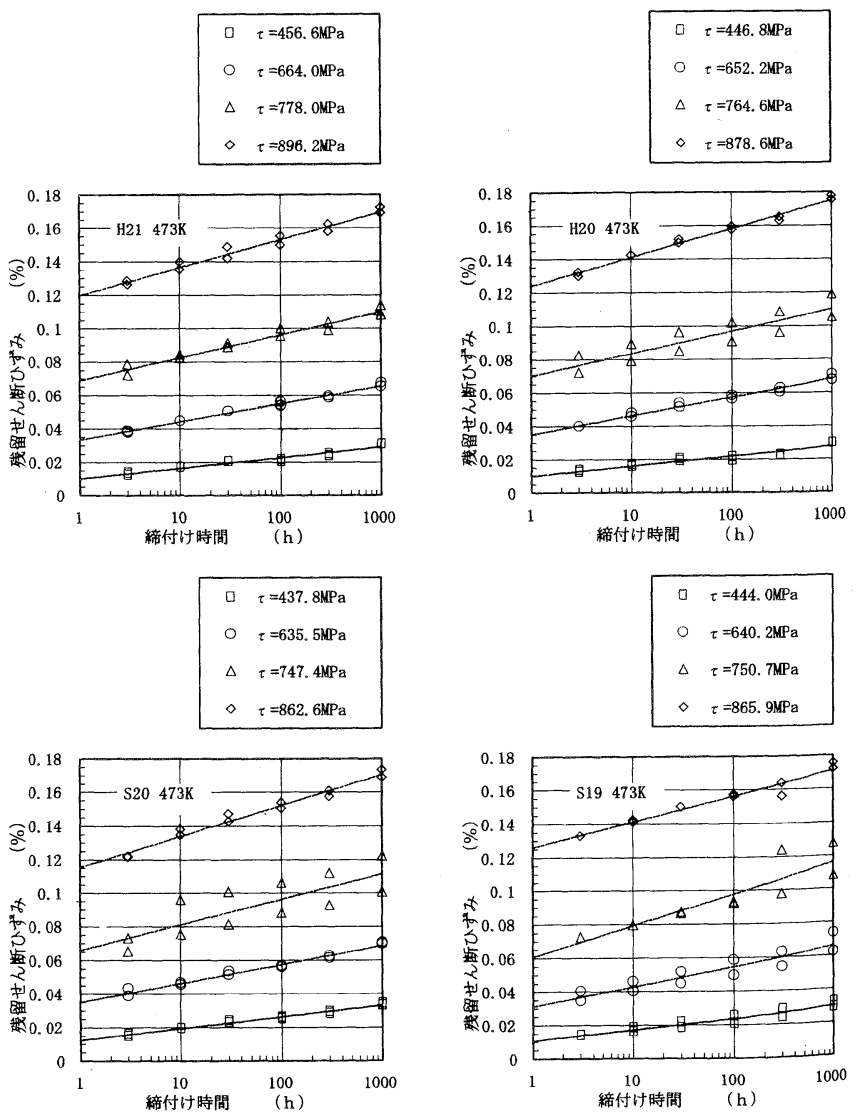

付図 17 残留せん断ひずみと締付け時間の関係 (1 次材， $473 \mathrm{~K}$ ，応力修正係数なし) 

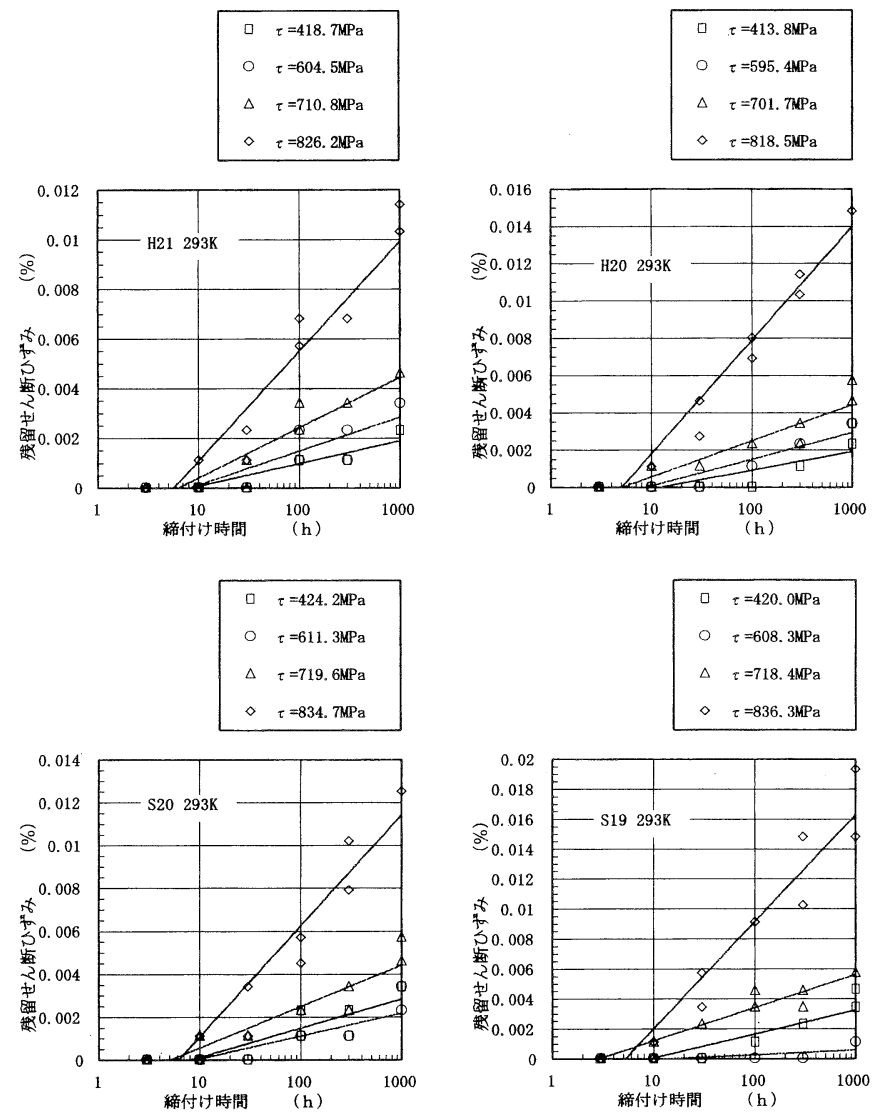

付図 18 残留せん断ひずみと締付け時間の関係 (2 次材, $293 \mathrm{~K}$, 応力修正係数なし)
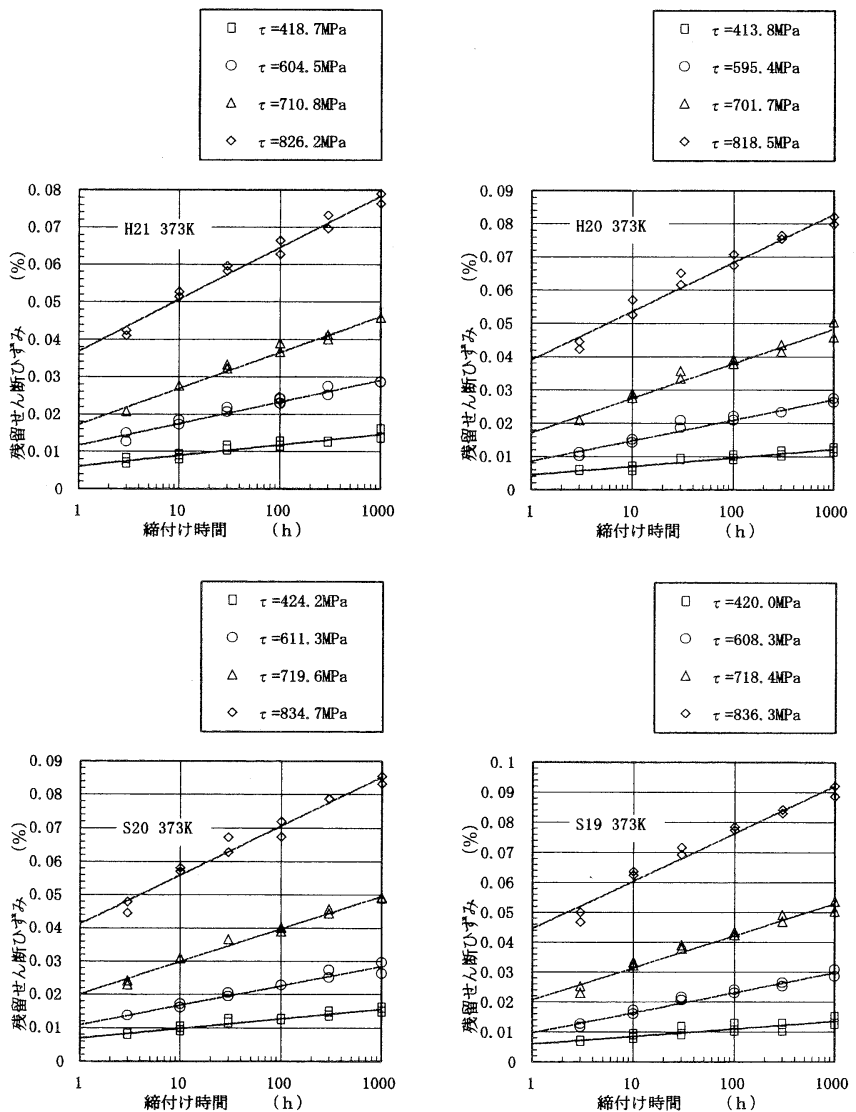

付図 19 残留せん断ひずみと締付け時間の関係 ( 2 次材, $373 \mathrm{~K}$, 応力修正係数なし)
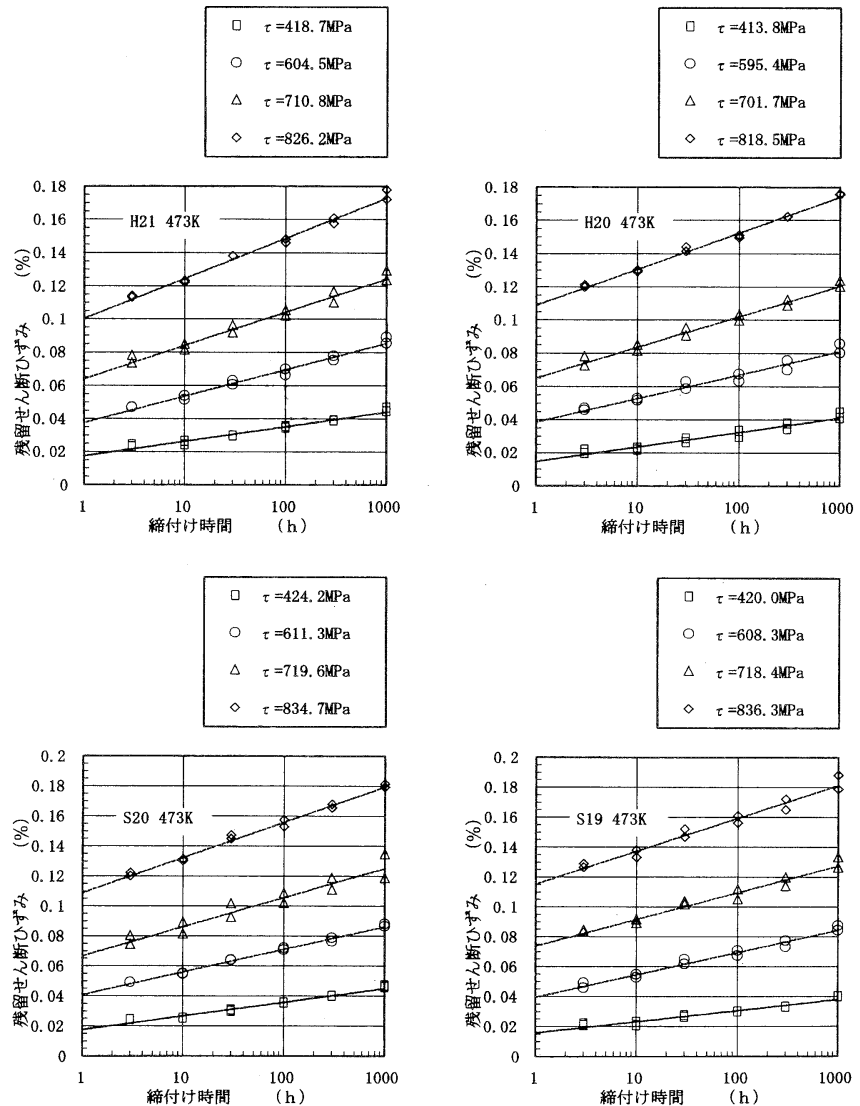

付図 20 残留せん断ひずみと締付け時間の関係 (2 次材, $473 \mathrm{~K}$, 応力修正係数なし) 

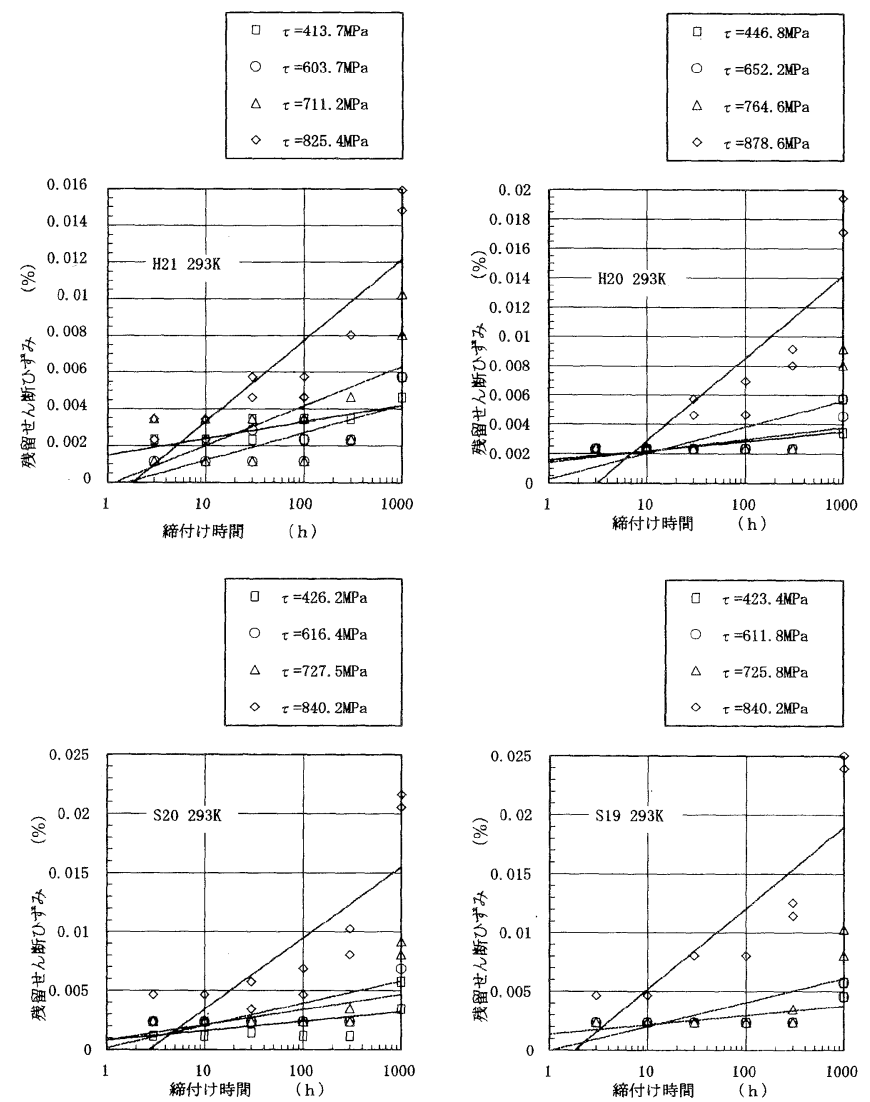

付図 21 残留せん断ひずみと締付け時間の関係 (3 次材, $293 \mathrm{~K}$, 応力修正係数なし)
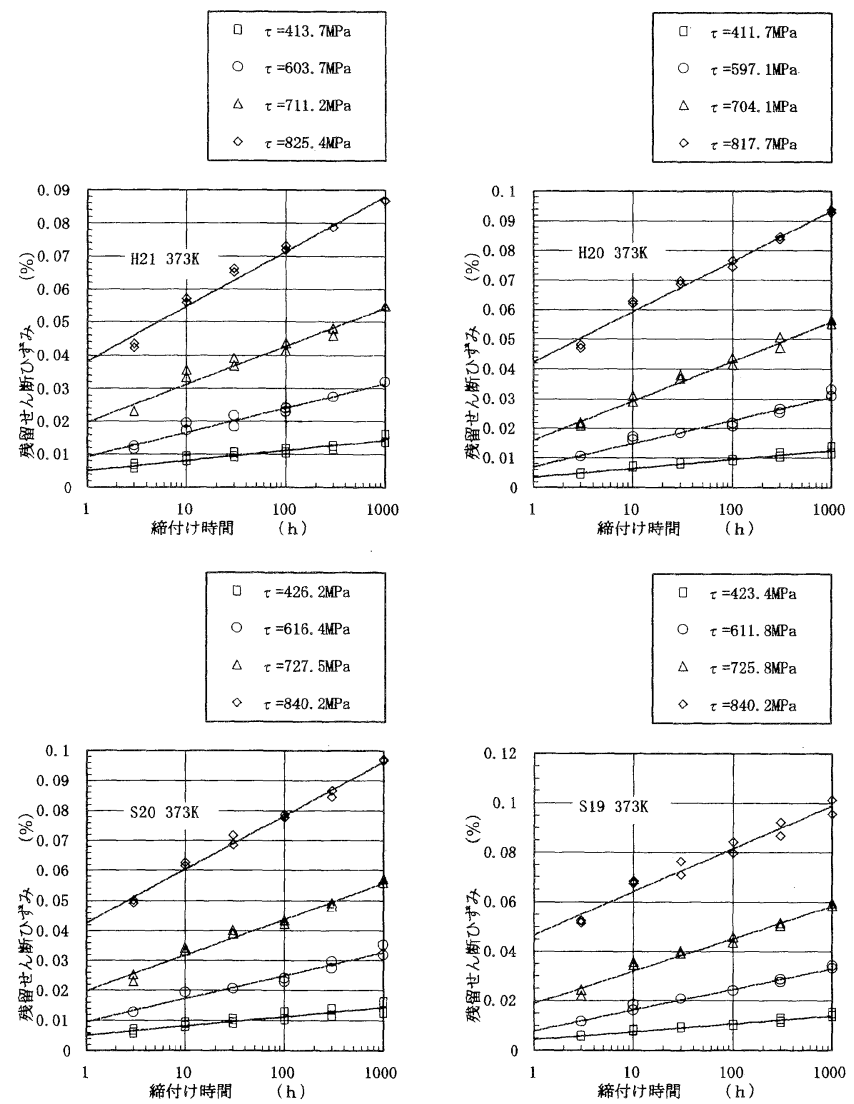

付図 22 残留せん断ひずみと締付け時間の関係 (3 次材, $373 \mathrm{~K}$, 応力修正係数なし)
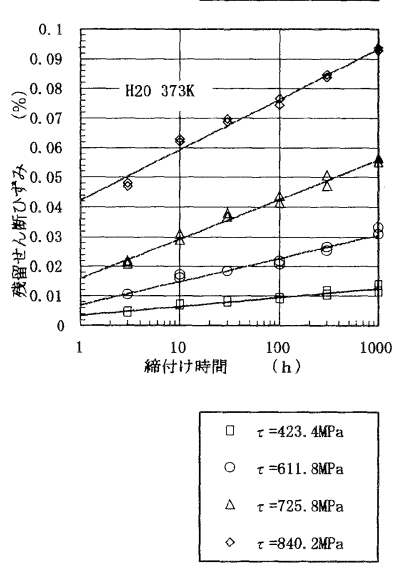
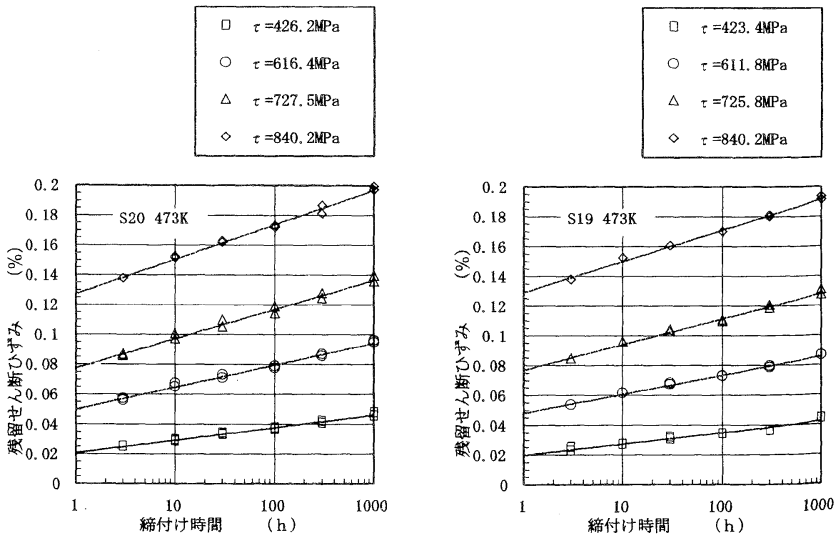

付図 23 残留せん断ひずみと締付け時間の関係 (3 次材, $473 \mathrm{~K}$, 応力修正係数なし) 